\title{
Different methods of external fixation for treating distal radial fractures in adults (Review)
}

\author{
Handoll HHG, Huntley JS, Madhok R
}

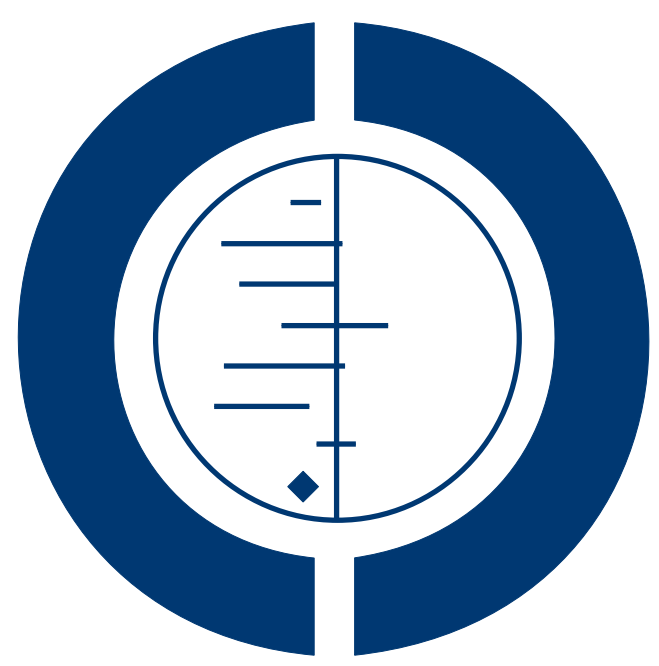

\section{THE COCHRANE COLLABORATION $^{\circledR}$}

This is a reprint of a Cochrane review, prepared and maintained by The Cochrane Collaboration and published in The Cochrane Library 2008, Issue 4

http://www.thecochranelibrary.com

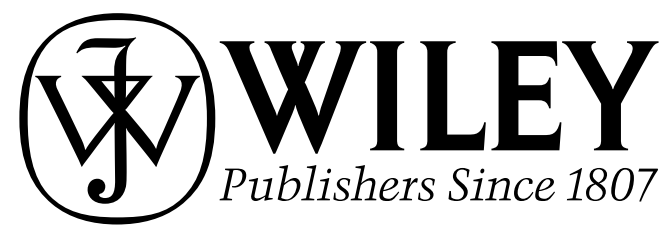

Different methods of external fixation for treating distal radial fractures in adults (Review)

Copyright (C) 2008 The Cochrane Collaboration. Published by John Wiley \& Sons, Ltd. 
TABLE OF CONTENTS

HEADER . . . . . . . . . . . . . . . . . . . . . . . . . . . . . . . . 1

ABSTRACT . . . . . . . . . . . . . . . . . . . . . . . . . . . . . . . . . . . . . . . . . . . . . . . . .

PLAIN LANGUAGE SUMMARY . . . . . . . . . . . . . . . . . . . . . . . . . . . . . . . . . . . . . 2

BACKGROUND . . . . . . . . . . . . . . . . . . . . . . . . . . . . . . . . . . . . . 3

OBJECTIVES . . . . . . . . . . . . . . . . . . . . . . . . . . . . . . . . . . . . . . . 5

METHODS . . . . . . . . . . . . . . . . . . . . . . . . . . . . . . . . . . . . 5

RESULTS . . . . . . . . . . . . . . . . . . . . . . . . . . . . . . . . . . . . . . . 11

DISCUSSION . . . . . . . . . . . . . . . . . . . . . . . . . . . . . . . . . . . . . 20

AUTHORS' CONCLUSIONS . . . . . . . . . . . . . . . . . . . . . . . . . . . . . . . . . . . . . . . 23

ACKNOWLEDGEMENTS . . . . . . . . . . . . . . . . . . . . . . . . . . . . . . . . 24

REFERENCES . . . . . . . . . . . . . . . . . . . . . . . . . . . . . . . . . . . . . . . . 24

CHARACTERISTICS OF STUDIES . . . . . . . . . . . . . . . . . . . . . . . . . . . . . . . . . . . . . . . $\quad . \quad 27$

DATA AND ANALYSES . . . . . . . . . . . . . . . . . . . . . . . . . . . . . . . . . . 40

Analysis 1.1. Comparison 1 External fixator versus pins and plaster external fixation, Outcome 1 Functional grading: fair (or poor). . . . . . . . . . . . . . . . . . . . . . . . . . . . . . . . . . . .

Analysis 1.2. Comparison 1 External fixator versus pins and plaster external fixation, Outcome 2 Subjective assessment of function.

Analysis 1.3. Comparison 1 External fixator versus pins and plaster external fixation, Outcome 3 Grip strength (\% or normal side).

Analysis 1.4. Comparison 1 External fixator versus pins and plaster external fixation, Outcome 4 Complications.

Analysis 1.5. Comparison 1 External fixator versus pins and plaster external fixation, Outcome 5 Patient dissatisfaction with outcome.

Analysis 1.6. Comparison 1 External fixator versus pins and plaster external fixation, Outcome 6 Anatomical grading: fair or poor. . . . . . . . . . . . . . . . . . . . . . . . . . . . . . . . . . . . .

Analysis 2.1. Comparison 2 Non-bridging versus bridging external fixation, Outcome 1 DASH scores (0 to 100: most disability).

Analysis 2.2. Comparison 2 Non-bridging versus bridging external fixation, Outcome 2 SF-12 physical domain scores (0 onwards; higher better: population mean $=50$ ).

Analysis 2.3. Comparison 2 Non-bridging versus bridging external fixation, Outcome 3 Grip strength (kg). . . . .

Analysis 2.4. Comparison 2 Non-bridging versus bridging external fixation, Outcome 4 Mass grip strength (\% of normal side). . . . . . . . . . . . . . . . . . . . . . . . . . . . . . . . . . . . . .

Analysis 2.5. Comparison 2 Non-bridging versus bridging external fixation, Outcome 5 Residual pain. . . . . . . 50

Analysis 2.6. Comparison 2 Non-bridging versus bridging external fixation, Outcome 6 Pain (VAS 0 to 100: worst). 50

Analysis 2.7. Comparison 2 Non-bridging versus bridging external fixation, Outcome 7 Range of motion (degrees). . 51

Analysis 2.8. Comparison 2 Non-bridging versus bridging external fixation, Outcome 8 Range of motion (\% of normal side).

Analysis 2.9. Comparison 2 Non-bridging versus bridging external fixation, Outcome 9 Complications. . . . . .

Analysis 2.10. Comparison 2 Non-bridging versus bridging external fixation, Outcome 10 Patient dissatisfaction with outcome.

Analysis 2.11. Comparison 2 Non-bridging versus bridging external fixation, Outcome 11 Anatomical displacement.

Analysis 2.12. Comparison 2 Non-bridging versus bridging external fixation, Outcome 12 Anatomical measurements.

Analysis 2.13. Comparison 2 Non-bridging versus bridging external fixation, Outcome 13 Deformity (structural).

Analysis 2.14. Comparison 2 Non-bridging versus bridging external fixation, Outcome 14 Length of surgery (minutes).

Analysis 3.1. Comparison 3 Supplementary percutanous pinning of distal radial fracture fragment, Outcome 1 Functional gradings.

Analysis 3.2. Comparison 3 Supplementary percutanous pinning of distal radial fracture fragment, Outcome 2 Grip strength $(\%$ of normal side). . . . . . . . . . . . . . . . . . . . . . . . . . . . . .

Analysis 3.3. Comparison 3 Supplementary percutanous pinning of distal radial fracture fragment, Outcome 3 Range of motion (\% of normal side). . . . . . . . . . . . . . . . . . . . . . . . . . . . . . . . . . .

Analysis 3.4. Comparison 3 Supplementary percutanous pinning of distal radial fracture fragment, Outcome 4 Complications. 
Analysis 3.5. Comparison 3 Supplementary percutanous pinning of distal radial fracture fragment, Outcome 5 Ulnar plus variance.

Analysis 3.6. Comparison 3 Supplementary percutanous pinning of distal radial fracture fragment, Outcome 6 Length of surgery (minutes). . . . . . . . . . . . . . . . . . . . . . . . . . . . . . . . .

Analysis 4.1. Comparison 4 Hydroxyapatite coated versus standard pins, Outcome 1 Complications. . . . . . . .

Analysis 4.2. Comparison 4 Hydroxyapatite coated versus standard pins, Outcome 2 Torque for insertion and removal of pins $(\mathrm{Nmm})$.

Analysis 5.1. Comparison 5 Dynamic versus static fixation, Outcome 1 Functional gradings. . . . . . . . . . .

Analysis 5.2. Comparison 5 Dynamic versus static fixation, Outcome 2 Mass grip strength (\% of normal side). . .

Analysis 5.3. Comparison 5 Dynamic versus static fixation, Outcome 3 Range of movement (\% of normal side). . .

Analysis 5.4. Comparison 5 Dynamic versus static fixation, Outcome 4 Complications. . . . . . . . . . . . .

Analysis 5.5. Comparison 5 Dynamic versus static fixation, Outcome 5 Anatomical displacement. . . . . . . . .

Analysis 5.6. Comparison 5 Dynamic versus static fixation, Outcome 6 Anatomical measurements. . . . . . . .

Analysis 5.7. Comparison 5 Dynamic versus static fixation, Outcome 7 Deformity (structural). . . . . . . . .

APPENDICES . . . . . . . . . . . . . . . . . . . . . . . . . . . . . .

WHAT'S NEW . . . . . . . . . . . . . . . . . . . . . . . . . . . . . . . . . . . . . .

HISTORY . . . . . . . . . . . . . . . . . . . . . . . . . . . . . . . . . . . . . . .

CONTRIBUTIONS OF AUTHORS . . . . . . . . . . . . . . . . . . . . . . . . . . . . . . . . . . . . . . .

DECLARATIONS OF INTEREST . . . . . . . . . . . . . . . . . . . . . . . . . . . . . .

SOURCES OF SUPPORT . . . . . . . . . . . . . . . . . . . . . . . . . . . . . . . . . . . . . . . . . . .

NOTES . . . . . . . . . . . . . . . . . . . . . . . . . . . . . . . . . . . . . . . .

INDEX TERMS 


\title{
[Intervention Review]
}

\section{Different methods of external fixation for treating distal radial fractures in adults}

\author{
Helen HG Handoll ${ }^{1}$, James S Huntley ${ }^{2}$, Rajan Madhok $^{3}$ \\ ${ }^{1}$ Centre for Rehabilitation Sciences (CRS), Research Institute for Health Sciences and Social Care, University of Teesside, Middlesbor- \\ ough, UK. ${ }^{2}$ University Department of Orthopaedic Surgery, Royal Infirmary of Edinburgh, Edinburgh, UK. ${ }^{3}$ Cochrane Bone, Joint \\ and Muscle Trauma Group, University of Manchester, Manchester, UK \\ Contact address: Helen HG Handoll, Centre for Rehabilitation Sciences (CRS), Research Institute for Health Sciences and Social \\ Care, University of Teesside, School of Health and Social Care, Middlesborough, Tees Valley, TS1 3BA, UK. h.handoll@tees.ac.uk. \\ H.Handoll@ed.ac.uk.
}

Editorial group: Cochrane Bone, Joint and Muscle Trauma Group.

Publication status and date: Edited (no change to conclusions), published in Issue 4, 2008.

Review content assessed as up-to-date: 1 October 2007.

Citation: Handoll HHG, Huntley JS, Madhok R. Different methods of external fixation for treating distal radial fractures in adults. Cochrane Database of Systematic Reviews 2008, Issue 1. Art. No.: CD006522. DOI: 10.1002/14651858.CD006522.pub2.

Copyright (C) 2008 The Cochrane Collaboration. Published by John Wiley \& Sons, Ltd.

\section{A B S T R A C T}

\section{Background}

Fracture of the distal radius is a common injury. A surgical treatment is external fixation, where metal pins inserted into bone on either side of the fracture are then fixed to an external frame.

\section{Objectives}

To evaluate the evidence from randomised controlled trials comparing different methods of external fixation for distal radial fractures in adults.

\section{Search strategy}

We searched the Cochrane Bone, Joint and Muscle Trauma Group Specialised Register (June 2007), the Cochrane Central Register of Controlled Trials, MEDLINE, EMBASE and other databases, conference proceedings and reference lists of articles. No language restrictions were applied.

\section{Selection criteria}

Randomised or quasi-randomised controlled clinical trials which compared different methods of external fixation in adults with a distal radial fracture.

Data collection and analysis

All review authors independently performed study selection. Two authors independently assessed the included trials and performed data extraction.

\section{Main results}

Nine small trials involving 510 adults with potentially or evidently unstable fractures, were grouped into five comparisons. The interventional, clinical and methodological heterogeneity of trials precluded data pooling. Only one trial had secure allocation concealment. 
Two trials comparing a bridging (of the wrist) external fixator versus pins and plaster external fixation found no significant differences in function or deformity. One trial found tendencies for more serious complications but less subsequent discomfort and deformity in the fixator group.

Three trials compared non-bridging versus bridging fixation. Of the two trials testing uni-planar non-bridging fixation, one found no significant differences in functional or clinical outcomes; the other found non-bridging fixation significantly improved grip strength, wrist flexion and anatomical outcome. The third trial found no significant findings in favour of multi-planar non-bridging fixation of complex intra-articular fractures.

One trial using a bridging external fixator found that deploying an extra external fixator pin to fix the 'floating' distal fragment gave superior functional and anatomical results.

One trial found no evidence of differences in clinical outcomes for hydroxyapatite coated pins compared with standard uncoated pins.

Two trials compared dynamic versus static external fixation. One trial found no significant effects from early dynamism of an external fixator. The poor quality of the other trial undermines its findings of poorer functional and anatomical outcomes for dynamic fixation.

\section{Authors' conclusions}

There is insufficient robust evidence to determine the relative effects of different methods of external fixation. Adequately powered studies could provide better evidence.

\section{PLAIN LANGUAGE SUMMARY}

\section{Different methods of external fixation for treating distal radial fractures in adults}

In older people, a 'broken wrist' (from a fracture at the lower end of the two forearm bones) can result from a fall onto an outstretched hand. Surgery may be considered for more seriously displaced fractures. One type of surgery is external fixation, in which metal pins are driven into bone on either side of the fracture via small skin incisions and fixed externally. The external component holds the bony fragments in position while the bone heals. Most of the differences between methods of external fixation are a) in the characteristics and design of the external component and b) in the placement of pins. In some cases, the distal pins are placed into bones of the hand rather than the generally more fragile end of the fractured bone. This is bridging fixation, where the external component bridges and immobilises the wrist joint.

This review looked at the evidence from randomised controlled trials comparing different methods of external fixation.

Nine small randomised trials involving 510 adults with potentially or evidently unstable fractures, were grouped into five comparisons. The trials were too different to justify pooling of results. Only one trial used a best-practice method for preventing selection bias.

Two trials comparing a bridging (of the wrist) external fixator versus pins and plaster external fixation found no statistically significant differences in function or deformity. One trial found tendencies for more serious complications but less subsequent discomfort and deformity in the fixator group.

Three trials compared non-bridging versus bridging fixation, using external fixators. Two trials tested similar non-bridging fixators: one found no significant differences in functional or clinical outcomes, whereas the other found non-bridging fixation significantly improved grip strength, wrist flexion and anatomical outcome. The third trial found no significant findings in favour of multi-planar non-bridging fixation of complex fractures.

One trial using a bridging external fixator found that fixing the distal fracture fragment with an extra external fixator pin gave superior functional and anatomical results.

One trial found no evidence of differences in clinical outcomes for hydroxyapatite coated pins compared with standard uncoated pins.

Two trials compared dynamic versus static external fixation. One trial found no significant effects from the early 'dynamism' of an external fixator. The poor quality of the other trial undermines its findings of poorer results for dynamic fixation.

The review concluded that there is insufficient robust evidence to determine the relative effects of the different methods of external fixation.

Different methods of external fixation for treating distal radial fractures in adults (Review)

Copyright (@) 2008 The Cochrane Collaboration. Published by John Wiley \& Sons, Ltd. 


\section{B A C K G R O U N D}

Note: This is one of five reviews that will cover all surgical interventions for treating distal radial fractures in adults. Each review will provide updated evidence for one of the several surgical categories that are presented together in the currently available review (Handoll 2003a). Following publication of the five reviews, Handoll 2003a will be converted to an 'umbrella' review summarising the evidence for surgical treatment for these fractures.

\section{Description of the condition: distal radial fracture in adults}

Fractures of the distal radius, often referred to as "wrist fractures", occur in both children and adults. They are usually defined as occurring in the distal radius within three centimetres of the radiocarpal joint, where the lower end of the radius articulates with two (the lunate and the scaphoid) of the eight bones forming the carpus (the wrist). The majority are closed injuries, the overlying skin remaining intact.

In this review, we consider the treatment of distal radial fracture in adults only, in whom they are one of the most common fractures, predominantly in white and older populations in the developed world (Sahlin 1990; Singer 1998; Van Staa 2001). In women, the incidence of these fractures increases with age, and between 60 to 94 years of age, females predominate. Before 40 years, the incidence is higher in men (Singer 1998). A recent multi-centre study in the United Kingdom of patients aged 35 years and above with Colles' fracture (see below) reported an annual incidence of 9/10,000 in men and 37/10,000 in women (O’Neill 2001).

Young adults usually sustain this injury as a result of high-energy trauma, such as a traffic accident. In older adults, especially females, the fracture more often results from low-energy or moderate trauma, such as falling from standing height. This reflects the greater fragility of the bone, resulting from osteoporosis. It has been estimated that, at 50 years of age, a white woman in USA or Northern Europe has a $15 \%$ lifetime risk of a distal radius fracture whereas a man has a lifetime risk of just over two per cent ( Cummings 1985). More recent estimates (Van Staa 2001) of lifetime risk of radius or ulna fracture at 50 years of age are similar: $16.6 \%$ for women versus $2.9 \%$ for men.
Distal radial fractures are usually treated on an outpatient basis. It is estimated that around $20 \%$ of patients (mainly older people) require hospital admission (Cummings 1985; O'Neill 2001). This figure includes all people receiving surgery.

\section{Classification}

Surgeons have classified fractures by anatomical configuration and fracture pattern, to help in their management. Simple classifications were based on clinical appearance and often named after those who described them. In the distal radius, the term "Colles' fracture" is still used for a fracture in which there is an obvious and typical clinical appearance (commonly referred to as a 'dinner fork deformity') - reflecting dorsal displacement, dorsal angulation, dorsal comminution, and radial shortening. The introduction of X-rays and other imaging methods made it clear that the characteristic deformity may be associated with a range of different fracture patterns, which may be important determinants of outcome, and therefore the way in which the injury is treated. For example, the fracture through the distal radius may be extra-articular (leaving the articular or joint surface of the radius intact) or intra-articular (the articular surface is disrupted). Numerous classifications have been devised to define and group different fracture patterns (Chitnavis 1999). Brief descriptions of five commonly cited classification systems are presented in Table 1 (Cooney 1993; Frykman 1967; Melone 1993; Muller 1991; Older 1965).

\section{Description of the intervention: external fixation}

In the last century, most distal radial fractures in adults were treated conservatively, by reduction of the fracture if displaced, and stabilisation in a plaster cast or other external brace. The results of such treatment, particularly in older people with bones weakened by osteoporosis, are not consistently satisfactory (Handoll 2003b). This has resulted in attempts to develop other strategies involving surgery aimed at more accurate reduction and more reliable stabilisation.

Table 1. Commonly used classification systems

\begin{tabular}{|c|c|c|}
\hline Name (reference ID) & Brief outline & Comment \\
\hline $\begin{array}{l}\text { AO (Arbeitsgemeinschaft fur Osteosynthe- } \\
\text { sefragen)(Muller 1991) }\end{array}$ & $\begin{array}{l}\text { This system is organised in order of increas- } \\
\text { ing fracture severity. It divides the fractures } \\
\text { into three major groups: group A (extra-ar- } \\
\text { ticular), group B (simple/partial intra-artic- } \\
\text { ular), and group C (complex/complete in- } \\
\text { tra-articular). These three groups are then } \\
\text { subdivided, yielding } 27 \text { different fracture } \\
\text { types. }\end{array}$ & $\begin{array}{l}\text { There is no assessment of the extent of frac- } \\
\text { ture displacement. }\end{array}$ \\
\hline
\end{tabular}




Frykman
(Frykman 1967) $\begin{aligned} & \text { This system distinguishes between extra- } \\ & \text { articular fractures and intra-articular frac- } \\ & \text { tures of the radiocarpal and radio-ulnar } \\ & \text { joints, and the presence or absence of an } \\ & \text { associated distal ulnar (ulnar styloid) frac- } \\ & \text { ture. There are } 8 \text { types labelled I to VIII (1 } \\ & \text { to } 8 \text { ): the higher the number, the greater } \\ & \text { complexity of the fracture. }\end{aligned}$

Melone

(Melone 1993)

Older

(Older 1965)
There is no assessment of the extent or direction of fracture displacement, or of comminution.
This system identifies 5 fracture types, This is for intra-articular fractures only. based on 4 major fracture components: the radial shaft, the radial styloid, and the dorsal-medial and volar-medial fragments.

ity. The types are defined according to ex-
tent of displacement (angulation and radial
shortening)and comminution.

'Universal Classification' (Cooney 1993)
This system divides fractures into 4 main types, labelled I to VI (1 to 4 ), distinguishing between extra-articular and intra-articular fractures and displaced and non-displaced fractures. Displaced fracture types II and IV are further subdivided based on reducibility (whether the fracture can be reduced; that is whether the bone fragments can be put back in place) and stability (whether, once reduced, the fragments will remain so).
One such strategy is external fixation (Capo 2006; Fernandez 1999; Pennig 1996). Typically this is a closed, minimally invasive method in which, in contrast to open surgery, the fractured bone is not exposed to direct view. Metal pins or screws are driven into bone, generally via small incisions in the skin and after drilling, on either side of the fracture. These pins are then fixed externally, such as by incorporation into a plaster cast or the frame of an external fixator. The external component stabilises or 'fixes' the reduced fracture. Fracture reduction (the alignment of the bony fragments) is generally achieved by closed means, often in the process of applying external fixation. Reduction may be assisted by the application of a percutaneously (through the skin) inserted wire as a 'joy stick' to move the bony fragments back into place. There is considerable variety in the techniques (such as for pin insertion and placement) and devices used for external fixation. Some devices are 'non-bridging' (of the wrist joint) in that the distal pins are placed in the distal radial fragment leaving the radiocarpal joint free to move. In 'bridging fixators', the distal pins are placed in one or more metacarpal bones. Some fixators are linear or uniplanar, whereas others are multiplanar. In addition, some bridging fixators have an articulation (e.g. a ball joint) that allows limited wrist movement. The duration and extent of immobilisation with external fixation also vary.

In some cases, external fixation may be augmented by additional methods of fracture fixation. In this review, we will include only 
trials using supplementary percutaneous pinning. This involves extra pins or wires being inserted through the skin and used to fix or support distal radial fragments.

\section{Complications}

Complications from this injury are diverse and frequent (Altissimi 1986; Atkins 1989; Cooney 1980). Some are associated with the injury itself. As well as concomitant injuries to soft tissues, fracture displacement can further compromise blood vessels, tendons and nerves, with median nerve dysfunction being the most common complication (Belsole 1993). Late complications include midcarpal instability (dynamic instability resulting from malaligned bones in the midcarpal joint (within the wrist) that is associated with pain, decreased grip strength and clicking) and post-traumatic arthritis which can occur several months or years after injury (Knirk 1986; Taleisnik 1984).

Complications can also result from treatment interventions and include residual finger stiffness, which may be due to faulty application of plaster casts (Gartland 1951), pin track infection, soft tissue injury including tendon rupture, and additional fractures from external fixation. Complex regional pain syndrome type 1, still referred to as reflex sympathetic dystrophy (RSD), algodystrophy, Sudeck's atrophy and shoulder-hand syndrome (Fernandez 1996), is a major complication (Atkins 2004) requiring many months of physiotherapy to alleviate symptoms (pain and tenderness, impairment of joint mobility, swelling, dystrophy, vasomotor instability) in serious cases. The etiology and pathology of RSD are often unclear.

\section{Why it is important to do this review?}

External fixation is one of the main methods for surgical fixation of distal radial fractures. The key question of whether it produces superior results to conservative treatment is addressed in another review (Handoll 2007). Meanwhile, this review examines what is the best method of external fixation. The answers to both these questions are likely to depend on fracture configuration and bone quality.

\section{O B J E C T I VES}

We aimed to evaluate the evidence from randomised controlled trials comparing the relative effects (benefits and harms) of different methods of external fixation for fractures of the distal radius in skeletally mature people. Studies evaluating augmented external fixation where supplementary percutaneous (through the skin) pinning was used to fix or support distal radial fragments were also included.

We considered these effects primarily in terms of patient-assessed functional outcome and satisfaction, and other measures of function and impairment, pain and discomfort, the incidence of complications, anatomical deformity and use of resources.
Our plan to study the outcomes in different age groups and for different fracture types, especially whether they are extra-articular or intra-articular, was thwarted by the lack of data and variation in the trial characteristics.

\section{METHODS}

\section{Criteria for considering studies for this review}

\section{Types of studies}

We considered all randomised or quasi-randomised (method of allocating participants to a treatment which is not strictly random e.g. by date of birth, hospital record number, alternation) controlled clinical trials comparing different methods of external fixation for treating distal radial fractures in adults.

\section{Types of participants}

Patients of either sex with a fracture of the distal radius, who had completed skeletal growth were included. External fixation may be used as primary treatment or else secondary treatment after the failure of initial conservative management, generally within two to three weeks. Augmented external fixation in the form of supplementary percutaneous pinning was also included. Trials with a mixed population of adults and children were included, provided the proportion of children was clearly small $(<5 \%)$. Otherwise these would have been excluded unless separate data for adults were obtained. We considered it unlikely that we would find trials comparing different methods of external fixation with conservative treatment for fracture patterns such as the Barton's fractures (Smith 1988) that are inherently unstable and generally considered not to be amenable to external fixation. Nonetheless, a trial ( Hutchinson 1995) with two Barton's fractures among 90 unstable fractures was included. Given the small number of Barton's fractures and the large variety of fracture types in this trial we did not seek separate subgroup data for different fracture types.

\section{Types of interventions}

Randomised comparisons of different methods of external fixation, including augmentation with supplementary percutaneous pinning, for treating fractures of the distal radius in adults. This includes comparisons of:

- primary methods (external fixator versus pins and plaster external fixation; and non-bridged versus bridged (over wrist joint) external fixation);

- augmented external fixation involving supplementary percutaneous pinning versus external fixation alone;

- different subsidiary components of surgical technique (different methods of reduction of the fracture fragments; different methods of pin insertion; use and type of imaging 
modalities (e.g. X-ray fluoroscopy) for monitoring the reduction and operation; different types of supplementary percutaneous pinning);

- different types of fixation devices (different types and coatings of external fixator pins; uniplanar versus multiplanar external fixators; recycled versus new external fixators);

- different types or duration of post-operative immobilisation (including dynamic versus static external fixation).

We excluded trials comparing external fixation with conservative treatment (see Handoll 2007) or with other methods of surgical fixation, such as percutaneous pinning. We also excluded trials evaluating the use of supplementary methods, such as bone grafts and substitutes, other than percutaneous pinning, to external fixation. These comparisons will be covered in other reviews, including one covering the use of bone grafts and substitutes. We also excluded trials on pin site maintenance or other measures to prevent wound infection (already covered in Temple 2004).

\section{Types of outcome measures}

Our primary outcome of choice is the number of people with an uncomplicated and speedy restoration of a pain-free fully-functioning wrist and arm with acceptable anatomic restoration and appearance. However, compatible with the general assessment and presentation of outcome within the orthopaedic literature, we report outcome in the following four categories.

\section{Primary outcomes}

\section{(1) Functional outcome and impairment}

- Patient functional assessment instruments such as Short Form-36 (SF-36), the Disability of the Arm, Shoulder, and
Hand questionnaire (DASH) and the Patient-Rated Wrist Evaluation (PRWE) (MacDermid 2000)

- Return to previous occupation, including work, and activities of daily living

- Grip strength

- Pain

- Range of movement (wrist and forearm mobility): range of movement for the wrist is described in terms of six parameters: flexion (ability to bend the wrist downwards) and extension (or upwards); radial deviation (ability to bend the wrist sideways on the thumb side) and ulnar deviation (on the little finger side); and pronation (ability to turn the forearm so that the palm faces downwards) and supination (palm faces upwards)

\section{(2) Clinical outcome}

- Residual soft tissue swelling

- Early and late complications associated with distal radial fractures or their treatment, including reflex sympathetic dystrophy (RSD) and post traumatic osteoarthritis

- Cosmetic appearance

- Patient satisfaction with treatment

\section{Secondary outcomes}

\section{(3) Anatomical outcome (anatomical restoration and residual deformity)}

- Radiological parameters include radial length or shortening and shift, dorsal angulation, radial inclination or angle, ulnar variance, and for intra-articular fractures: step off and gap deformity of the articular surface (Fernandez 1996; Kreder 1996a). Composite measures include malunion and total radiological deformity. Definitions of four of the most commonly reported radiological parameters are presented in Table 2 .

Table 2. Definitions of key radiological parameters

\begin{tabular}{|c|c|c|}
\hline Parameter & Definition & Normal value \\
\hline $\begin{array}{l}\text { Dorsal angulation (dorsal or volar or pal- } \\
\text { mar tilt) }\end{array}$ & $\begin{array}{l}\text { Angle between a) the line which connects } \\
\text { the most distal points of the dorsal and } \\
\text { volar cortical rims of the radius and b) the } \\
\text { line drawn perpendicular to the longitudi- } \\
\text { nal axis of the radius. Side view of wrist. }\end{array}$ & $\begin{array}{l}\text { Palmar or volar tilt: approximately 11-12 } \\
\text { degrees. }\end{array}$ \\
\hline Radial length & $\begin{array}{l}\text { Distance between a) a line drawn at the tip } \\
\text { of the radial styloid process, perpendicular } \\
\text { to the longitudinal axis of the radius and } \\
\text { b) a second perpendicular line at the level } \\
\text { of the distal articular surface of the ulnar } \\
\text { head. Frontal view. }\end{array}$ & Approximately 11-12 mm. \\
\hline
\end{tabular}


Table 2. Definitions of key radiological parameters (Continued)

\begin{tabular}{l|l}
\hline Radial angle or radial inclination & $\begin{array}{l}\text { Angle between a) the line drawn from the Approximately 22-23 degrees. } \\
\text { tip of the radial styloid process to the ulnar } \\
\text { corner of the articular surface of the distal } \\
\text { end of the radius and b) the line drawn } \\
\text { perpendicular to the longitudinal axis of } \\
\text { the radius. Frontal view. }\end{array}$ \\
\hline Ulnar variance & $\begin{array}{l}\text { Vertical distance between a) a line drawn Usually negative variance (e.g. -1 mm) or } \\
\text { parallel to the proximal surface of the lu- neutral variance. } \\
\text { nate facet of the distal radius and b) a line } \\
\text { parallel to the articular surface of the ulnar } \\
\text { head. }\end{array}$ \\
\hline
\end{tabular}

\section{(4) Resource use}

- Hospital stay, number of outpatient attendances, physiotherapy and other costs.

\section{Comparison specific outcomes}

For some comparisons, such as those of different techniques used for external fixation, outcomes other than those listed above may be relevant and reported. Such outcomes, namely length of surgery, were presented in the analyses.

\section{Timing of outcome assessment}

Results were usually collected for the final follow-up time for which these are available. However, we also planned to note interim results where a marked and important difference in the timing of recovery had occurred.

\section{Search methods for identification of studies}

\section{Electronic searches}

We searched the Cochrane Bone, Joint and Muscle Trauma Group Specialised Register (June 2007), the Cochrane Central Register of Controlled Trials (in The Cochrane Library 2007, Issue 2) (see Appendix 1), MEDLINE (1996 to June week 1 2007), EMBASE (1988 to 2007 week 22), CINAHL (1982 to June week 1 2007). No language restrictions were applied.

In MEDLINE (OVID-WEB) the following search strategy was combined with all three sections of the optimal MEDLINE search strategy for randomised trials (Higgins 2005) (see Appendix 2).
Similar search strategies were used for EMBASE (OVID-WEB) and CINAHL (OVID-WEB) (see Appendix 2).

We also searched Current Controlled Trials at www.controlledtrials.com (accessed June 2007) and the UK National Research Register at www.update-software.com/national/ (up to Issue 2, 2007) for ongoing and recently completed trials.

\section{Searching other resources}

We searched reference lists of articles. We also included the findings from handsearches of the British Volume of the Journal of Bone and Joint Surgery supplements (1996 onwards) and abstracts of the American Society for Surgery of the Hand annual meetings (2000 to 2006: www.assh.org/), the American Orthopaedic Trauma Association annual meetings (1996 to 2006: www.hwbf.org/ota/am/) and American Academy of Orthopaedic Surgeons annual meeting (2004 to 2007: www.aaos.org/wordhtml/libscip.htm). We also included handsearch results from the final programmes of SICOT (1996 \& 1999) and SICOT/SIROT (2003), EFFORT (2007) and the British Orthopaedic Association Congress (2000, 2001, 2002, 2003, 2005 and 2006), and various issues of Orthopaedic Transactions and of Acta Orthopaedica Scandinavica Supplementum.

We also scrutinised weekly downloads of "Fracture" articles in new issues of 15 journals (Acta Orthop Scand; Am J Orthop; Arch Orthop Trauma Surg; Clin J Sport Med; Clin Orthop; Foot Ankle Int; Injury; J Am Acad Orthop Surg; J Arthroplasty; J Bone Joint Surg Am; J Bone Joint Surg Br; J Foot Ankle Surg; J Orthop Trauma; J Trauma; Orthopedics) from AMEDEO (www.amedeo.com).

\section{Data collection and analysis}




\section{Selection of studies}

All review authors independently assessed potentially eligible trials for inclusion using a pre-piloted form. Any disagreement was resolved by discussion.

\section{Data extraction and management}

Using a data extraction form, two of the review authors ( $\mathrm{HH}$ and $\mathrm{JH}$ ) independently extracted trial details and data for new trials, and one author $(\mathrm{HH})$ repeated data extraction of trials already included in Handoll 2003a and checked for consistency with her previous data extraction. $\mathrm{HH}$ entered the data into RevMan. Any disagreements were resolved by discussion. When appropriate, extraction of results from graphs in trial reports was performed where data were not provided in the text or tables. We contacted trialists of trials not reported in full journal publications for additional information or data. Contact with other trial authors was dictated by the vintage of the publication, a general impression of the expected gain, and anticipated or known difficulty in locating trial authors.

Results were collected for the final follow-up time for which these were available. We also noted instances where clinically important differences had been reported at intermediate follow-up assessments.

\section{Assessment of methodological quality}

In this review, risk of bias is implicitly assessed in terms of methodological quality

Two of the review authors ( $\mathrm{HH}$ and $\mathrm{JH}$ ) independently assessed methodological quality of the newly included trials using a prepiloted form. One author $(\mathrm{HH})$ repeated her assessment of the trials already included in Handoll 2003a. All disagreements were resolved by discussion. Titles of journals, names of authors or supporting institutions were not masked at any stage. A modification of the quality assessment tool used in the current 'umbrella' review was used. Instead of scores, each item was graded based on whether the quality criterion was met: 'Y' (met), '?' (possibly or only partially met) or ' $\mathrm{N}$ ' (not met). The rating scheme covering 11 aspects of trial validity plus brief notes of coding guidelines for selected items are given in Table 3.

Table 3. Methodological quality assessment scheme

\begin{tabular}{l|l|l}
\hline Items & Grades & Notes \\
\hline (1) Was the assigned treatment adequately & $\mathrm{Y}=$ method did not allow disclosure of as- & Cochrane code (see Handbook): Clearly \\
signment. & $\begin{array}{l}\text { ? = small but possible chance of disclosure } \\
\text { of assignment or unclear. } \\
\text { concealed prior to allocation? }\end{array}$ & $\begin{array}{l}\mathrm{N}=\text { quasi-randomised, or open list or ta- } \\
\text { bles. }\end{array}$ \\
\end{tabular}


(2) Were the outcomes of participants who $Y=$ withdrawals well described and acwithdrew described and included in the counted for in analysis. analysis (intention-to-treat)?

? = withdrawals described and analysis not possible, or probably no withdrawals.

$\mathrm{N}=$ no mention, inadequate mention, or obvious differences and no adjustment.

(3) Were the outcome assessors blinded to $Y=$ effective action taken to blind assessors. treatment status? ? = small or moderate chance of unblinding of assessors, or some blinding of outcomes attempted.

$\mathrm{N}=$ not mentioned or not possible.

(4) Were important baseline characteristics reported and comparable?
$\mathrm{Y}=$ good comparability of groups, or confounding adjusted for in analysis.

? = confounding small, mentioned but not adjusted for, or comparability reported in text without confirmatory data.

$\mathrm{N}=$ large potential for confounding, or not discussed.
Although many characteristics including hand dominance are important, the principal confounders are considered to be age, gender, type of fracture.

$\mathrm{Y}=$ effective action taken to blind participants.

$?=$ small or moderate chance of unblinding of participants.

$\mathrm{N}=$ not possible, or not mentioned (unless double-blind), or possible but not done.

(6) Were the treatment providers blind to assignment status?

$\mathrm{Y}=$ effective action taken to blind treatment providers.

$?=$ small or moderate chance of unblinding of treatment providers.

$\mathrm{N}=$ not possible, or not mentioned (unless double-blind), or possible but not done.

(7) Were care programmes, other than the $\mathrm{Y}=$ care programmes clearly identical. trial options, identical?
$?=$ clear but trivial differences, or some evidence of comparability.

$\mathrm{N}=$ not mentioned or clear and important differences in care programmes.
Examples of clinically important differences in other interventions are: time of intervention, duration of intervention, anaesthetic used within broad categories, operator experience, difference in rehabilitation.

(8) Were the inclusion and exclusion crite- $Y=$ clearly defined (including type of fracria for entry clearly defined? ture).

? = inadequately defined.

$\mathrm{N}=$ not defined.

(9) Were the outcome measures used clearly $\mathrm{Y}=$ clearly defined.

defined?

$?=$ inadequately defined.

$\mathrm{N}=$ not defined. 
Table 3. Methodological quality assessment scheme (Continued)

(10) Were the accuracy and precision, $Y=$ optimal.

with consideration of observer variation, of ?= adequate.

the outcome measures adequate; and were $\mathrm{N}=$ not defined, not adequate.

these clinically useful and did they include

active follow up?

(11) Was the timing (e.g. duration of $\mathrm{Y}=$ optimal. ( $>1$ year)

surveillance)clinically appropriate? ? = adequate. (6 months -1 year)

$\mathrm{N}=$ not defined, not adequate. $(<6$

months)

\section{Measures of treatment effect}

Where available, quantitative data, both dichotomous and continuous, for the outcome measures listed above (see 'Types of outcome measures') are presented in the analyses. Relative risks and 95\% confidence intervals were calculated for dichotomous outcomes and mean differences and 95\% confidence intervals were calculated for continuous outcomes.

\section{Unit of analysis issues}

The unit of randomisation in these trials is usually the individual patient. Exceptionally, as in the case of trials including people with bilateral fractures, data for trials may be presented for fractures or limbs rather than individual patients. This occurred to a very limited extent for two trials in this review: Hutchinson 1995 (one person with bilateral fractures: unidentified group) and Sommerkamp 1994 (one person with bilateral fractures in each group). Although appropriate corrections for unit of analysis and randomisation discrepancies were not made in these two trials, we present data for these trials because the disparity between the units of analysis and randomisation is small.

\section{Dealing with missing data}

Where possible, we performed intention-to-treat analyses to include all people randomised to the intervention groups. To a very limited extent, we have investigated the effect of drop outs and exclusions by conducting best and worst scenario analyses. We were alert to the potential mislabelling or non identification of standard errors for standard deviations. Unless missing standard deviations could be derived from confidence interval data, we did not assume values in order to present these in the analyses.

\section{Assessment of heterogeneity}

Had pooling been feasible, heterogeneity would have been assessed by visual inspection of the forest plot (analysis) along with consid- eration of the test for heterogeneity and the $\mathrm{I}^{2}$ statistic (Higgins 2003).

\section{Assessment of reporting biases}

There were insufficient data to assess publication bias; for example, by preparing a funnel plot.

\section{Data synthesis (meta-analysis)}

Given the clinical heterogeneity in the trials grouped in the same comparisons, we decided against pooling of the very few common outcomes. If we had pooled data, we planned to initially use the fixed-effect model and 95\% confidence intervals. Then, especially where there was unexplained heterogeneity, we would have considered using the random-effects model.

\section{Subgroup analysis and investigation of heterogeneity}

There were no data available to carry out our pre-specified subgroup analyses by age, gender and type of fracture (primarily, extra-articular versus intra-articular fractures). Presentation in separate subgroups was also considered where there was a fundamental difference in the timing of external fixation (primary treatment versus after the failure of initial conservative management). Again there were no data available. To test whether subgroups were statistically significantly different from one another, we proposed to test the interaction using the technique outlined by Altman and Bland (Altman 2003).

\section{Sensitivity analysis}

There were no data available to carry out our pre-specified sensitivity analyses examining various aspects of trial and review methodology, including the study quality (specifically allocation concealment, outcome assessor blinding and reportage of surgical experience), and inclusion of trials only reported in abstracts (all were full reports). 


\section{Interpretation of the evidence}

We graded the findings of the treatment comparisons according to the six categories of effectiveness used by contributors to Clinical

Evidence (BMJ 2006) (see Table 4) to assist our interpretation.

Table 4. Categories of effectiveness (definitions)

\begin{tabular}{l|l|l}
\hline Rank & Category & Definition \\
\hline 1 & Beneficial & $\begin{array}{l}\text { Interventions for which effectiveness has been demonstrated by clear evidence from } \\
\text { randomised controlled trials, and for which expectation of harms is small compared } \\
\text { with the benefits. }\end{array}$ \\
\hline 2 & Likely to be beneficial & $\begin{array}{l}\text { Interventions for which effectiveness is less well established than for those listed } \\
\text { under "beneficial". }\end{array}$ \\
\hline 3 & Trade off between benefits and harms & $\begin{array}{l}\text { Interventions for which clinicians and patients should weigh up the beneficial and } \\
\text { harmful effects according to individual circumstances and priorities. }\end{array}$ \\
\hline 4 & Unknown effectiveness & $\begin{array}{l}\text { Interventions for which there is currently insufficient data or data of inadequate } \\
\text { quality. }\end{array}$ \\
\hline 5 & Unlikely to be beneficial & $\begin{array}{l}\text { Interventions for which lack of effectiveness is less well established than for those } \\
\text { listed under "likely to be ineffective or harmful" }\end{array}$ \\
\hline 6 & Likely to be ineffective or harmful & $\begin{array}{l}\text { Interventions for which ineffectiveness or harmfulness has been demonstrated by } \\
\text { clear evidence. }\end{array}$ \\
\hline
\end{tabular}

Seven of the included trials were previously included in Handoll 2003a; this includes Werber 2003, whose study ID has been changed to reflect the identification of a full report. The two other trials (Atroshi 2006; Krishnan 2003) are new inclusions. Krishnan

\section{R E S U L T S}

\section{Description of studies}

See: Characteristics of included studies; Characteristics of excluded studies.

\section{Results of the search}

The search for trials predated the development of this review, which is essentially an update of part of a previously published review (Handoll 2003a) covering all surgical intervention for these fractures. We have not documented the numbers of references retrieved by electronic searches. Updates of MEDLINE, EMBASE and CINAHL are now generated on a weekly basis. Of 21 potentially eligible studies put forward for study selection, nine were included, eight were excluded and four remain in 'Studies awaiting assessment'.
2003 was pending assessment in Handoll 2003a.

\section{Included studies}

All of the included studies were fully reported in English language medical journals. Five included trials were initially located by handsearching. The rest were located in the following ways: The Cochrane Bone, Joint and Muscle Trauma Group Specialist Register (1); EMBASE (1); and MEDLINE (2).

Details of the methods, participants, interventions and outcome measures of individual trials are provided in 'Characteristics of included studies'.

\section{Setting}

The publication dates of the main reports of these trials span 13 years; Raskin 1993 being the earliest. Aside from Hutchinson 1995, which had six centres, the studies were single centre trials, 
mainly conducted in teaching hospitals. They each took place in one of six countries (Australia (1), Germany (1), Italy (1), Sweden (1), UK (2), USA (3)).

\section{Participants}

The nine included trials involved a total of 510 participants. One trial (Raskin 1993) provided no information on the gender composition of their study population. For the rest, the percentage of females ranged from $54 \%$ (Sommerkamp 1994) to $100 \%$ (Moroni 2001). The mean ages of the trial populations ranged from 36 years (Sommerkamp 1994) to 74.5 years (Moroni 2001). It is clear that the vast majority of participants in the included trials were skeletally mature: this was explicit in Sommerkamp 1994. Two trials restricted the trial population to more mature adults: Atroshi 2006 (women 50 years or over; men 60 years or over) and Moroni 2001 (aged 65 years or over). The youngest (14 years) and oldest (93 years) participants both belonged to Hutchinson 1995. All participants of Werber 2003 were of working age or retired.

\section{Fractures}

All participants of McQueen 1996 and McQueen 1998 and some of Sommerkamp 1994 had fractures that had redisplaced by two weeks, whereas the other trials involved primary treatment of people with acute fractures. Some fractures in Sommerkamp 1994 were open fractures but it is likely that most of the fractures in the other trials were closed; this was explicit in Hutchinson 1995, Moroni 2001, Raskin 1993 and Werber 2003. The majority of fractures were dorsally displaced; this was mandatory in four trials (Atroshi 2006; McQueen 1996; McQueen 1998; Werber 2003).
Seven trials included both extra-articular and intra-articular fractures, the exceptions being Moroni 2001 (extra-articular fractures only) and Raskin 1993 (intra-articular fractures only). The trial inclusion criteria of Krishnan 2003 stipulated intra-articular fractures, but in fact three of the 60 participants had extra-articular fractures. There were two Barton fractures in the broad spectrum of 90 fractures included in Hutchinson 1995. In contrast, the study population of Raskin 1993 was much narrower and all 60 participants had a die punch fracture (this is an impacted displaced fracture of the lunate facet of the distal radial radiocarpal joint surface). Seven trials classified their fractures according to the AO system (Muller 1991), and the other two trials (Hutchinson 1995; Sommerkamp 1994) used the Frykman system (Frykman 1967). Raskin 1993 also applied the classification system devised by the second author of this trial report (Melone 1993). Four trials (Krishnan 2003; Moroni 2001; Raskin 1993; Werber 2003) provided no criteria of the extent of the displacement required for trial entry. Both Atroshi 2006 and McQueen 1998 indicated the need for sufficiently sized dorsal fragment(s) for insertion of the distal pins of the non-bridging fixators used in these two trials.

\section{Comparisons}

The nine included trials have been grouped according to the main comparison addressed by each trial. A concise summary of the trial participants, fracture types, timing and details of the interventions is given in Table 5. Some indications of major differences in the trials grouped under the same comparison are highlighted below.

Table 5. Key characteristics of participants, fractures and interventions

\begin{tabular}{|c|c|c|c|c|c|}
\hline Study ID & $\begin{array}{l}\text { Participants } \\
\text { gender, age })\end{array}$ & $\begin{array}{l}\text { Fracture type and } \\
\text { classification }\end{array}$ & $\begin{array}{l}\text { Tim- } \\
\text { ing/ common inter- } \\
\text { vention/duration }\end{array}$ & Intervention & Control \\
\hline Atroshi 2006 & $\begin{array}{l}38 ; \quad 82 \% \text { female; } \\
\text { mean age } 71 \text { years. }\end{array}$ & $\begin{array}{l}\text { Acute dorsally dis- } \\
\text { placed (> } 20 \text { degrees } \\
\text { dorsal angulation or } \\
5+\mathrm{mm} \text { radial short- } \\
\text { ening). At least } 2 \\
\text { large articular frag- } \\
\text { ments if intra-artic- } \\
\text { ular. AO types A2, A } \\
3 \text { and C2, C3 (ex- } \\
\text { tra-articular and in- } \\
\text { tra-articular). }\end{array}$ & $\begin{array}{l}\text { Within } 4 \text { days from } \\
\text { injury. Closed re- } \\
\text { duction. } \\
\text { Open incisions for } \\
\text { pin insertion. Exter- } \\
\text { nal fixation for } 6 \\
\text { weeks. }\end{array}$ & $\begin{array}{l}\text { Non-bridged } \\
\text { fixation using /hoff- } \\
\text { man II compact ex- } \\
\text { ternal fixator. Two } \\
\text { pins in radial shaft } \\
\text { and } 2 \text { in distal frac- } \\
\text { ture fragment. In- } \\
\text { structions for early } \\
\text { wrist exercises. }\end{array}$ & $\begin{array}{l}\text { Bridged } \\
\text { (across wrist joint) } \\
\text { fixation using Hoff- } \\
\text { man external fixa- } \\
\text { tor. Two pins in } \\
\text { radial shaft and } 2 \\
\text { in 2nd metacarpal. } \\
\text { Fixator locked. }\end{array}$ \\
\hline Hutchinson 1995 & $\begin{array}{l}89 ; \quad 76 \% \text { female; } \\
\text { mean age } 65 \text { years. }\end{array}$ & $\begin{array}{l}\text { Various fractures in- } \\
\text { cluding Colles' (>20 } \\
\text { degrees dorsal angu- } \\
\text { lation) }\end{array}$ & $\begin{array}{l}\text { Timing not stated. } \\
\text { Closed reduction } \\
\text { and generally percu- }\end{array}$ & $\begin{array}{l}\text { AO external fixa- } \\
\text { tor; } 2 \text { pins in radial } \\
\text { shaft and } 2 \text { in } 2 \text { nd }\end{array}$ & $\begin{array}{l}\text { Two pins in ra- } \\
\text { dial shaft and } 1 \text { in } \\
\text { metacarpals in plane }\end{array}$ \\
\hline
\end{tabular}


Table 5. Key characteristics of participants, fractures and interventions (Continued)

\begin{tabular}{|c|c|c|c|c|c|}
\hline & & $\begin{array}{l}\text {. Frykman (mainly } \\
\mathrm{V} \text { to VIII), proba- } \\
\text { bly extra-articular as } \\
\text { well as intra-articu- } \\
\text { lar. }\end{array}$ & $\begin{array}{l}\text { taneous insertion of } \\
\text { pins. } \\
\text { Trans-articular fixa- } \\
\text { tion for } 3 \text { to } 12 \\
\text { weeks (mean } 7.6 \\
\text { weeks). }\end{array}$ & metacarpal. & $\begin{array}{l}\text { of palm. Pins incor- } \\
\text { porated into plaster. }\end{array}$ \\
\hline Krishnan 2003 & $\begin{array}{l}60 ; \quad 68 \% \text { female; } \\
\text { mean age } 56 \text { years. }\end{array}$ & $\begin{array}{l}\text { Mainly intra-articu- } \\
\text { lar including com- } \\
\text { plex and commin- } \\
\text { uted. } \\
\text { types A3.2, B2.1, } \\
\text { C1, C2, C3 (extra- } \\
\text { articular and intra- } \\
\text { articular). }\end{array}$ & $\begin{array}{l}\text { Timing not stated. } \\
\text { Closed reduction. } \\
\text { Open incisions for } \\
\text { pin insertion. Exter- } \\
\text { nal fixation for } 6 \\
\text { weeks. }\end{array}$ & $\begin{array}{l}\text { Non-bridged } \\
\text { fixation using Delta } \\
\text { frame external fixa- } \\
\text { tor. One pin in ra- } \\
\text { dial shaft and } 4 \text { in } \\
\text { distal fracture frag- } \\
\text { ments in } 2 \text { horizon- } \\
\text { tal planes. Free wrist } \\
\text { movement. }\end{array}$ & $\begin{array}{l}\text { Bridged } \\
\text { (across wrist joint) } \\
\text { fixation with Hoff- } \\
\text { man II Compact } \\
\text { frame. Two pins in } \\
\text { radial shaft and } 2 \text { in } \\
\text { 2nd metacarpal. }\end{array}$ \\
\hline McQueen 1996 & $\begin{array}{l}60 \text { of } 120 \text { in com- } \\
\text { parison; } 88 \% \text { fe- } \\
\text { male; mean age } 64 \\
\text { years. }\end{array}$ & $\begin{array}{l}\text { Redis- } \\
\text { placed (>10 degrees } \\
\text { dorsal angulation / } \\
>3 \mathrm{~mm} \text { radial short- } \\
\text { ening). AO types A } \\
\text { and C (extra-articu- } \\
\text { lar and intra-articu- } \\
\text { lar). }\end{array}$ & $\begin{array}{l}\text { Within } 2 \text { weeks } \\
\text { from injury. Closed } \\
\text { reduction. } \\
\text { Open } \\
\text { incisions for pin in- } \\
\text { sertion. Trans-artic- } \\
\text { ular fixation. Pennig } \\
\text { external fixator for } 6 \\
\text { weeks. }\end{array}$ & $\begin{array}{l}\text { Ball joint of fixator } \\
\text { released for limited } \\
\text { wrist motion at } 3 \\
\text { weeks. }\end{array}$ & $\begin{array}{l}\text { Ball joint remained } \\
\text { locked. }\end{array}$ \\
\hline McQueen 1998 & $\begin{array}{l}60 ; 92 \% \text { female; } \\
\text { mean age } 61 \text { years. }\end{array}$ & 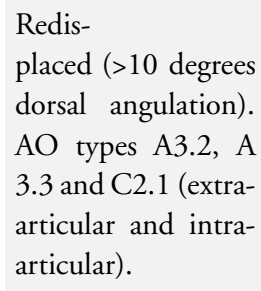 & $\begin{array}{l}\text { Within } 2 \text { weeks } \\
\text { from injury. Closed } \\
\text { reduction. } \\
\text { Open incisions for } \\
\text { pin insertion. Pen- } \\
\text { nig external fixator } \\
\text { for } 6 \text { weeks. }\end{array}$ & $\begin{array}{l}\text { Non-bridged } \\
\text { fixation. Two pins } \\
\text { in radial shaft and } \\
2 \text { in distal fracture } \\
\text { fragment. Free wrist } \\
\text { movement. }\end{array}$ & $\begin{array}{l}\text { Bridged } \\
\text { (across wrist joint) } \\
\text { fixation. Two pins in } \\
\text { radial shaft and } 2 \\
\text { in 2nd metacarpal. } \\
\text { Ball joint locked. }\end{array}$ \\
\hline Moroni 2001 & $\begin{array}{l}20 \text {; all females with } \\
\text { osteoporosis; mean } \\
\text { age } 74.5 \text { years. }\end{array}$ & $\begin{array}{l}\text { Extra-articular wrist } \\
\text { fracture. AO types } \\
\text { A2 and A3. }\end{array}$ & $\begin{array}{l}\text { Timing and reduc- } \\
\text { tion not } \\
\text { stated. Trans-articu- } \\
\text { lar fixation: } 2 \text { pins } \\
\text { in distal radius and } \\
2 \text { in } 2 \text { nd metacarpal. } \\
\text { Small incisions for } \\
\text { pin insertion. Pen- } \\
\text { nig II external fix- } \\
\text { ator applied for } 6 \\
\text { weeks. }\end{array}$ & $\begin{array}{l}\text { Hydroxyapatite } \\
\text { coated tapered pins. }\end{array}$ & $\begin{array}{l}\text { Standard uncoated } \\
\text { tapered pins. }\end{array}$ \\
\hline
\end{tabular}

Raskin 1993 60; \% female un- Unstable intra- Within 2 weeks of Uniplaner Percutaneous inserknown; mean age 45 articular distal ra- injury (1-14 days). external fixator; 2 tion of one Steinyears.

dial fractures. Mel- Closed reduction 
Table 5. Key characteristics of participants, fractures and interventions (Continued)

\begin{tabular}{|c|c|c|c|c|c|}
\hline & & $\begin{array}{l}\text { one IIA and IIB; AO } \\
\text { type C. }\end{array}$ & $\begin{array}{l}\text { prior to surgery in } \\
14 \text { patients. Manip- } \\
\text { ulation under trac- } \\
\text { tion for both oper- } \\
\text { ations and probably } \\
\text { further reduction by } \\
\text { sup- } \\
\text { plementary percuta- } \\
\text { neous Kirschner } \\
\text { wire(s) used to fix } \\
\text { fracture in most pa- } \\
\text { tients. Open reduc- } \\
\text { tion in } 5 \text { patients. } \\
\text { Trans-articular fixa- } \\
\text { tion for } 8 \text { weeks. }\end{array}$ & $\begin{array}{l}\text { threaded pins in ra- } \\
\text { dial shaft and } 2 \text { in } \\
\text { 2nd metacarpal, in- } \\
\text { serted using limited } \\
\text { open techniques. }\end{array}$ & $\begin{array}{l}\text { mann pin in ra- } \\
\text { dial shaft and } 1 \\
\text { through 2nd and } \\
\text { 3rd metacarpals. } \\
\text { Pins incorporated } \\
\text { into plaster. }\end{array}$ \\
\hline Sommerkamp 1994 & $\begin{array}{l}73 \text {; of } 48: 54 \% \text { fe- } \\
\text { male; mean age } 36 \\
\text { years. }\end{array}$ & $\begin{array}{l}\text { Displaced }(>20 \text { de- } \\
\text { grees dorsal angu- } \\
\text { lation / >10 mm } \\
\text { radial shortening)or } \\
\text { unstable intra-artic- } \\
\text { ular and commin- } \\
\text { uted fractures, or } \\
\text { post-reduction (per- } \\
\text { sistent radial short- } \\
\text { ening / dor- } \\
\text { sal angulation)or re- } \\
\text { displaced (loss volar } \\
\text { tilt }>5 \text { degrees }>5 \\
\text { mm radial shorten- } \\
\text { ing). Frykman I to } \\
\text { VIII (extra-articular } \\
\text { and intra-articular). }\end{array}$ & $\begin{array}{l}\text { After primary closed } \\
\text { reduction or within } \\
2 \text { weeks from injury. } \\
\text { Closed reduction. } \\
\text { Trans-articular fixa- } \\
\text { tion for } 6 \text { to } 11 \\
\text { weeks. }\end{array}$ & $\begin{array}{l}\text { Dynamic Clyburn } \\
\text { external } \\
\text { fixator. Limited mo- } \\
\text { bilisation around } 2 \\
\text { weeks, full mobilisa- } \\
\text { tion } \\
\text { around } 4 \text { weeks. }\end{array}$ & $\begin{array}{l}\text { Static AO/ASIF ex- } \\
\text { ternal fixator. }\end{array}$ \\
\hline Werber 1999 & $\begin{array}{l}50 ; \quad 70 \% \text { female; } \\
\text { mean age } 58.5 \text { years. }\end{array}$ & $\begin{array}{l}\text { Un- } \\
\text { stable dorsally angu- } \\
\text { lated fracture. AO } \\
\text { types A2.2, A3.1, } \\
\text { A3.2, and C2.1, } \\
\text { C2.2, C2.3) (extra- } \\
\text { articular and intra- } \\
\text { articular). }\end{array}$ & $\begin{array}{l}\text { Fixa- } \\
\text { tion within } 10 \text { days } \\
\text { of injury. Closed } \\
\text { reduction; intra-ar- } \\
\text { ticular fractures re- } \\
\text { duced using percu- } \\
\text { taneous wire. } \\
\text { Standard } 4 \text { pin small } \\
\text { AO (ASIF) fixator } \\
\text { for approximately } 9 \\
\text { weeks. }\end{array}$ & $\begin{array}{l}\text { Additional pin in- } \\
\text { serted per- } \\
\text { cutaneously to fix } \\
\text { the "floating" distal } \\
\text { fracture fragment. } \\
\text { Pin attached to fixa- } \\
\text { tor frame. Removed } \\
\text { after } 7 \text { weeks. }\end{array}$ & $\begin{array}{l}\text { Standard fix- } \\
\text { ator; distal fragment } \\
\text { not fixed. }\end{array}$ \\
\hline
\end{tabular}




\section{Primary methods}

External fixator versus pins and plaster external fixation

Two trials (Hutchinson 1995; Raskin 1993), involving 89 and 60 participants respectively, compared a bridging external fixator with pins and plaster external fixation. Among the known differences between the two trials were the older and more varied population of Hutchinson 1995 (mean age 65 years compared with 45 years in Raskin 1993) and the different pinning configurations in the pins and plaster group (see Table 5).

\section{Non-bridging versus bridging external fixation}

Three trials (Atroshi 2006; Krishnan 2003; McQueen 1998), involving 38, 60 and 60 participants respectively, compared a nonbridging with a bridging external fixator. In contrast to Atroshi 2006 and Krishnan 2003, McQueen 1998 only included redisplaced fractures. In the non-bridging groups of Atroshi 2006 and McQueen 1998, the two pins inserted into the distal fracture fragment(s) acted primarily as 'anchors'. In Krishnan 2003, which used the 'Delta frame' external fixator, the four pins inserted into the distal fracture fragments either transfixed the fracture fragments or, in severely comminuted fractures, functioned as subarticular supports.

Augmented external fixation involving supplementary percutaneous pinning versus external fixation alone

One trial (Werber 2003) involving 50 participants examined the use of an additional pin, inserted percutaneously, to fix the 'floating' distal fragment. The pin was then attached to fixator frame.

\section{Different subsidiary components of surgical technique}

There were no trials in this category.

\section{Different types of fixation devices}

Hydroxyapatite coated pins versus standard uncoated pins

One trial (Moroni 2001) involving 50 female participants with osteoporosis compared external fixation using hydroxyapatite coated tapered pins versus standard uncoated tapered pins.

\section{Different types or duration of post-operative immobilisation}

Dynamic versus static external fixation

Two trials (McQueen 1996; Sommerkamp 1994), involving 60 and 73 participants respectively, compared dynamic versus static external fixation. All fractures were redisplaced in McQueen 1996, whereas only some (proportion unknown) were in Sommerkamp 1994. The same fixator was used in both groups in McQueen 1996 but different fixators were used in Sommerkamp 1994. The timing and extent of dynamism of the fixator also varied between the two trials (see Table 5).

\section{Excluded studies}

Eight studies were excluded for reasons stated in 'Characteristics of excluded studies'. Three studies were found not to be randomised trials and one will be a biomechanical study. There was insufficient information on three other trials (Rawes 1995; Stoffelen 1999; Stokes 1998) published only as conference abstracts. Both Rawes 1995 and Stokes 1998 appeared as included trials in Handoll 2003a. The complex study design of Hutchinson 2000 prevented the direct conclusions on clinical outcome.

\section{Ongoing studies}

No ongoing studies were identified.

\section{Studies awaiting assessment}

Details of the four trials pending assessment are given below.

Basdekis 2005: published abstracts of trial comparing fluoroscopic versus arthroscopic reduction of intra-articular fractures in 40 people given external fixation provide insufficient information for inclusion. No response obtained yet from authors.

Hove 2005: published abstract of trial, which compared a dynamic external fixator designed by the authors versus a traditional static external fixator in 70 people with distal radial fractures, provides insufficient information for inclusion. No response obtained yet from authors.

McQueen 2006: trial registered as ongoing in the National Trials Register (UK) has yet to begin (March 2007). If the trial, which includes a comparison of external fixation with percutaneous pinning versus non-bridging external fixation, takes place it is likely to be a single-centre trial.

Tornetta 2005: two published abstracts of a trial examining the reuse of external fixation components in a mixed fracture population provide insufficient information for inclusion. Trial author has indicated that a full report has been submitted for publication. Separate data for distal radial fractures (48 recruited) will be required before inclusion.

\section{Risk of bias in included studies}

The quality of trial methodology, judged using the 11 quality criteria listed in Table 3, is somewhat disappointing. Associated with this is a high potential for the key systematic biases (selection, performance, assessment and attrition) leading to questions about internal validity, and issues of clinical relevance and applicability or external validity. These will be considered further in the 'Discussion'. The results, together with some notes on specific aspects, of the quality assessment for the individual trials are shown in Table 6. Information specific to the first three items of the quality assessment is given in the methods sections of 'Characteristics of included studies'. A summary of the results for individual items of quality assessment is given below. 


\begin{abstract}
Allocation concealment (item 1)
Only one trial (Atroshi 2006), which used sequentially-opened numbered sealed and opaque envelopes, was considered to have satisfied the criteria for secure allocation concealment. It was unclear whether allocation was concealed prior to randomisation in six trials. Three of these used closed envelopes (Krishnan 2003; McQueen 1996; McQueen 1998), one used a computer generated list (Moroni 2001), and two trials provided no direct information (Raskin 1993; Werber 2003). The two remaining trials (Hutchinson 1995; Sommerkamp 1994) used quasi-randomised methods based on record or chart numbers.
\end{abstract}

Table 6. Quality assessment results for individual trials (see Table 04 for scheme)

\begin{tabular}{|c|c|c|c|c|}
\hline Study ID & Items and grades & Items and grades & Items and grades & Notes \\
\hline Study ID & $\begin{array}{l}\text { Item 1: Allocation con- } \\
\text { cealment Item 2: In- } \\
\text { tention-to-treat analysis } \\
\text { Item 3: Outcome assessor } \\
\text { blinding Item 4: Compa- } \\
\text { rable baseline characteris- } \\
\text { tics }\end{array}$ & $\begin{array}{l}\text { Item 5: Participant blind- } \\
\text { ing Item 6: Treatment } \\
\text { provider blinding Item } \\
\text { 7: Identical care pro- } \\
\text { grammes Item 8: Clearly } \\
\text { defined inclusion criteria }\end{array}$ & $\begin{array}{l}\text { Item 9: Well defined out- } \\
\text { come measures Item 10: } \\
\text { Optimal outcome assess- } \\
\text { ment Item 11: Optimal } \\
\text { timing of follow up (> } 1 \\
\text { year) In brackets: date of } \\
\text { last follow up; \% lost to } \\
\text { last follow up }\end{array}$ & $\begin{array}{l}\text { Comments and explana- } \\
\text { tions for specific items }\end{array}$ \\
\hline Atroshi 2006 & $\mathrm{Y}, \mathrm{Y}, ?, \mathrm{Y}$ & $\mathrm{N}, \mathrm{N}, \mathrm{Y}, \mathrm{Y}$ & $\begin{array}{l}\mathrm{Y}, \mathrm{Y}, \text { ? (1 year; } 5 \% \text { at } 1 \\
\text { year) }\end{array}$ & $\begin{array}{l}\text { Item 3: blinding for phys- } \\
\text { ical examination (grip } \\
\text { strength, range of mo- } \\
\text { tion). }\end{array}$ \\
\hline Hutchinson 1995 & $\mathrm{~N}, ?, \mathrm{~N}$, ? & $\mathrm{N}, \mathrm{N}, ?, \mathrm{Y}$ & $\begin{array}{l}\mathrm{Y}, \text { ?, } \mathrm{Y} \text { ( } 2 \text { years; } 8 \% \text { at } 1 \\
\text { year) }\end{array}$ & $\begin{array}{l}\text { Item } 11 \text { : note that only } \\
52 / 60 \text { were followed up at } \\
2 \text { years; } 13 \% \text { lost to last } \\
\text { follow up. Rest only fol- } \\
\text { lowed up } 1 \text { year. }\end{array}$ \\
\hline Krishnan 2003 & ?, ?, N, ? & $\mathrm{N}, \mathrm{N}, ?, \mathrm{Y}$ & Y, ?, ? (1 year; ?\%) & $\begin{array}{l}\text { Item 2: no report of drop- } \\
\text { outs. } \\
\text { Item 4: small imbalances } \\
\text { in numbers of males, age } \\
\text { and hand dominance. }\end{array}$ \\
\hline McQueen 1996 & ?, Y, N, Y & $\mathrm{N}, \mathrm{N}$, ?, Y & Y, ?, ? (1 year; $10 \%)$ & \\
\hline McQueen 1998 & $\mathrm{Y}$, ?, N, Y & $\mathrm{N}, \mathrm{N}, \mathrm{Y}, \mathrm{Y}$ & Y, ?, ? (1 year; 7\%) & $\begin{array}{l}\text { Item 2: some discrepan- } \\
\text { cies in full trial report and } \\
\text { between full report and } \\
\text { one abstract. }\end{array}$ \\
\hline
\end{tabular}


Table 6. Quality assessment results for individual trials (see Table 04 for scheme) (Continued)

\begin{tabular}{|c|c|c|c|c|}
\hline Moroni 2001 & ?, ?, N, Y & $\mathrm{N}, \mathrm{N}$, ?, Y & Y, ?, N (6 weeks; 5\%?) & $\begin{array}{l}\text { Item 2: loss to follow up } \\
\text { not reported but missing } \\
\text { data points on graph for } 1 \\
\text { person. }\end{array}$ \\
\hline Raskin 1993 & ?, ?, N, N & $\mathrm{N}, \mathrm{N}, ?, ?$ & $\begin{array}{l}\text { ?, N, Y (12 to } 60 \text { months; } \\
0 \%)\end{array}$ & $\begin{array}{l}\text { Item 4: no information } \\
\text { on gender, difference in } \\
\text { mean ages, } 5 \text { more seri- } \\
\text { ous fractures in the exter- } \\
\text { nal fixator group. } \\
\text { Item 10: variable length } \\
\text { of follow up. }\end{array}$ \\
\hline Sommerkamp 1994 & $\mathrm{~N}, \mathrm{~N}, \mathrm{~N}, \mathrm{~N}$ & $\mathrm{~N}, \mathrm{~N}, ?, \mathrm{Y}$ & $\begin{array}{l}\text { Y, ?, Y (12 months after } \\
\text { fixator removal; 34\%) }\end{array}$ & $\begin{array}{l}\text { Item 2: exclusions for } \\
\text { non-compliance with re- } \\
\text { habilitation regimen. } \\
\text { Item 4: data not provided } \\
\text { for whole group. }\end{array}$ \\
\hline Werber 2003 & ?, ?, N, Y & $\mathrm{N}, \mathrm{N}, \mathrm{Y}$, ? & $\mathrm{Y}$, ?, ? (6 months, $0 \%)$ & $\begin{array}{l}\text { Item 2: some discrepan- } \\
\text { cies between full report } \\
\text { and the two abstract re- } \\
\text { ports. } \\
\text { Item 3: independent as- } \\
\text { sessment of radiographs. }\end{array}$ \\
\hline
\end{tabular}

Intention-to-treat analysis (item 2)

Clear statements of participant flow with evidence of intentionto-treat analysis, together with consistent reporting, were available for Atroshi 2006 and McQueen 1996. Sommerkamp 1994 had an ' $\mathrm{N}$ ' rating because of the exclusion from the analyses of trial participants for non-compliance with rehabilitation.

\section{Blinding of outcome assessors (item 3)}

Atroshi 2006 reported blinded physical assessment and, while not rated, three trials (Krishnan 2003; Sommerkamp 1994; Werber 2003) referred to independent assessors of radiographs. Total blinding of outcome assessment is impractical for trials testing surgical interventions but, as shown by Atroshi 2006, it is possible for some outcomes and more so at longer-term follow up.

Comparability of baseline characteristics (item 4)
Five trials (Atroshi 2006; McQueen 1996; McQueen 1998; Moroni 2001; Werber 2003) provided sufficient information indicating the similarity in the baseline characteristics of gender, age and type of fracture. Potentially important imbalances in age and fracture severity between the two treatment groups of Raskin 1993, and a lack of baseline characteristics for Sommerkamp 1994 were reasons for an 'N' rating for these two trials.

Blinding of patients and treatment providers (items 5 and 6)

These are unlikely in these studies and none was claimed.

Care programme comparability (item 7)

We found it difficult to confirm comparability of care programmes, including surgical experience, other than the trial interventions. Nonetheless, we judged it highly likely in three trials (Atroshi 2006; McQueen 1998; Werber 2003).

Description of inclusion criteria (item 8) 
Aside from Raskin 1993 and Werber 2003, the included trials provided sufficient trial inclusion and exclusion criteria to define their study populations.

\section{Definition and quality of outcome measurement (items 9 and} 10)

Outcome measurement was sufficiently well described in all of the included trials except Raskin 1993. Raskin 1993 was also considered to have inadequate outcome measurement, which included follow up of variable duration. Only Atroshi 2006 was rated as having 'optimal' quality outcome measurement, which included use of validated patient assessed quality of life instruments and active follow up. Of note is the grading or scoring of overall functional outcome according to non-validated scoring systems in several trials. These systems, which often included anatomical and clinical outcomes, included modifications of other scoring systems such as that of Gartland and Werley (Gartland 1951). The variety of schemes used and other outcome measures reported by the trials is evident from inspection of 'Characteristics of included studies'.

\section{Length of follow up (item 11)}

Follow up ranged from six weeks (Moroni 2001) to a maximum of five years (Raskin 1993). Follow up of variable duration, particularly at times where participants are at different stages of recovery, may be a potential cause of bias such as in Raskin 1993 (12 to 60 months).

\section{Loss to follow up (not rated)}

Loss to follow up was substantial in Sommerkamp 1994, where a third of participants were missing from the final analyses. While the loss to follow up at one year was modest (8\%) in Hutchinson 1995 , only $58 \%$ of the original study population were followed up at two years. For some of the trials appearing to have no losses, it may be the case that these were not reported.

\section{Effects of interventions}

External fixator versus pins and plaster external fixation Two trials (Hutchinson 1995; Raskin 1993), involving 89 and 60 participants respectively, compared a bridging external fixator with pins and plaster external fixation. The characteristics of the external fixators and the pinning configurations in the pins and plaster group differed between the two trials (see Table 5). There was no pooling of the two outcomes (both complications) reported by both trials.

Both trials found no statistically significant differences in functional outcome. All participants of Raskin 1993 returned to their former activities of daily living. Assessed using a functional grading scheme that included radiographical results, similar numbers of participants in the two groups of Raskin 1993 had only 'fair' functional grades (see Analysis 01.01: $5 / 30$ versus 4/30; relative risk (RR) $1.25,95 \%$ confidence interval (CI) 0.37 to 4.21 ). While people in the external fixator group of Hutchinson 1995 tended to experience less pain or discomfort at one year (see Analysis 01.02:
6/42 versus $12 / 40$; RR $0.48,95 \%$ CI 0.20 to 1.15 ), equal numbers of people in each group experienced functional difficulty (3 versus 3) and weakness (26 versus 26). Hutchinson 1995 reported that there were no statistically significant differences between the two groups in the findings for mass grip strength (see Analysis 01.03), range of motion for wrist and fingers, or finger stiffness (tightness). Similarly, Raskin 1993 reported that there were no statistically significant differences in the various measures of functional impairment: grip strength relative to normal side ( $80 \%$ versus $85 \%$ ); flexion/extension $\left(122^{\circ}\right.$ versus $\left.126^{\circ}\right)$; and pronation/supination $\left(156^{\circ}\right.$ versus $\left.150^{\circ}\right)$.

Complications, graded as minor (resolved, short term) and major (serious consequences, persistent) in Hutchinson 1995, for both trials are presented in Analysis 01.04. The overall numbers of participants of Hutchinson 1995 with "major" complications were similar in both groups (12/44 versus 10/46). However, eight of the 10 "major" complications were loss of reduction in the pins and plaster, whereas the four pin track infections with serious sequelae and four cases of persistent radial neuritis were found in the external fixator group. Significantly more people in the external fixator group of Hutchinson 1995 suffered pin track complications (11/44 versus $2 / 46$; RR 5.75 , $95 \%$ CI 1.35 to 24.48 ) and radial neuritis (8/44 versus $1 / 46$; RR $8.36,95 \%$ CI 1.09 to 64.15 ). There were similar numbers of participants in the two groups with carpal tunnel syndrome, which Hutchinson 1995 considered to be a complication of the injury rather than treatment. Two other major complications were a new radial fracture after removal of the pins and plaster in the pins in plaster group, and a tendon adhesion with a pin in the external fixator group, requiring tenolysis. There were few complications in Raskin 1993 and all resolved. The eight cases of median nerve compression in Raskin 1993 were resolved by closed reduction before external fixation. There was no significant difference in the numbers of participants who were dissatisfied with their outcome in Hutchinson 1995 (see Analysis 01.05: 7/42 versus 9/40; RR 0.74, 95\% CI 0.30 to 1.80 ).

Fewer participants, but not statistically significantly so, of the external fixator group in Hutchinson 1995 had a major loss in reduction (see Analysis 01.04 Loss of reduction: 2/44 versus 8/46; RR $0.26,95 \%$ CI 0.06 to 1.16 ). All resulted in subjectively assessed wrist deformity. Pin loosening, without infection, and pin fracture caused the loss of reduction in four participants of the pins in plaster group; the other six cases were stated as having resulted from incomplete reduction before fixation. Hutchinson 1995 reported no significant differences between the two groups in volar tilt, radial angle or radial length at one-year follow up. One loss of reduction requiring remanipulation occurred in the external fixator group in Raskin 1993. Just three participants of Raskin 1993 had an unsatisfactory anatomical grading (see Analysis 01.06) and no statistically significant difference was reported in the radiographic comparison of the two groups. Out of 52 participants followed up at two years in Hutchinson 1995, 20 had signs of early degenerative arthritis of which four had significant 
joint disease; separate data for the two groups were not available. Hutchinson 1995 estimated the initial material cost in the US for an external fixator was around 20 times higher than pins and plaster (\$775 versus \$38).

\section{Non-bridging versus bridging external fixation}

Three trials (Atroshi 2006; Krishnan 2003; McQueen 1998), involving 38, 60 and 60 participants respectively, compared nonbridging with bridging external fixation. As described above and summarised in Table 5, there was marked variation in the trial populations and interventions of these three trials. Data for the few outcome measures in common were not pooled.

Atroshi 2006 found no significant differences between the two groups at any follow-up time in the DASH (Disabilities of the Arm, Shoulder and Hand) scores (see Analysis 02.01: mean difference (MD) 4.00 , 95\% CI -2.66 to 10.66 ) and SF-12 physical domain scores (see Analysis 02.02: MD 1.00, 95\% CI -4.64 to 6.64). By 12 weeks, both groups in Krishnan 2003 achieved almost top scores for a 17-task activities of daily living scoring tool (no data reported). While grip strength results in Atroshi 2006 tended to favour the non-bridged group at all three followup times, the differences between the two groups did not reach statistical significance (see Analysis 02.03: MD $5.00 \mathrm{~kg}$, 95\% 2.05 to $12.05 \mathrm{~kg}$ ). There was no significant difference between the two groups of Krishnan 2003 (\% of uninjured side, medians: $45 \%$ versus $43 \%$ ). The extreme range data ( $0 \%$ to $180 \%$ ) for grip strength in Krishnan 2003 was not explained; in particular, how at least two participants had no grip strength. However, the nonbridging fixator group in McQueen 1998 had statistically significantly better grip strength (see Analysis 02.04). None of trials found differences between the two groups in numbers of participants with residual pain (see Analysis 02.05) or in pain scores: Atroshi 2006 (see Analysis 02.06); Krishnan 2003 (medians at 26 weeks: 0 versus 0); McQueen 1998 (VAS: 1.2 versus 1.3 , (10 is worst pain)). Atroshi 2006 found very similar values for range of motion measures in the two groups (see Analysis 02.07). Flexion was reported as statistically significantly lower in the non-bridging group of Krishnan 2003 (medians: $50^{\circ}$ versus $60^{\circ}$ ) but significantly higher in McQueen 1998 (see Analysis 02.08). Of note is the extreme upper range values of $100^{\circ}$ for flexion in Krishnan 2003.

None of the differences between the two groups of any of the three trials in the numbers of people with individual complications were statistically significant (see Analysis 02.09). All pin-track infections in Atroshi 2006 resolved with antibiotics. The two iatrogenic fractures in the bridging group of this trial were respectively: a) a fracture of the second metacarpal that occurred after fixator removal; and b) an inconsequential proximal pin-site fracture detected after a subsequent fall. There were discrepancies in the reporting of the complications between text and table in Krishnan 2003; and some complications were not defined. One person with pin track infection of each group required hospital admission. The person in the bridging group, who required surgery and early removal of their fixator, also incurred a metacarpal fracture (during manipulation under anaesthesia for finger stiffness) and developed reflex sympathetic dystrophy (RSD). The other people requiring further "surgery" in Krishnan 2003 were two non-bridging group participants (one had open reduction and internal fixation; the other had manipulations for finger stiffness) and one bridging group participant (distal ulna resection for persistent distal radio-ulnar joint pain). There was no mention of the treatment received by the three people of the non-bridging group who had an extensor pollicis longus rupture. There was a discrepancy in the numbers with serious complications (5 compared with 4 ) reported in the trial report of McQueen 1998 and an earlier abstract (published 1997). However, the numbers of serious complications in the two groups were probably similar or the same. McQueen 1998 stated that neither of the tendon ruptures was related to the pins and that there were no cases of pin loosening. Two participants, both in the non-bridging fixation group, were dissatisfied with their outcome in Atroshi 2006 (see Analysis 02.10).

Fracture redisplacement resulting in a further operation occurred in one person of the bridging group in Atroshi 2006. Two people in each group had fixation failure in Krishnan 2003 (see Analysis 02.09). All fractures were reported as healed in Atroshi 2006 who reported non-bridging fixation was better at maintaining radial length, as shown by the statistically significantly lower ulnar variance for this group (see Analysis 02.12). Atroshi 2006 found no significant differences in volar tilt or radial inclination, and reported that no fracture had an articular step-off exceeding one millimetre. Krishnan 2003 reported no significant differences between the two groups in radiological measurements: palmar tilt (medians: $6.5^{\circ}$ versus $7^{\circ}$ ), radial inclination (medians: $18.5^{\circ}$ versus $22^{\circ}$ ), radial length (medians: 7.5 versus $8 \mathrm{~mm}$ ), or radial step (medians: 0 versus $0 \mathrm{~mm}$ ). In contrast, McQueen 1998 reported that the better reduction achieved in the non-bridging fixator group persisted at one year and a superior anatomical result was obtained for this group (see Analyses 02.11, 02.12 and 02.13). Notably, there were no cases of malunion in the non-bridging group compared with 14 in the bridging group (see Analysis 02.13: RR 0.03, 95\% CI 0.00 to 0.55$)$.

In Atroshi 2006, surgery took 10 minutes longer in the non-bridging group (see Analysis 02.14).

\section{Augmented external fixation involving supplementary percu-} taneous pinning versus external fixation alone

One trial (Werber 2003) evaluated the effect of pinning the distal fragment in 50 people with unstable dorsally-displaced distal radial fractures treated by external fixation. The report of this trial in Handoll 2003a was based on two conference abstracts, which presented radiological findings only. No explanation has been received from the trial authors for the discrepancies between the abstract and full reports of the trial in the participant characteristics. In the following, only the data on ulnar plus variance are obtained from an abstract report.

Based on a functional assessment scheme including some consid- 
eration of symptomatic deformity (Lidstrom 1959), significantly more people in the extra-pin group had a 'very good' functional grading at six months; in other words, a lower proportion of people treated with supplementary percutaneous pinning had a 'not very good' grading (see Analysis 03.01: 7/25 versus 19/25; RR 0.37, 95\% CI 0.19 to 0.72 ). Additionally fewer people in the extra pin group had only a fair or poor grading (see Analysis 03.01: 1/25 versus 4/25; RR $0.25,95 \%$ CI 0.03 to 2.08 ). This is reflected in the findings in favour of the extra-pin group for grip strength (see Analysis 03.02) and range of motion (see Analysis 03.03). There were few complications (see Analysis 03.04). Six people in each group had pain and swelling necessitating medication averaging two months each person. There was no statistically significant difference between the two groups in the incidence of pin site problems (just one was an infection). One person (intervention group unknown) had temporary paraesthesias of thumb, index and long fingers that subsided after the removal of a metacarpal pin.

All fractures healed. Anatomical outcome was reported to be statistically significantly superior in the extra-pin group (e.g. volar tilt (normal $=10^{\circ}$ ): $6^{\circ}$ versus $-2^{\circ}$, reported $\mathrm{P}<0.001$ ). Post reduction radial shortening, which occurred in both groups, resulted in significantly fewer participants with an ulnar plus variance in the extra pin group (see Analysis 03.05: 3/25 versus 18/23; RR $0.15,95 \%$ CI 0.05 to 0.45 ). Articular step-off was less than one millimetre for all participants.

Consistent with the additional procedure, the surgery took 10 minutes longer in the supplementary pinning group (see Analysis 03.06).

\section{Hydroxyapatite coated pins versus standard uncoated pins}

No functional or anatomical results were reported by Moroni 2001, which compared hydroxyapatite coated tapered pins versus standard (uncoated) tapered pins in 20 older women with osteoporosis who had extra-articular fractures treated with external fixation. There were two low grade pin track infections, requiring only local treatment, in the standard pin group (see Analysis 04.01). One participant of each group had RSD. All fractures healed and no additional cast or orthosis was required after fixator removal. Moroni 2001 found significantly greater torque (force) was required to remove pins coated with hydroxyapatite (see Analysis 04.02). This was interpreted as reflecting an enhancement of the bone-pin interface, with implications for management of patients with osteoporotic bone. The mean and standard deviation visual analogue scores for pain during pin removal were the same in both groups.

\section{Dynamic versus static external fixation}

Two trials (McQueen 1996; Sommerkamp 1994) evaluated early mobilisation of the wrist during external fixation. All 60 participants of McQueen 1996 and some participants of Sommerkamp 1994 had redisplaced fractures. The key differences in the interventions of the two trials are shown in Table 5. Sommerkamp 1994 presented outcome data for only 48 people (50 fractures) of the 73 people ( 75 fractures) recruited into the trial. Given the potential bias resulting from this large loss to follow up (34\%), we have not conducted sensitivity analyses to examine the small disparity between the units of analysis and randomisation in Sommerkamp 1994. There was no pooling of the few outcomes (all complications) reported by both trials.

McQueen 1996 reported there were no statistically significant differences between the two groups in the ability to perform activities of daily living. Based on a scoring scheme (modified Gartland 1951) that included some anatomical measures and complications, Sommerkamp 1994 found a statistically non-significant tendency to better functional grades in the static fixator group (see Analysis 05.01. e.g. Fair or poor: $6 / 25$ versus $2 / 25$; RR 3.00 , $95 \%$ CI 0.67 to 13.46). However, the large loss to follow up renders this unreliable: Analysis 05.01 also shows a best-case (for dynamic fixation) and then a worst-case analysis for this outcome. The result strongly favours dynamic fixation when it is assumed that all participants lost to follow up or excluded in this group had a good or better result compared with none of those lost or excluded from the static fixation group. Conversely, the result strongly favours static fixation. There were no significant differences between the two groups in grip strength for either McQueen 1996 (see Analysis 05.02) or, as reported, in Sommerkamp 1994 (mean grip strength expressed as percentage of uninjured wrist: $72 \%$ versus $78 \%$ ). McQueen 1996 also found no significant differences between the two groups in range of motion (see Analysis 05.03), whereas in Sommerkamp 1994 the higher values for flexion $\left(52.4^{\circ}\right.$ versus $\left.59.4^{\circ}\right)$ and radial deviation $\left(14.8^{\circ}\right.$ versus $\left.21.3^{\circ}\right)$ in the static fixator group were reported to be statistically significant $(\mathrm{P}<0.05)$.

Complications are presented in Analysis 05.04: null events have been entered when reported. None of the differences between the two groups in any complication was statistically significant in either trial. Of note, however, are the five cases of unstable or broken dynamic fixator in Sommerkamp 1994.

Any slight differences in radiological measurements and measures of wrist deformity between the two intervention groups in McQueen 1996 did not reach statistical significance (see Analyses 05.05, 05.06 and 05.07). Seven in each group had recurrent instability (see Analysis 05.04). In Sommerkamp 1994, the mean loss in radial length at the time of fixator removal (around 10 weeks) was reported to be significantly more in the dynamic fixation group ( $4 \mathrm{~mm}$ versus $1 \mathrm{~mm}$ ). There was no difference at this time for dorsal angulation (means: $8^{\circ}$ versus $6^{\circ}$ ). There were no statistically significant differences between the two groups of Sommerkamp 1994 in the numbers of people with moderate or severe radiological deformity (Lidstrom 1959) or with residual articular incongruity (> $2 \mathrm{~mm}$ ) at fixator removal (see Analysis 05.07). Radiological signs of moderate osteoarthrosis were present in three people in Sommerkamp 1994 (see Analysis 05.07).

\section{DISCUSSION}


Our review (Handoll 2007) comparing external fixation with conservative treatment found some evidence to support the use of external fixation for dorsally displaced fractures of the distal radius in adults. This evidence was firmer for a superior anatomical outcome after external fixation but insufficient to confirm a superior overall functional or clinical result. While external fixation was associated with a high number of complications, many of these were minor and there was not enough evidence to prove or disprove a difference in more serious complications between external fixation and conservative treatment. The methods of external fixation examined in Handoll 2007 varied considerably and point to the many choices available. The current review attempts to categorise these choices and then to identify and examine the evidence available to inform such choices. Only a limited number of these choices were addressed by randomised controlled trials.

\section{Limitations of the review methods}

As this review abided by the criteria and methods set out in a published protocol, we have restricted our comments to two issues. The first is whether trials have been missed or inappropriately excluded in our search and selection processes. The second concerns decisions about pooling.

Our search was comprehensive and built on searches carried out over many years (Handoll 2003a) prior to the development of our review. It has included the handsearch of conference proceedings and checks for ongoing trials. An inclusive and benefit-of-doubt approach during trial searches has been maintained throughout by the lead author $(\mathrm{HH})$. Additionally, trial authors of unpublished trials have been sent requests for information and trial reports. It is possible that we have missed some potentially eligible trials but, if so, these may still not be suitable for inclusion, particularly if unpublished and inadequately reported. We guarded against study selection bias by the independent selection of eligible trials by all three review authors.

We decided against pooling for any of the multiple trial comparisons because of the evident heterogeneity in the study populations and interventions. Moreover, there were few outcomes in common and these were usually complications. The latter were usually poorly defined and their severity is likely to differ between trials (McKay 2001).

\section{Limitations of the review evidence}

Overall, the available evidence is limited in scope and quantity, and is of uncertain validity. The usual reservations of the reliability of evidence from small and underpowered trials apply. Especially, we were careful to avoid miss-interpreting inconclusive evidence as 'evidence of no effect'. Systematic bias, in the form of selection, performance, exclusion or assessment bias, or a combination of these could not be ruled out for any trial. However, this was much less a concern with Atroshi 2006, which was the only trial with clearly concealed treatment allocation. Another limitation was the inadequate assessment of outcome, particularly of function and in the long term. Non-validated outcome measures, such as those based on the Gartland and Werley scoring system (Gartland 1951), that combine aspects of function, pain, deformity and complications are particularly crude indicators of outcome. Considerable caution is needed when interpreting these, especially when the scores have been reduced into categories such as excellent, good, fair or poor. Many trials predated the development of validated patient functional assessment instruments such as Short Form-36 (SF-36), the Disability of the Arm, Shoulder, and Hand questionnaire (DASH) and the Patient-Rated Wrist Evaluation (PRWE) (MacDermid 2000). These help to standardise functional assessment in a meaningful way and assist interpretation (Amadio 2001). Again, Atroshi 2006 proved an exception. Questions also arise on the reliability of measures of grip strength and range of motion. A particular aspect, as related above, is the puzzling extreme values of relative grip strength and of flexion in Werber 2003.

\section{Applicability of the review evidence}

Generalising the findings of the included trials, should these be valid, is hampered by inadequate reporting of study details, such as the type and severity of the fracture, and bone quality. The variety of fracture classification systems, with associated issues of reliability and validity further complicates this area (Jupiter 1997). For example, the two fracture classifications used by trials in this review (the AO and Frykman) place different emphases on various fracture patterns and anatomical components. Studies have revealed unsatisfactory interobserver reliability and intraobserver reproducibility for both classification systems (Andersen 1996; Kreder 1996b), and neither was useful for predicting clinical outcome (Flinkkila 1998).

Surgical intervention is generally complex, with a myriad of techniques and devices available, and variation too in the overall care programmes. While, as shown in this review, trials may have aspects in common such as comparing an external fixator with pins and plaster fixation, the ways they achieve this may be very different. Should there be sufficient evidence to inform the choice inherent in such a comparison, it is only the basic question that is addressed. There remains the issue of the best way to achieve this (i.e. what fixator?).

Another aspect of surgery is surgical expertise. Results from trials involving single experienced operators, as in McQueen 1998, need to be confirmed in other situations, particularly those where the operators are, by and large, less experienced (Kapandji 1988).

\section{Comparisons}

A summary of the conclusions of effectiveness drawn from the findings of each comparison is provided in Table 7. Here, the effectiveness of each intervention relative to the 'control' interven- 
tion in each comparison is graded according to the categories of effectiveness described in Table 4. A concise summary of the participants and interventions for the nine trials is provided in Table 5.

Table 7. Category of effectiveness for variants of external fixation

\begin{tabular}{|c|c|c|c|c|}
\hline Comparison & Category & Justification & Qualifiers & Comments \\
\hline $\begin{array}{l}\text { External fixator versus } \\
\text { pins and plaster external } \\
\text { fixation }\end{array}$ & $\begin{array}{l}\text { 4: Unknown effective- } \\
\text { ness }\end{array}$ & $\begin{array}{l}\text { Not enough evidence: } \\
\text { two small flawed (e.g. } \\
\text { one was } \\
\text { quasi-randomised; and } \\
\text { one had imbalances in } \\
\text { baseline characteristics) } \\
\text { and very different (e.g. } \\
\text { study populations, inter- } \\
\text { ventions and study per- } \\
\text { formance including ex- } \\
\text { perience of participating } \\
\text { surgeons) trials. }\end{array}$ & $\begin{array}{l}\text { (1) In one trial ( } \\
\text { Hutchinson 1995) there } \\
\text { was a notable difference } \\
\text { between the two groups } \\
\text { in the types of compli- } \\
\text { cations: there were ten- } \\
\text { dencies for more serious } \\
\text { pin track infection and } \\
\text { persistent nerve injury in } \\
\text { the bridged uni-planar } \\
\text { external fixator group, } \\
\text { and for more pain or dis- } \\
\text { comfort and loss of re- } \\
\text { duction in the pins and } \\
\text { plaster group. }\end{array}$ & $\begin{array}{l}\text { Lower costs of pins and } \\
\text { plaster mentioned but } \\
\text { advantages of external } \\
\text { fixators (unimpeded ac- } \\
\text { cess to wounds, possi- } \\
\text { bility of adjustment etc) } \\
\text { also stressed. }\end{array}$ \\
\hline $\begin{array}{l}\text { Non-bridg- } \\
\text { ing versus bridging (over } \\
\text { wrist joint) external fixa- } \\
\text { tion }\end{array}$ & $\begin{array}{l}\text { 4: Unknown effective- } \\
\text { ness }\end{array}$ & $\begin{array}{l}\text { Not enough evidence: } \\
\text { three small heterogenous } \\
\text { (e.g. interventions and } \\
\text { study populations, espe- } \\
\text { cially types of fracture) } \\
\text { trials with differing con- } \\
\text { clusions. The only one } \\
\text { (Atroshi 2006) using a } \\
\text { validated functional out- } \\
\text { come mea- } \\
\text { sure (DASH) found no } \\
\text { difference in functional } \\
\text { outcome. } \\
\text { Queen } 1998 \text { found bet- } \\
\text { ter grip strength, wrist } \\
\text { flexion and anatomical } \\
\text { outcome for non-bridg- } \\
\text { ing fixation. Krishnan } \\
2003 \text { found no differ- } \\
\text { ence in outcome except } \\
\text { lower wrist flexion with } \\
\text { non-bridging, }\end{array}$ & $\begin{array}{l}\text { For both Atroshi } 2006 \\
\text { and McQueen 1998, the } \\
\text { distal fracture fragments } \\
\text { needed to be sufficiently } \\
\text { sized for placement of } \\
\text { the distal pins. } \\
\text { (2) McQueen } 1998 \text { in- } \\
\text { cluded redisplaced frac- } \\
\text { tures only - the major- } \\
\text { ity were extra-articular. } \\
\text { Half of the fractures were } \\
\text { extra-articular in Atroshi } \\
2006 \text { and the majority } \\
\text { were complex intra-ar- } \\
\text { ticular fractures in Krish- } \\
\text { nan } 2003 \text {. } \\
\text { (2) McQueen } 1998 \text { was } \\
\text { a single surgeon trial; the } \\
\text { results are likely to differ } \\
\text { in other situations, such } \\
\text { as where the surgeons are } \\
\text { less experienced. }\end{array}$ & $\begin{array}{l}\text { Non-bridging enabling } \\
\text { greater wrist mobility is } \\
\text { attractive. But, while su- } \\
\text { perior results were found } \\
\text { for non-bridging fixa- } \\
\text { tion in } 1 \text { trial, this was } \\
\text { not the case for the other } \\
\text { two. }\end{array}$ \\
\hline
\end{tabular}


Table 7. Category of effectiveness for variants of external fixation (Continued)

\begin{tabular}{|c|c|c|c|c|}
\hline $\begin{array}{l}\text { Supplementary percuta- } \\
\text { neous pinning versus ex- } \\
\text { ternal fixation alone: } 5 \\
\text { pin versus } 4 \text { pin external } \\
\text { fixation }\end{array}$ & $\begin{array}{l}\text { 3: Trade off between } \\
\text { benefits and harms }\end{array}$ & $\begin{array}{l}\text { One small trial found } \\
\text { the fixing of the 'float- } \\
\text { ing' distal fragment with } \\
\text { a single pin, which was } \\
\text { then attached to the fix- } \\
\text { ator, gave superior func- } \\
\text { tional and anatomical re- } \\
\text { sults. However, the oper- } \\
\text { ation took longer and the } \\
\text { possibility of additional } \\
\text { complications from the } \\
\text { extra pin cannot be ruled } \\
\text { out. }\end{array}$ & $\begin{array}{l}\text { (1) This is just one of a } \\
\text { variety of possible tech- } \\
\text { niques for supplemen- } \\
\text { tary pinning. } \\
\text { (2) The duration of } \\
\text { immobilisation was } 9 \\
\text { weeks; rather longer than } \\
\text { usual. } \\
\text { (3) An additional pin } \\
\text { was used to reduce intra- } \\
\text { articular fractures. } \\
\text { (4) All operations were } \\
\text { performed by one expe- } \\
\text { rienced surgeon: the re- } \\
\text { sults may not apply else- } \\
\text { where. }\end{array}$ & $\begin{array}{l}\text { There are some reserva- } \\
\text { tions about the reliabil- } \\
\text { ity of the evidence from } \\
\text { this trial. Additionally } \\
\text { the methods of outcome } \\
\text { assessment were not op- } \\
\text { timal. }\end{array}$ \\
\hline $\begin{array}{l}\text { Hydroxya- } \\
\text { patite coated pins versus } \\
\text { uncoated pins }\end{array}$ & $\begin{array}{l}\text { 4: Unknown effective- } \\
\text { ness }\end{array}$ & $\begin{array}{l}\text { Not enough } \\
\text { evidence: one small trial } \\
\text { that recorded few clinical } \\
\text { outcomes. }\end{array}$ & & $\begin{array}{l}\text { The clinical implications } \\
\text { of } \\
\text { the biomechanical find- } \\
\text { ing that hydroxyapatite } \\
\text { coating may help hold } \\
\text { external fixator pins in } \\
\text { osteoporotic bone dur- } \\
\text { ing external fixation are } \\
\text { not established in this } \\
\text { trial. }\end{array}$ \\
\hline
\end{tabular}

Dynamic external fixa- 4: Unknown effective- Not enough evidence: tion versus static external ness fixation. ferent trials (e.g. study two small and very difpopulations

and interventions)evaluated early wrist mobilisation in different ways. One trial (Sommerkamp 1994) was quasi-randomised and had a large loss to follow up.
(1) The five cases of As well as questions unstable or broken dy- over the reliability of namic fixator in Som- the evidence from Sommerkamp 1994 may re- merkamp 1994, there are flect some unrelated de- issues regardficiency in this device. ing the actual comparison. This was not simply early wrist mobilisation, which anyway occurred at various times, but also involved the use of two different fixators.

\section{A U THORS, CONCLUSIONS Implications for practice}

There is insufficient robust evidence to determine the relative effects of the different methods of external fixation evaluated in this review: external fixator compared with pins and plaster external fixation; non-bridged compared with bridged (over wrist joint) ex- ternal fixation; augmented external fixation involving supplementary percutaneous pinning compared with external fixation alone; hydroxyapatite coated compared with standard uncoated external fixator pins; or dynamic compared with static external fixation.

\section{Implications for research}

The evidence base for the management of distal radius fracture in adults is limited. Further research should be preceded by agree- 
ment on the priority questions for the management of these fractures, and be addressed through large multi-centre trials (Handoll 2003c).

\section{ACKNOWLEDGEMENTS}

We thank Lesley Gillespie for her help with the search strategy. We thank the following for helpful comments and input at the editorial and external review of the protocol: Bill Gillespie, Peter Herbison, Jesse Jupiter and Janet Wale. We thank the following for helpful comments and input at the editorial and external review of the review: Frank Burke, William Cooney, Bill Gillespie, Vicki Livingstone and Janet Wale. We thank Joanne Elliott and Lindsey Elstub for their help during editorial processing.

\section{REF ER E NCES}

\section{References to studies included in this review}

\section{Atroshi 2006 \{published and unpublished data\}}

Atroshi I. personal communication March 72007.

* Atroshi I, Brogren E, Larsson G-U, Kloow J, Hofer M, Berggren A-M. Wrist-bridging versus non-bridging external fixation for displaced distal radius fractures: A randomized assessor-blind clinical trial of 38 patients followed for 1 year. Acta Orthopaedica 2006;77(3):445-53.

Hutchinson 1995 \{published and unpublished data\} Hutchinson DT, Ewert GO. Pins and plaster versus external fixation in the treatment of unstable distal radius fractures: A randomized, prospective study [abstract]. Orthopaedic Transactions 1990;14(3):588-9.

* Hutchinson DT, Strenz GO, Cautilli RA. Pins and plaster vs external fixation in the treatment of unstable distal radial fractures. A randomized prospective study. Journal of Hand Surgery - British Volume 1995;20(3):365-72.

\section{Krishnan 2003 \{published and unpublished data\}}

${ }^{*}$ Krishnan J, Wigg AER, Walker RW, Slavotinek J. Intra-articular fractures of the distal radius: a prospective randomised controlled trial comparing static bridging and dynamic non-bridging external fixation. Journal of Hand Surgery - British Volume 2003; Vol. 28, issue 5:417-21.

Walker R, Wigg A, Krishnan J, Slavotinek J. Intra-articular fractures of the distal radius: A prospective randomised trial comparing bridging and non-bridging external fixation [abstract]. Journal of Bone \& Joint Surgery - British Volume 2003;85 Suppl 1:27-8.

Wigg A, Walker R, Krishnan J. Intra-articular fractures of the distal radius: Bridging vs non-bridging external fixation [abstract]. Journal of Bone and Joint Surgery - British Volume 2001;83 Suppl 3: 334-5.

Wigg A, Walker R, Krishnan J. Intra-articular fractures of the distal radius: Bridging vs non-bridging external fixation [abstract].
Journal of Bone and Joint Surgery - British Volume 2001;83 Suppl 4: 405.

Wigg A, Walker R, Krishnan J. Intra-articular fractures of the distal radius: Bridging vs non-bridging external fixation [abstract]. Journal of Bone and Joint Surgery - British Volume 2002;84 Suppl 3: 214.

McQueen 1996 \{published data only\}

McQueen MM, Court-Brown CM. Unstable fractures of the distal radius: a prospective randomized comparison of four treatment methods [abstract]. Orthopaedic Transactions 1997;21(2):595-6. * McQueen MM, Hajducka C, Court-Brown CM. Redisplaced unstable fractures of the distal radius. A prospective randomised comparison of four methods of treatment. Journal of Bone and Joint Surgery - British Volume 1996;78(3):404-9.

\section{McQueen 1998 \{published data only\}}

Casteleyn PP. Redisplaced unstable fractures of the distal radius [letter]. Journal of Bone and Joint Surgery - British Volume 1999;81 (2):368.

McQueen MM. Non-bridging external fixation of the distal radius [abstract]. Journal of Bone and Joint Surgery - British Volume 1999; 81 Suppl 2:126.

* McQueen MM. Redisplaced unstable fractures of the distal radius. A randomised, prospective study of bridging versus nonbridging external fixation. Journal of Bone and Joint Surgery - British Volume 1998;80(4):665-9.

McQueen MM, Hajducka C, Court-Brown CM. Unstable fractures of the distal radius: metaphyseal versus bridging external fixation [abstract]. Orthopaedic Transactions 1997;21(2):622-3.

\section{Moroni 2001 \{published data only\}}

Moroni A, Faldini C, Marchetti S, Manca M, Consoli V, Giannini S. Fixation in osteoporotic bone using hydroxyapatite-coated tapered external fixation pins - a prospective randomized study in wrist fractures [abstract]. Journal of Bone and Joint Surgery - British Volume 2001;83 Suppl 2:228.

Moroni A, Faldini C, Marchetti S, Manca M, Consoli V, Giannini 
S. Improvement of the bone pin interface in osteoporotic bone using hydroxyaptite-coated tapered external fixation pins. A prospective randomized clinical study in wrist. 67th Annual Meeting of the American Academy of Orthopaedic Surgeons; 2000 Mar 15-19; Orlando (FL). AAOS On-Line Service, 2000:http:// www.aaos.org/wordhtml/anmt2000/sciprog/099.htm (accessed 31/ 08/2000).

* Moroni A, Faldini C, Marchetti S, Manca M, Consoli V, Giannini S. Improvement of the bone-pin interface strength in osteoporotic bone with use of hydroxyapatite-coated tapered external-fixation pins. A prospective, randomized clinical study of wrist fractures. Journal of Bone and Joint Surgery - American Volume 2001;83-A(5):717-21.

Moroni A, Marchetti S, Manca M, Consoli V, Giannini S. Fixation improvement in osteoporotic bone using hydroxyapatite-coated tapered external fixation pins: A prospective randomized study in wrist fractures [abstract]. Journal of Bone and Joint Surgery - British Volume 2001;83 Suppl 2:229.

Raskin 1993 \{published data only\}

Raskin KB, Melone CP. Unstable articular fractures of the distal radius. Comparative techniques of ligamentotaxis. Orthopedic Clinics of North America 1993;24(2):275-86.

Sommerkamp 1994 \{published data only\}

Sommerkamp TG. Unstable distal radius fractures: A prospective randomized comparison of static versus dynamic external fixation [abstract]. Orthopaedic Transactions 1990;14(1):97-8.

* Sommerkamp TG, Seeman M, Silliman J, Jones A, Patterson S, Walker J, et al.Dynamic external fixation of unstable fractures of the distal part of the radius. A prospective, randomized comparison with static external fixation. Journal of Bone and Joint Surgery American Volume 1994;76(8):1149-61.

Werber 2003 \{published data only\}

Werber KD, Brauer R. New management in treatment of distal radius fractures using external fixation with five pins instead of four pins [abstract]. Journal of Hand Surgery - British Volume 1999;24 Suppl 1:18.

Werber KD, Brauer RB, Raeder F. New management in treatment of distal radius fracture using external fixation with five pins instead of four pins [abstract]. Journal of Hand Surgery - British Volume 1997;22 Suppl 1:58.

* Werber KD, Raeder F, Brauer RB, Weiss S. External fixation of distal radial fractures: four compared with five pins: a randomized prospective study. Journal of Bone and Joint Surgery - American Volume 2003;85-A(4):660-6.

\section{References to studies excluded from this review}

\section{Asche 1995 \{published data only\}}

* Asche G. Treatment of radius fractures with a newly developed dynamic external fixator [Die Behandlung von Speichenbruchen mit einem neu entwickelten dynamischen Bewegungsfixateur] Zentralblatt fur Chirurgie 1995;120(12):952-8.

Asche $\mathrm{G}$, Rader L, Jung K. The treatment of distal radius fractures with a newly developed movement fixator [abstract]. Journal of Bone and Joint Surgery - British Volume 1995;77 Suppl 2:149.
Auge 2000 \{published data only\}

Auge WK 2nd, Velazquez PA. The application of indirect reduction techniques in the distal radius: The role of adjuvant arthroscopy. Arthroscopy 2000;16(8):830-5.

\section{Cardone 2006 \{published data only\}}

Cardone L, Simpson H, McQueen M, Ekrol I, Muir A, McGeough $\mathrm{J}$. Technique to assess the rigidity of callus bone during external fixation of distal radial fractures [abstract]. Journal of Bone \& Joint Surgery - British Volume 2006;88 Suppl 3:396.

\section{Hutchinson 2000 \{published data only\}}

Hutchinson DT, Bachus KN, Higgenbotham T. External fixation of the distal radius: To predrill or not to predrill. Journal of Hand Surgery - American Volume 2000;25(6):1064-8.

\section{Rawes 1995 \{published and unpublished data\}} Rawes ML, Richardson JB, Hardy JRW, Dias JJ. Dynamic versus static external fixation of distal radial fractures: a prospective randomized controlled trial [abstract]. Injury 1995;26(2):140

Stoffelen 1999 \{published data only\}

* Stoffelen D, Broos P. The value of wrist arthroscopy in distal radius fractures [abstract]. Journal of Bone and Joint Surgery - British Volume 1999;81 Suppl 2:166.

Stokes 1998 \{published data only\} Stokes H, George E. Extraarticular versus transarticular external fixation of distal radius fractures [abstract]. Orthopaedic Transactions 1998;22(2):436-7.

Tortosa 1995 \{published data only\}

Tortosa RD, Chambers T. Distal radial fractures - uni-planer or multi-planer ligamentotaxis [abstract]. Orthopaedic Transactions 1995;19(3):817.

\section{References to studies awaiting assessment}

Basdekis 2005 \{published and unpublished data\}

Basdekis G, Varitimidis S, Dailiana Z, Bargiotas K, Hantes M, Malizos KN, Jones AL, Schmidt AH. Intra-articular distal radius fractures: fluoroscopic or arthroscopic reduction?[abstract]. Annual Meeting of the American Academy of Orthopaedic Surgeons; 2006 March 22-26: Chicago (IL). AAOS On-Line Service, 2006:http:// www3.aaos.org/education/anmeet/anmt2006/podium/ podium.cfm?Pevent=075 (accessed 13/09/06). Basdekis G, Varitimidis S, Dailiana Z, Hantes M, Bargiotas K, Malizos K. Intraarticular distal radius fractures: fluoroscopic or arthroscopic reduction?[abstract]. Journal of Hand Surgery - British Volume 2005;30 Suppl 1:7.

Basdekis GK, Varitimidis S, Dailiana ZH, Hantes ME, Bargiotas K, Malizos KN. Intra-articular distal radius fractures: fluoroscopic or arthroscopic reduction? [abstract]. Journal of Bone \& Joint Surgery British Volume 2006;88 Suppl 1:187.

Hove 2005 \{published data only\}

* Hove LM, Helland P, Finsen V, Revheim K, Molster AO. Dynamic versus static external fixation of fractures of the distal radius. A prospective, randomized, multicentre study [abstract]. Journal of Hand Surgery - British Volume 2005;30 Suppl 1:8-9. Hove LM, Helland P, Molster AO. Dynamic traction for unstable fractures of the distal radius. Journal of Hand Surgery - British Volume 1999;24(2):210-4. 


\section{McQueen 2006 \{unpublished data only\}}

McQueen M. External fixation with percutaneous pinning versus non-spanning external fixation verus open reduction with locked volar plate fixation for unstable distal radius fractures - a prospective randomised study. In: The National Research Register, Issue 3, 2006. Oxford: Update Software.

\section{Tornetta 2005 \{published data only\}}

Einhorn TA, Creevy WR, Levin R, Siegel J, Sung J, Tornetta PI. Reuse of external fixation components: A prospective randomized trial [abstract]. Annual Meeting of the American Academy of Orthopaedic Surgeons; 2006 March 22-26: Chicago (IL). AAOS On-Line Service, 2006:http://www3.aaos.org/education/anmeet/ anmt2006/podium/podium.cfm?Pevent=P278 (accessed 13/09/06). Tornetta P. personal correspondence March 132007.

Tornetta PI, Einhorn TA, Creevy WR, Levin R, Siegel J, Sung J. Reuse of external fixation components: A prospective randomized trial [abstract]. Orthopaedic Trauma Association Annual Meeting Oct 20-25 2005, Ottawa, Ontario. 2005:http://www.hwbf.org/ ota/am/ota05/otapa/OTA050306.htm (accessed 25/01/2006).

\section{Additional references}

\section{Altissimi 1986}

Altissimi M, Antenucci R, Fiacca C, Mancini GB. Long-term results of conservative treatment of fractures of the distal radius. Clinical Orthopaedics and Related Research 1986;(206):202-10.

Altman 2003

Altman DG, Bland JM. Interaction revisited: the difference between two estimates. BMJ 2003;326(7382):219.

\section{Amadio 2001}

Amadio PC. Outcome assessment in hand surgery and hand therapy: an update. Journal of Hand Therapy 2001;14(2):63-7.

\section{Andersen 1996}

Andersen DJ, Blair WF, Steyers CM Jr, Adams BD, el Khouri GY, Brandser EA. Classification of distal radius fractures: an analysis of interobserver reliability and intraobserver reproducibility. Journal of Hand Surgery - American Volume 1996;21(4):574-82.

\section{Atkins 1989}

Atkins RM, Duckworth T, Kanis JA. Algodystrophy following Colles' fracture. Journal of Hand Surgery - British Volume 1989;14 (2):161-4.

Atkins 2004

Atkins RM. Aspects of current management: Complex regional pain syndome. Journal of Bone \& Joint Surgery - British Volume 2004;85(8):1100-6.

\section{Belsole 1993}

Belsole RJ, Hess AV. Concomitant skeletal and soft tissue injuries. Orthopedic Clinics of North America 1993;24(2):327-31.

\section{BMJ 2006}

A guide to the text. Clinical Evidence Online http:// www.clinicalevidence.com/ceweb/about/guide.jsp (accessed 24 March 2006).

\section{Capo 2006}

Capo JT, Swan KG Jr, Tan V. External fixation techniques for distal radius fractures. Clinical Orthopaedics and Related Research 2006; 445:30-41.

\section{Chitnavis 1999}

Chitnavis J. The wrist. In: Pynsent PB, Fairbank JC, Carr AJ editor (s). Classification of musculoskeletal trauma. Oxford: Butterworth Heinemann, 1999:146-70.

\section{Cooney 1980}

Cooney WP 3rd, Dobyns JH, Linscheid RL. Complications of Colles' fractures. Journal of Bone and Joint Surgery - American Volume 1980;62(4):613-9.

\section{Cooney 1993}

Cooney WP. Fractures of the distal radius. A modern treatmentbased classification. Orthopedic Clinics of North America 1993;24 (2):211-6.

\section{Cummings 1985}

Cummings SR, Kelsey JL, Nevitt MC, O’Dowd KJ. Epidemiology of osteoporosis and osteoporotic fractures. Epidemiologic Reviews 1985;7:178-208.

\section{Fernandez 1996}

Fernandez DL, Jupiter JB. Fractures of the distal radius. A practical approach to management. 1st Edition. New York: Springer-Verlag, 1996.

\section{Fernandez 1999}

Fernandez DL, Palmer AK. Fractures of the distal radius. In: Green DP, Hotchkiss RN, Pederson WC editor(s). Green's Operative Hand Surgery. 4th Edition. New York: Churchill Livingstone, 1999: $929-85$.

Flinkkila 1998

Flinkkila T, Raatikainen T, Hamalainen M. AO and Frykman's classifications of Colles' fracture. No prognostic value in 652 patients evaluated after 5 years. Acta Orthopaedica Scandinavica 1998;69(1):77-81.

\section{Frykman 1967}

Frykman G. Fracture of the distal radius including sequelae-shoulder-hand-finger syndrome, disturbance in the distal radioulnar joint and impairment of nerve function. A clinical and experimental study. Acta Orthopaedica Scandinavica Supplementum 1967;108:3-153

\section{Gartland 1951}

Gartland JJ, Werley CW. Evaluation of healed Colles' fractures. Journal of Bone and Joint Surgery - American Volume 1951;33(4): 895-910.

\section{Handoll 2003a}

Handoll HH, Madhok R. Surgical interventions for treating distal radial fractures in adults (Cochrane review). Cochrane Database of Systematic Reviews 2003, Issue 3.

\section{Handoll 2003b}

Handoll HH, Madhok R. Conservative interventions for treating distal radial fractures in adults. Cochrane Database of Systematic Reviews 2003, Issue 2. [DOI: 10.1002/14651858.CD000314]

\section{Handoll 2003c}

Handoll HHG, Madhok R. From evidence to best practice in the management of fractures of the distal radius in adults: working towards a research agenda. BMC Musculoskeletal Disorders 2003;4 (27) 


\section{Handoll 2007}

Handoll HHG, Huntley JS, Madhok R. External fixation versus conservative treatment for distal radial fractures in adults. Cochrane Database of Systematic Reviews 2007, Issue 3. [DOI: 10.1002/ 14651858.CD006194.pub2]

\section{Higgins 2003}

Higgins JP, Thompson SG, Deeks JJ, Altman DG. Measuring inconsistency in meta-analyses. BMJ 2003;327(7414):557-60.

\section{Higgins 2005}

Higgins JPT, Green S, editors. Highly sensitive search strategies for identifying reports of randomized controlled trials in MEDLINE. Cochrane Handbook for Systematic Reviews of Interventions 4.2.5 [updated May 2005]; Appendix 5b. In: The Cochrane Library, Issue 3, 2005. Chichester, UK: John Wiley \& Sons, Ltd.

\section{Jupiter 1997}

Jupiter JB, Fernandez DL. Comparative classification for fractures of the distal end of the radius. Journal of Hand Surgery - American Volume 1997;22(4):563-71.

\section{Kapandji 1988}

Kapandji IA, Epinette J-A. Colles' fracture: treatment by double intrafocal wire fixation. In: Razemon JP, Fisk GR editor(s). The wrist. Edinburgh: Churchill Livingstone, 1988:65-73.

\section{Knirk 1986}

Knirk JL, Jupiter JB. Intra-articular fractures of the distal end of the radius in young adults. Journal of Bone and Joint Surgery - American Volume 1986;68(5):647-59.

\section{Kreder 1996a}

Kreder HJ, Hanel DP, McKee M, Jupiter J, McGillivary G, Swiontkowski MF. X-ray film measurements for healed distal radius fractures [published erratum appears in J Hand Surg [Am] 1996 May;21(3):532]. Journal of Hand Surgery - American Volume 1996; 21(1):31-9.

\section{Kreder 1996b}

Kreder HJ, Hanel DP, McKee M, Jupiter J, McGillivary G, Swiontkowski MF. Consistency of AO fracture classification for the distal radius. Journal of Bone \& Joint Surgery - British Volume 1996; 78(5):726-31.

\section{Lidstrom 1959}

Lidstrom A. Fractures of the distal end of the radius. Acta Orthopaedica Scandinavica Supplementum 1959;41:5-118.

\section{MacDermid 2000}

MacDermid JC, Richards RS, Donner A, Bellamy N, Roth JH. Responsiveness of the short form-36, disability of the arm, shoulder, and hand questionnaire, patient-rated wrist evaluation, and physical impairment measurements in evaluating recovery after a distal radius fracture. Journal of Hand Surgery - American Volume 2000;25(2):330-40.

\section{McKay 2001}

McKay SD, MacDermid JC, Roth JH, Richards RS. Assessment of complications of distal radius fractures and development of a complication checklist. Journal of Hand Surgery - American Volume 2001;26(5):916-22.

\section{Melone 1993}

Melone CPJr. Distal radius fractures: patterns of articular fragmentation. Orthopedic Clinics of North America 1993;24(2): 239-53.

\section{Muller 1991}

Muller M, Allgower M, Schneider R, Willenegger H. Manual of internal fixation: techniques recommended by the AO-ASIF Group. 3rd Edition. Berlin: Springer-Verlag, 1991.

\section{O’Neill 2001}

O’Neill TW, Cooper C, Finn JD, Lunt M, Purdie D, Reid DM, et al.Incidence of distal forearm fracture in British men and women. Osteoporosis International 2001;12(7):555-8.

\section{Older 1965}

Older TM, Stabler EV, Cassebaum WH. Colles fracture: Evaluation and selection of therapy. Journal of Trauma 1965;5(4):469-76.

\section{Pennig 1996}

Pennig D, Gausepohl T. External fixation of the wrist. Injury 1996; 27(1):1-15.

\section{Sahlin 1990}

Sahlin Y. Occurrence of fractures in a defined population: a 1-year study. Injury 1990;21(3):158-60.

\section{Singer 1998}

Singer BR, McLauchlan GJ, Robinson CM, Christie J.

Epidemiology of fractures in 15,000 adults: the influence of age and gender. Journal of Bone and Joint Surgery - British Volume 1998; 80(2):243-8.

\section{Smith 1988}

Smith RJ, Floyd WE. Smith's and Barton's fractures. In: Barton N editor(s). Fractures of the hand and wrist. Edinburgh: Churchill Livingstone, 1988:252-66.

\section{Taleisnik 1984}

Taleisnik J, Watson HK. Midcarpal instability caused by malunited fractures of the distal radius. Journal of Hand Surgery - American Volume 1984;9(3):350-7.

Temple 2004

Temple J, Santy J. Pin site care for preventing infections associated with external bone fixators and pins (Cochrane Review). Cochrane Database of Systematic Reviews 2004, Issue 1.[Art. No.: CD004551. DOI: 10.1002/14651858.CD004551.pub2]

\section{Van Staa 2001}

Van Staa TP, Dennison EM, Leufkens HG, Cooper C.

Epidemiology of fractures in England and Wales. Bone 2001;29(6): 517-22.

* Indicates the major publication for the study 
CHARACTERISTICS OF STUDIES

\author{
Characteristics of included studies [ordered by study ID]
}

Atroshi 2006

\begin{tabular}{|c|c|}
\hline Methods & $\begin{array}{l}\text { Randomised by sequentially opened numbered sealed opaque envelopes - based on computer-generated } \\
\text { list } \\
\text { Assessor blinding: yes, for physical assessment (grip strength, ROM) } \\
\text { Intention-to-treat analysis: yes } \\
\text { Loss to follow up: } 2 \text { (at } 1 \text { year) }\end{array}$ \\
\hline Participants & $\begin{array}{l}\text { Teaching (?) hospital, Sweden } \\
38 \text { participants } \\
\text { Inclusion criteria: women } 50 \text { years or older, men } 60 \text { years or older, acute dorsally displaced distal radial } \\
\text { fracture ( } 20 \text { or more degrees dorsal angulation or } 5 \mathrm{~mm} \text { or more radial shortening), extra-articular or } \\
\text { intra-articular with at least } 2 \text { large articular fragments, informed consent } \\
\text { Exclusion criteria: articular step-off }>2 \mathrm{~mm} \text {, ulnar fracture proximal to styloid, additional upper-limb } \\
\text { fractures, nerve or tendon injuries, multiple injuries, high-energy trauma (such as fall from a height), pre- } \\
\text { vious fracture in injured radius, inflammatory joint disease, cerebrovascular disease or other severe illness, } \\
\text { cognitive disorder or language problems hindering participation, drugs or alcohol abuse Classification: } \\
\text { AO (A2, A3, C2, C3: extra-articular and intra-articular) } \\
\text { Sex: } 31 \text { female } \\
\text { Age: mean } 71 \text { years, range } 55 \text { - } 86 \text { years } \\
\text { Assigned: } 19 / 19 \text { [Ext-fix - non-bridge / Ext-fix - bridge] } \\
\text { Assessed: } 18 / 18 \text { (at } 1 \text { year) }\end{array}$ \\
\hline Interventions & $\begin{array}{l}\text { Timing of intervention: within } 4 \text { days from injury. } \\
\text { Regional or general anaesthesia; intraoperative fluoroscopy. } \\
\text { (1) Non-bridging external fixation: Hoffman II compact external fixator for } 6 \text { weeks. Two longitudinally } \\
\text { parallel pins inserted via small incisions into radial shaft proximal to fracture. Two pins inserted into distal } \\
\text { fragment: transverse incision in first } 10 \text { patients, } 2 \text { longitudinal incisions in next } 9 \text { patients. After drilling, } \\
\text { two 3-mm pins inserted parallel to joint surface, fracture reduced using pins and pin clamp applied and } \\
\text { fixator locked. Patients were instructed on early motion exercises for the wrist (see below). } \\
\text { (2) Bridging external fixation: Hoffman external fixator for } 6 \text { weeks. Via small incisions, } 2 \text { longitudinally } \\
\text { parallel pins ( } 3 \mathrm{~mm} \text { ) inserted into radial shaft proximal to fracture, and } 2 \text { into } 2 \text { nd metacarpal. Closed } \\
\text { reduction. Fixator locked. } \\
\text { All patients received antibiotics (Flucloxacillin)for } 10 \text { days. Patients were instructed on early motion } \\
\text { exercises of fingers, wrist (non-bridging group only), elbow and shoulder. Patients referred to physiotherapy } \\
\text { for ROM and strengthening exercises to restore normal hand and wrist function. }\end{array}$ \\
\hline
\end{tabular}

Outcomes

Length of follow up: 1 year; also assessed at 2, 6, 10 and 26 weeks.

(1) Functional: disabilities of the arm, shoulder and hand (DASH) questionnaire (0: no disability to 100: most severe disability), SF-12 physical health score (norm = 50), mass grip strength, pain (VAS 0 to 10: worst pain), range of movement (flexion, extension, radial and ulnar deviation, pronation, supination). (2) Clinical: patient satisfaction, complications: non-union (none), pin track infection, RSD (none), tendon rupture (none), numbness associated with median nerve, transient numbness radial sensory nerve, iatrogenic fracture, redisplacement.

(3) Anatomical: X-ray at 2 and 6 weeks and 1 year. Dorsal angulation, radial inclination, radial shortening (ulnar variance), redisplacement. 
Atroshi 2006 (Continued)

Notes
$\begin{aligned} & \text { Additional information (on randomisation, surgeon experience and anaesthesia)and outcome data pro- } \\ & \text { vided by trialist }\end{aligned}$

Risk of bias

\begin{tabular}{l|ll}
\hline Item & Authors' judgement & Description \\
\hline Allocation concealment? & Yes & A - Adequate \\
\hline
\end{tabular}

\section{Hutchinson 1995}

\begin{tabular}{|c|c|}
\hline Methods & $\begin{array}{l}\text { Randomised by odd or even medical record numbers but balanced in blocks of } 4 \\
\text { Assessor blinding: not reported } \\
\text { Intention-to-treat analysis: likely at } 1 \text { year } \\
\text { Loss to follow up: } 7 \text { (at } 1 \text { year) }\end{array}$ \\
\hline Participants & $\begin{array}{l}\text { Multicentre trial in } 6 \text { university-affiliated hospitals, USA } \\
89 \text { participants with } 90 \text { fractures } \\
\text { Inclusion criteria: closed displaced unstable distal radial fractures (dorsal angulation > } 20 \text { degrees in Colles' } \\
\text { type fractures; or extensive articular involvement or severe comminution, or both) } \\
\text { Exclusion criteria: need for internal fixation (not defined) } \\
\text { Classification: Frykman [ } 86 \% 5-8 \text { ]; also Colles', Smith's, Barton's (2 fractures), chauffeur's (1 fracture) } \\
\text { and die punch. (Mainly or all intra-articular) } \\
\text { Sex: } 68 \text { female } \\
\text { Age: mean } 65 \text { years; range } 14-93 \text { years } \\
\text { Assigned: } 44 / 46 \text { (fractures)[Ext-fix / Ext-fix (POP)] } \\
\text { Assessed: } 42 / 40 \text { (at } 1 \text { year); } 26 / 26 \text { (out of } 60 \text { followed up at } 2 \text { years) }\end{array}$ \\
\hline Interventions & $\begin{array}{l}\text { Timing of intervention: not stated } \\
\text { Closed reduction under regional or general anaesthetic, usually overnight stay in hospital } \\
\text { (1) Fixator: AO small external fixator - } 2 \text { pins into radial shaft and } 2 \text { into } 2 \text { nd metacarpal (at } 45 \text { degrees) } \\
\text { - generally percutaneous insertion. } \\
\text { (2) Pins in plaster: } 2 \text { percutaneous pins - } 1 \text { threaded pin into radius proximal to fracture and } 1 \text { into the } \\
\text { metacarpals in the plane of the palm - incorporated into forearm POP. Cast trimmed to allow thumb and } \\
\text { metacarpophalangeal joint motion. } \\
\text { Fixator or pin removal } 3 \text { - } 12 \text { weeks, mean } 7.6 \text { weeks. }\end{array}$ \\
\hline
\end{tabular}

Length of follow up: 2 years; also assessed post reduction, 4 months and 1 year.
(1) Functional: subjective weakness, pain/discomfort \& functional difficulty. Overall functional grades (
Sarmiento 1975 modification of Gartland and Werley 1951). Mass grip strength, pain, range of move-
ment (flexion, extension, radial and ulnar deviation, pronation, supination), finger motion, intrinsic and
extrinsic tightness.
(2) Clinical: patient satisfaction, surgeon satisfaction. Complications: (major \& minor), pin track infec-
tion, loss of reduction, radial neuritis, RSD or RSD symptoms, CTS (present before treatment), miscella-
neous (skin breakdown, poor pin placement, aseptic pin loosening, pin related fracture, joint subluxation,
tendon adhesion), arthritis (20 of 52 patients followed up at 2 years).
(3) Anatomical: X-ray at above times. Palmar (volar) angle, radial angle, radial length, articular incongruity,
degenerative changes. 
Hutchinson 1995 (Continued)

\begin{tabular}{|c|c|c|}
\hline \multirow{2}{*}{$\begin{array}{l}\text { Notes } \\
\text { Risk of bias }\end{array}$} & \multicolumn{2}{|c|}{$\begin{array}{l}\text { Additional information (method of randomisation)and data provided by trialist. } \\
\text { Surgery performed by residents under supervision. } \\
\text { Mixed fracture population }\end{array}$} \\
\hline & & \\
\hline Item & Authors' judgement & Description \\
\hline Allocation concealment? & No & $\mathrm{C}$ - Inadequate \\
\hline
\end{tabular}

Krishnan 2003

\begin{tabular}{|c|c|}
\hline Methods & $\begin{array}{l}\text { Randomised by closed envelopes } \\
\text { Assessor blinding: not reported, independent assessment of radiographs } \\
\text { Intention-to-treat analysis: likely but not known } \\
\text { Loss to follow up: not reported }\end{array}$ \\
\hline Participants & $\begin{array}{l}\text { Teaching hospital, Australia } \\
60 \text { participants } \\
\text { Inclusion criteria: intra-articular distal radial fractures including complex comminuted fractures, informed } \\
\text { consent } \\
\text { Exclusion criteria: musculoskeletal or neurological disease, unable to follow routine pin track care, other } \\
\text { associated fractures of the hand, wrist or forearm, previous fracture of same wrist } \\
\text { Classification: AO (A3.2, B2.1, C1.1, C1.2, C1.3, C2.1, C2.2, C2.3, C3.1, C3.2, C3.3: extra-articular } \\
\text { ( } 3 \text { fractures)and intra-articular) } \\
\text { Sex: } 41 \text { female } \\
\text { Age: mean } 56 \text { years, range } 18 \text { - } 83 \text { years } \\
\text { Assigned: } 30 / 30 \text { [Ext-fix - non-bridge / Ext-fix - bridge] } \\
\text { Assessed: ?/? (at } 1 \text { year) }\end{array}$ \\
\hline Interventions & $\begin{array}{l}\text { Timing of intervention: not stated. } \\
\text { Closed reduction aided by } 5 \mathrm{~kg} \text { of horizontal finger-trap traction. Incision and open dissection to bone } \\
\text { for pin placement. } \\
\text { (1) Non-bridging external fixation: dynamic non-bridging external fixator (Delta frame). Four } 2.5 \mathrm{~mm} \\
\text { self-tapping pins placed in distal radial fragments in } 2 \text { horizontal planes: } 2 \text { into the dorso-radial aspect } \\
\text { and } 2 \text { into the dorso-ulnar aspect. (Pins transfixed the fracture fragments and supported the articular } \\
\text { surface; in cases of severe comminution and osteoporosis, these pins acted as subarticular supports.)A } 4 \\
\text { mm threaded pin was inserted into the radial shaft approximately } 6 \mathrm{~cm} \text { proximal to the fracture. Frame } \\
\text { assembled to produce a triangular shaped construct; not crossing the joint. Wrist mobilisation exercises } \\
\text { started } 2 \text { weeks postoperatively. } \\
\text { (2) Bridging external fixation: Hoffman II Compact frame: } 2 \text { self-tapping pins into distal radial shaft } \\
\text { proximal to the fracture, and } 2 \text { similar pins in the second metacarpal with one or two connecting rods } \\
\text { between them. Wrist mobilisation exercises started after fixator removal after } 6 \text { weeks. } \\
\text { All patients received antibiotics ( } 3 \text { doses cephazolin: intra-operatively and post-operatively; then } 1 \text { week } \\
\text { oral cephadine). Palmar plaster of Paris slab applied for one week. All external fixators removed at } 6 \text { weeks in } \\
\text { outpatients. Patients were instructed on finger, elbow and shoulder mobilisation exercises. Physiotherapy } \\
\text { prescribed for both groups. }\end{array}$ \\
\hline
\end{tabular}


Krishnan 2003 (Continued)

\begin{tabular}{|c|c|c|}
\hline Outcomes & \multicolumn{2}{|c|}{$\begin{array}{l}\text { Length of follow up: } 1 \text { year; also assessed at } 1,2,3,4,5,6,12 \text { and } 26 \text { weeks. } \\
\text { (1) Functional: scale of } 17 \text { activities of daily living scored as a percentage of full function, grip strength, pain } \\
\text { (VAS } 0 \text { to } 10 \text { : worst pain), range of movement (flexion, extension, radial and ulnar deviation, pronation } \\
\text { supination). } \\
\text { (2) Clinical: complications: total, pin track infection, neurological, fixation failure, RSD, EPL rupture } \\
\text { frozen shoulder, scar tethering, further surgery, redisplacement of fixator removal (none). } \\
\text { (3) Anatomical: X-ray at } 1,6,12 \text { and } 26 \text { weeks and } 1 \text { year. Dorsal angulation, radial length and angulation } \\
\text { radial step. }\end{array}$} \\
\hline Notes & \multicolumn{2}{|c|}{$\begin{array}{l}\text { One person in the bridging group with a pin track infection needed incision and drainage, and early } \\
\text { removal of the external fixator. She developed RSD and sustained a finger fracture during manipulation } \\
\text { for stiffness of the metacarpophalangeal joints. }\end{array}$} \\
\hline \multicolumn{3}{|l|}{ Risk of bias } \\
\hline Item & Authors' judgement & Description \\
\hline Allocation concealment? & Unclear & B - Unclear \\
\hline
\end{tabular}

\section{McQueen 1996}

Methods

Randomised by closed envelopes

Assessor blinding: not reported

Intention-to-treat analysis: likely

Loss to follow up: 6 (at 1 year)

\begin{tabular}{|c|c|}
\hline Participants & $\begin{array}{l}\text { Teaching hospital, UK } \\
60 \text { participants (in review comparison: see Notes) } \\
\text { Inclusion criteria: redisplaced unstable distal radial fracture (redisplaced to }>10 \text { degrees dorsal angulation } \\
\text { or radial shortening }>3 \mathrm{~mm} \text { ) } \\
\text { Exclusion criteria: inadequate primary reduction, }>2 \text { weeks from injury to recognised instability, displaced } \\
\text { articular fragments requiring open reduction, previous malunion, mental incapacity } \\
\text { Classification: AO (A and C) (extra-articular and intra-articular) } \\
\text { Sex: } 53 \text { female } \\
\text { Age: mean } 64 \text { years, range } 16 \text { - } 86 \text { years (of } 120 \text { patients) } \\
\text { Assigned: } 30 / 30 \text { [Ext-fix with early mobilisation / Ext-fix] } \\
\text { Assessed: } 26 / 28 \text { (at } 1 \text { year) }\end{array}$ \\
\hline Interventions & $\begin{array}{l}\text { Timing of intervention: under } 2 \text { weeks from injury } \\
\text { (1) Dynamic fixation: closed reduction and Pennig external fixator. Two pins inserted into } 2 \text { nd metacarpal } \\
\text { and } 2 \text { into radial shaft using an open technique. Ball joint released at } 3 \text { weeks to allow wrist movement. } \\
\text { Fixator removed after } 6 \text { weeks. } \\
\text { (2) Static fixation: as above (1) but ball joint of fixator remained locked for } 6 \text { weeks until fixator removal. } \\
\text { Physiotherapy prescribed on "purely clinical grounds". Patients did not receive physiotherapy when the } \\
\text { fixator was in place. }\end{array}$ \\
\hline
\end{tabular}


McQueen 1996 (Continued)

\begin{tabular}{|c|c|c|}
\hline Outcomes & \multicolumn{2}{|c|}{$\begin{array}{l}\text { Length of follow up: } 1 \text { year; also assessed at } 6 \text { weeks, } 3 \text { and } 6 \text { months. } \\
\text { (1) Functional: activities of daily living (own scale), mass grip strength, other grips, pain (VAS } 0 \text { to } 10 \text { : } \\
\text { no data), range of movement (overall, flexion and extension). } \\
\text { (2) Clinical: complications: recurrent instability, malunion, pin track infection, RSD, CTS, dorsal medial } \\
\text { neuropraxia (superficial radial nerve?), EPL rupture (none), carpal collapse. } \\
\text { (3) Anatomical: X-ray at all follow-up times. Dorsal angulation, radial shortening, carpal malalignment, } \\
\text { malunion. }\end{array}$} \\
\hline Notes & \multicolumn{2}{|c|}{$\begin{array}{l}\text { Trial with } 120 \text { participants had } 4 \text { intervention groups. Excluded from this review are a) } 30 \text { participants } \\
\text { receiving open reduction and bone graft held in place with a single Kirschner wire, and b) } 30 \text { participants } \\
\text { receiving closed manipulation then forearm cast. }\end{array}$} \\
\hline \multicolumn{3}{|l|}{ Risk of bias } \\
\hline Item & Authors' judgement & Description \\
\hline Allocation concealment? & Unclear & B - Unclear \\
\hline
\end{tabular}

\section{McQueen 1998}

Methods

Randomised by closed envelopes

Assessor blinding: not reported

Intention-to-treat analysis: likely

Loss to follow up: 4 (at 1 year)

\begin{tabular}{l} 
Teaching hospital, UK \\
60 participants \\
Inclusion criteria: redisplaced unstable distal radial fracture (redisplaced to $>10$ degrees dorsal angulation \\
within forearm cast), informed consent \\
Exclusion criteria: residual dorsal angulation after primary reduction, $>2$ weeks from injury to recognised \\
instability, displaced articular fracture, previous malunion, physically or mentally unable to perform \\
functional evaluation, fracture with < 1 cm of intact volar cortex on the distal radial fragment \\
Classification: AO (A3.2, A3.3, C2.1: extra-articular and intra-articular) \\
Sex: 55 female \\
Age: mean 61 years, range $31-85$ years \\
Assigned: $30 / 30$ [Ext-fix - non-bridge / Ext-fix - bridge] \\
Assessed: $28 / 28$ (at 1 year) \\
\hline $\begin{array}{l}\text { Timing of intervention: under } 2 \text { weeks from injury } \\
\text { (1) Non-bridging external fixation: closed reduction and } 2 \text { pins inserted into distal fragment from dorsal } \\
\text { to volar with a limited open technique and } 2 \text { into radial shaft. Fracture further reduced using pins as levers } \\
\text { and Pennig external fixator completed. Fixator removed at } 6 \text { weeks. } \\
\text { (2) Bridging external fixation: closed reduction and Pennig external fixator for } 6 \text { weeks. Two pins inserted } \\
\text { into 2nd metacarpal and } 2 \text { into radial shaft using an open technique. Ball joint locked. } \\
\text { Physiotherapy prescribed as "clinically indicated". }\end{array}$
\end{tabular}


McQueen 1998 (Continued)

\begin{tabular}{|c|c|}
\hline Outcomes & $\begin{array}{l}\text { Length of follow up: } 1 \text { year; also assessed post-operatively and at } 6 \text { weeks, and } 3 \text { and } 6 \text { months. } \\
\text { (1) Functional: mass grip strength, pain (VAS } 0 \text { to } 10 \text { : worst pain), residual pain, pain site, range of } \\
\text { movement (flexion, extension, pronation, supination). } \\
\text { (2) Clinical: complications: malunion, pin track infection, carpal collapse or malalignment, RSD, EPL } \\
\text { rupture. } \\
\text { (3) Anatomical: X-ray at } 6 \text { weeks and } 1 \text { year. Dorsal angulation, radial shortening, carpal malalignment, } \\
\text { malunion. }\end{array}$ \\
\hline Notes & $\begin{array}{l}\text { Some discrepancies in the data (grip strength, complications, flexion) between abstract (McQueen 1997) } \\
\text { and report. Also some discrepancies between text and tables in report: loss in radial length, and numbers } \\
\text { with malunion (14) and those meeting definition of malunion: dorsal angulation }>10 \text { degrees (15). } \\
\text { Letter commenting on pin track infection and Kapandji pinning from Casteleyn } 1999 \text { prompted definition } \\
\text { of pin track infection from McQueen. }\end{array}$ \\
\hline
\end{tabular}

Risk of bias

\begin{tabular}{l|ll}
\hline Item & Authors' judgement & Description \\
\hline Allocation concealment? & Unclear & B - Unclear \\
\hline
\end{tabular}

\section{Moroni 2001}

Methods

Randomised using a computer generated list

Assessor blinding: not reported

Intention-to-treat analysis: likely but missing data points (1 patient?) in figure of torque results

Loss to follow up: not stated, maybe 1

Hospital, Italy
Participants 20 participants
Inclusion criteria: extra-articular distal radial fracture A2 or A3 (AO classification), female with osteoporo-
sis (bone mineral density <-2.5 T score), fracture from minor trauma, ability to communicate physical
condition, informed consent
Exclusion criteria: age < 65 years; open fracture; secondary fracture to malignant tumour, bone or soft-
tissue infection at fracture site, on chemotherapy treatment, multiple fractures, severe systemic disease
Classification: AO (A2, A3) (extra-articular)
Sex: all female
Age: mean 74.5 years
Assigned: $10 / 10$ [hydroxyapatite pins / usual pins]
Assessed: 10?/10 (at 6 weeks)
Timing of intervention: not stated
All had external fixation using a Pennig II wrist fixator: 2 pins in distal radius and 2 in 2nd metacarpal.
Pins, all tapered 3.3-3 mm thread diameter, were inserted through small incisions and positioned using
fluoroscopy and implanted after predrilling.
(1) Hydroxyapatite coated tapered pins
(2) Standard (uncoated) tapered pins
Ball joint of fixator was kept locked throughout. Pin sites were cleaned daily with saline solution. All
patients had antibiotic prophylaxis (cephalosporin)for 2 days. Fixator removed without anaesthesia at 6


Moroni 2001 (Continued)

weeks post surgery.

\begin{tabular}{l}
\hline Length of follow up: 6 weeks. \\
(1) Functional: no information. \\
(2) Clinical: complications: pin track infection, pain during pin removal (VAS scores (0 to 10: maximum \\
pain), RSD. \\
(3) Anatomical: no information. \\
(4) Other: pin insertion and extraction torques. \\
\hline
\end{tabular}

Notes

Risk of bias

\begin{tabular}{l|ll}
\hline Item & Authors' judgement & Description \\
\hline Allocation concealment? & Unclear & B - Unclear \\
\hline
\end{tabular}

Raskin 1993

$\begin{array}{ll}\text { Methods } & \text { Method of randomisation not stated: “prospective random selection”. However an external fixator was } \\ \text { used for } 5 \text { people with highly comminuted fractures } \\ \text { Assessor blinding: not reported } \\ \text { Intention-to-treat analysis: no information } \\ \text { Loss to follow up: } 0 \text { (at 12+ months) }\end{array}$

Interventions

Timing of intervention: 1 to 14 days from injury, mean 6 days.

Before operation, resolution of soft tissue swelling; use of protective wrist splint immobilisation with limb elevation; continuous active motion of fingers and thumb. Closed reduction in 14 participants with severe angular deformity before external fixation. Probably regional anaesthesia used for both groups.

(1) Fixator: unilateral external fixator including a ball joint -2 threaded pins into radial shaft and 2 into 2nd metacarpal - inserted using limited open techniques and predrilling. Manipulation under traction and further reduction via percutaneous placement through the radial styloid fragment of a Kirschner wire. 5 people had open reduction. Fixator frame covered with sterile gauze at skin contact interface. Dressing changes 4 times in 8 weeks. Supplemental volar splint applied.

(2) Pins in plaster: 2 percutaneous Steinmann pins: 1 in radius proximal to fracture and 1 through 2 nd and 3rd metacarpals. Percutaneous stab incisions and use of power drill. Manipulation under traction and probably through the use of supplementary Kirschner wires inserted obliquely from radial styloid 
Raskin 1993 (Continued)

\begin{tabular}{l|l} 
& $\begin{array}{l}\text { fragment into radial shaft in most patients. Intraoperative fluoroscopy. Steinmann pins incorporated into } \\
\text { forearm plaster cast. } \\
\text { Immediate post-operative elevation and active finger movements. Fixator or pins in cast removal at } 8 \\
\text { weeks. }\end{array}$ \\
\hline Outcomes & $\begin{array}{l}\text { Length of follow up: } 12 \text { to } 60 \text { months, mean } 28 \text { months; no indication of other follow-up times. } \\
\text { (1) Functional: overall functional grades (modified McBride, and Green and O'Brien), return to former } \\
\text { activities of daily living, grip strength, range of movement (extension, flexion, pronation, supination). } \\
\text { Finger stiffness. } \\
\text { (2) Clinical: patient satisfaction. Complications: } \\
\text { pin track infection, pin loosening, pin track inflammation (not infection), pin breakage (none), osteomyeli- } \\
\text { tis (none), loss of reduction (remanipulated), persistent neuropathy (none), RSD (none), finger stiffness } \\
\text { (none), secondary operations (none). } \\
\text { (3) Anatomical: X-ray. Lidstrom 1959 grades (dorsal angulation; radial shortening). }\end{array}$ \\
\hline Notes & All 8 cases of pre-operative median nerve compression resolved with closed reduction. \\
\hline Risk of bias & \begin{tabular}{l} 
Authors' judgement \\
\hline Item
\end{tabular} \\
\hline Allocation concealment? & Unclear \\
\hline
\end{tabular}

Sommerkamp 1994

\begin{tabular}{|c|c|}
\hline Methods & $\begin{array}{l}\text { Randomised by odd or even chart number } \\
\text { Assessor blinding: not reported, independent assessment of X-rays at fixator removal } \\
\text { Intention-to-treat analysis: problems ( } 14 \text { omitted due to inadequate follow up or poor compliance to } \\
\text { rehabilitation programme; baseline characteristics were not presented for these or for the } 11 \text { lost to follow } \\
\text { up) } \\
\text { Loss to follow up: } 11 \text { lost and } 14 \text { excluded (at } 1 \text { year) }\end{array}$ \\
\hline Participants & $\begin{array}{l}\text { Teaching hospital, USA } \\
73 \text { participants with } 75 \text { fractures } \\
\text { Inclusion criteria: skeletally mature, unstable comminuted fractures of the distal radius. Either primary } \\
\text { external fixation (dorsal angulation }>20 \text { degrees or radial shortening }>10 \mathrm{~mm} \text { or intra-articular, com- } \\
\text { minuted dorsal cortex or open, bilateral, polytrauma)or post-reduction (radial shortening 11-14 mm or } \\
\text { persistent dorsal angulation)or secondary external fixation within } 14 \text { days from first reduction for failed } \\
\text { anatomical restoration (radial shortening }>5 \mathrm{~mm} \text {, loss volar tilt }>5 \text { degrees) } \\
\text { Excluded: ipsilateral fracture of scaphoid, carpal fracture-dislocation or a more proximal upper limb injury, } \\
\text { Smith's or Barton's fractures. } \\
\text { Classification: Frykman (I to VIII), extra-articular and intra-articular (mainly) } \\
\text { Sex: } 26 \text { female (of } 48 \text { analysed) } \\
\text { Age: of } 48 \text { : mean } 36 \text { years, range } 18-70 \text { years } \\
\text { Assigned: } 37 / 36 \text { (38/37 fractures) [dynamic / static Ext-fix] } \\
\text { Assessed: } 24 / 24 \text { (25/25 fractures)(at } 1 \text { year) }\end{array}$ \\
\hline
\end{tabular}




Timing of intervention: either after preliminary closed reduction (2 days) or within 14 days after an
incomplete restoration of anatomical alignment.
Anaesthesia regional or general. Closed reduction under fluoroscopy.
(1) Dynamic fixation: closed reduction + dynamic Clyburn external fixator (hinged ball-joint design): 2
pins in 2 nd metacarpal and 2 in radial shaft. Limited mobilisation (neutral to 30 degrees flexion) at around
2 weeks (actually 9 to 38 days; mean 23 days - often delayed until oedema resolved) and full mobilisation
(extension and flexion) at around 4 weeks (actually 24 to 55 days; mean 34 days). Fixator removed $6-11$
weeks (mean 10 weeks)
(2) Static fixation: closed reduction + static AO/ASIF external fixator (multiplanar): 2 pins in 2 nd
metacarpal and 2 in radial shaft. Fixator removed after $6-11$ weeks (mean 9 weeks).
Additional procedures:
Adjunctive percutaneous pinning: $3 / 2$ [dynamic / static Ext-fix]
Open reduction + bone graft: 0/1
Dressed pin sites. Post-operatively, patients were managed with active and active-assisted range of motion
exercises of the fingers, thumb, elbow and shoulder; and instructed on twice-daily care of pin tracks. Bi-
weekly assessments at the Hand Clinic.

Outcomes Length of follow up: 1 year (post fixator removal); also assessed at during fixator usage, and at fixator removal ( 10 weeks) and 1 and 6 months after that.

(1) Functional: overall score: activities of daily living including pain, disability, activity limitations ( Sarmiento modified Gartland \& Werley), grip strength, pinch strength, pain (VAS - no data), range of movement (flexion, extension, radial and ulnar deviation, pronation, supination).

(2) Clinical: complications: equipment failure (broken/unstable fixator), pin breakage, dysfunction of median nerve (due to injury), transient neuritis of superficial radial nerve, RSD, tendon rupture (none), iatrogenic fractures (none), osteomyelitis, intrinsic or extrinsic tightness, pin site problems (drainage or erythema in some cases resulting in fixator removal (3 versus 4), osteoarthritis, osteopenia (grade III: severe) on fixator removal.

(3) Anatomical: X-ray after application and after removal of fixator (10 weeks) and 1 year. Dorsal angulation, radial shortening, radial deviation, deformity (Lidstrom 1959). Angular incongruity.

Notes There was considerable variation in treatment regimens within groups.

There were small discrepancies in the data between the full report and abstract - mainly could be rounding errors - the results of the full report are used in this review.

Risk of bias

\begin{tabular}{l|ll}
\hline Item & Authors' judgement & Description \\
\hline Allocation concealment? & No & C - Inadequate \\
\hline
\end{tabular}


Werber 2003

$\begin{array}{ll}\text { Methods } & \text { Randomised via a "complete block design" } \\ \text { Assessor blinding: not reported, independent assessment of radiographs } \\ \text { Intention-to-treat analysis: likely but discrepancies in some patient characteristics and data between ab- } \\ \text { stracts and full reports } \\ \text { Loss to follow up: probably none }\end{array}$

Interventions Timing of intervention within 10 days of injury.

All fractures manipulated under local anaesthesia within 4 hours of injury and a plaster cast applied. Standard 4 pin small AO (ASIF) fixators (linear) applied under general anaesthesia and fluoroscopy. Two partially threaded $3 \mathrm{~mm}$ pins into 2 nd metacarpal and 2 partially threaded $4 \mathrm{~mm}$ pins into radial shaft. Closed reduction by traction using the distal pin. Intra-articular fractures reduced using a percutaneous Kirschner wire. Additional temporary wire inserted in some patients (12 versus 10) in distal fragment of radius to correct radial inclination.

(1) 5 pin external fixation: 5 th pin $(2.5 \mathrm{~mm}$ threaded Kirscher wire) used to fix the 'floating' distal fragment, then attached to fixator frame with a pin clamp. Pin removed after 7 weeks.

(2) 4 pin external fixation (standard external fixator)

Pin clamps on metacarpal pins loosened after 3 weeks. Fixators removed approximately 9 weeks post surgery. Physical therapy started first day after surgery. Patients advised no load bearing for at least 12 weeks. Physical therapy including range of motion exercises (fingers, wrist, elbow) continued for 8 weeks after fixator removal.

Outcomes

Length of follow up: 6 months; also 1 day and 9 weeks (fixator removal. (Also post-operatively. "On a weekly basis.": abstracts)

(1) Functional: Lidstrom rating scheme (1: unimpaired wrist function to 4: poor result, including pain), grip strength, range of movement (flexion, extension, radial and ulnar deviation, pronation, supination). (2) Clinical: treated persistent pain and swelling. Complications: pin site infection or drainage, temporary paraesthesias of thumb, index and long fingers (radial nerve?), RSD (none), tendon rupture (none), nonunion (none), nerve compression syndrome (none), fixator failure (none).

(3) Anatomical: X-ray at 1 day and 9 weeks post-operatively and 6 months. Volar tilt ('normal': 10 degrees), "relative radial length" ('normal': $0 \mathrm{~mm}$ ), (ulnar variance in abstracts), radial inclination ('normal': 30 degrees), articular step off. weeks in the 2 abstract reports. Follow up schedules and radiological results also differ.

\section{Risk of bias}


Werber 2003 (Continued)

\begin{tabular}{l|ll}
\hline Item & Authors' judgement & Description \\
\hline Allocation concealment? & Unclear & B - Unclear \\
\hline
\end{tabular}

$<$ : less than

$>$ : more than

AO: Arbeitsgemeinschaft fur Osteosynthesefragen / Association for the Study of Internal Fixation (or ASIF)

CTS: carpal tunnel syndrome

EPL: extensor pollicis longus (tendon)

Ext-fix: external fixation

K-wires: Kirschner wires

paraesthesia: numbness, tingling, "pins and needles" sensation

POP: plaster of Paris

ROM: range of movement (wrist and forearm)

RSD: reflex sympathetic dystrophy

VAS: visual analogue scale

References (listed above but not in Additional references)

*Sarmiento 1975

Sarmiento A, Pratt GW, Berry NC, Sinclair WF. Colles' fractures. Functional bracing in supination. Journal of Bone \& Joint Surgery - American Volume 1975; 57(3):311-7.

*Sarmiento 1980

Sarmiento A, Zagorski JB, Sinclair WF. Functional bracing of Colles' fractures: a prospective study of immobilization in supination vs. pronation. Clinical Orthopaedics \& Related Research 1980; 146:175-83.

Characteristics of excluded studies [ordered by study ID]

\begin{tabular}{ll} 
Asche 1995 & Not a randomised comparison. May not even be a controlled trial. \\
\hline Auge 2000 & Not a randomised comparison, nor a controlled trial. \\
\hline Cardone 2006 & $\begin{array}{l}\text { The randomised trial mentioned in a conference abstract is focused on biomechanical outcome and is yet to take } \\
\text { place (March 2007). }\end{array}$ \\
\hline Hutchinson 2000 & $\begin{array}{l}\text { Randomised trial of intervention (predrilling or not for external fixator pins) within patients: the complex study } \\
\text { design prevents the drawing of direct conclusions on clinical outcome. }\end{array}$ \\
\hline Rawes 1995 & $\begin{array}{l}\text { Quasi-randomised (based on dates of birth) trial of dynamic versus static fixation (for 6 weeks) only reported in } \\
\text { a conference abstract. Insufficient information. No response from lead trialist. Reports disuse osteoporosis (1/16 } \\
\text { versus 4/16 at 24 weeks), but no other data split by treatment group. (This was an included trial in the previous } \\
\text { review: Handoll 2003a.) }\end{array}$ \\
\hline Stoffelen 1999 & $\begin{array}{l}\text { Randomised or, more likely, quasi-randomised trial that evaluated the use of wrist arthroscopy in } 30 \text { (?) people } \\
\text { who had external fixation. Only reported in a conference abstract. Insufficient information. No response from } \\
\text { lead trialist when approached regarding another study. }\end{array}$
\end{tabular}




\section{(Continued)}

Stokes 1998 Trial involving 20 people "randomly selected" (over a 10 year period) to non-bridging (of joint) versus bridging external fixation. Only reported in a conference abstract. Insufficient information. No response from lead trialist. (This was an included trial in the previous review: Handoll 2003a.) 
DATA AND ANALYSES

Comparison 1. External fixator versus pins and plaster external fixation

\begin{tabular}{|c|c|c|c|c|}
\hline Outcome or subgroup title & $\begin{array}{l}\text { No. of } \\
\text { studies }\end{array}$ & $\begin{array}{c}\text { No. of } \\
\text { participants }\end{array}$ & Statistical method & Effect size \\
\hline $\begin{array}{l}1 \text { Functional grading: fair (or } \\
\text { poor) }\end{array}$ & 1 & & Risk Ratio (M-H, Fixed, 95\% CI) & Totals not selected \\
\hline 2 Subjective assessment of function & 1 & & Risk Ratio (M-H, Fixed, 95\% CI) & Totals not selected \\
\hline $\begin{array}{l}2.1 \text { Some pain or discomfort } \\
\text { present }\end{array}$ & 1 & & Risk Ratio (M-H, Fixed, 95\% CI) & Not estimable \\
\hline 2.2 Some functional difficulty & 1 & & Risk Ratio (M-H, Fixed, 95\% CI) & Not estimable \\
\hline 2.3 Weakness & 1 & & Risk Ratio (M-H, Fixed, 95\% CI) & Not estimable \\
\hline 3 Grip strength (\% or normal side) & 1 & & Mean Difference (IV, Fixed, 95\% CI) & Totals not selected \\
\hline 4 Complications & 2 & & Risk Ratio (M-H, Fixed, 95\% CI) & Totals not selected \\
\hline 4.1 Major complications & 1 & & Risk Ratio (M-H, Fixed, 95\% CI) & Not estimable \\
\hline $\begin{array}{l}4.2 \text { Loss of reduction resulting } \\
\text { in remanipulation }\end{array}$ & 1 & & Risk Ratio (M-H, Fixed, 95\% CI) & Not estimable \\
\hline 4.3 Loss of reduction & 1 & & Risk Ratio (M-H, Fixed, 95\% CI) & Not estimable \\
\hline $\begin{array}{l}\text { 4.4 Pin track complications: } \\
\text { infection or inflammation }\end{array}$ & 2 & & Risk Ratio (M-H, Fixed, 95\% CI) & Not estimable \\
\hline 4.5 Pin track infection: major & 1 & & Risk Ratio (M-H, Fixed, 95\% CI) & Not estimable \\
\hline $\begin{array}{l}\text { 4.6 Reflex sympathetic } \\
\text { dystropy or symptoms }\end{array}$ & 2 & & Risk Ratio (M-H, Fixed, 95\% CI) & Not estimable \\
\hline $\begin{array}{l}\text { 4.7 Reflex sympathetic } \\
\text { dystropy or symptoms: major }\end{array}$ & 1 & & Risk Ratio (M-H, Fixed, 95\% CI) & Not estimable \\
\hline 4.8 Radial neuritis & 1 & & Risk Ratio (M-H, Fixed, 95\% CI) & Not estimable \\
\hline 4.9 Radial neuritis: persistent & 2 & & Risk Ratio (M-H, Fixed, 95\% CI) & Not estimable \\
\hline 4.10 Carpal tunnel syndrome & 1 & & Risk Ratio (M-H, Fixed, 95\% CI) & Not estimable \\
\hline $\begin{array}{l}\text { 4.11 Miscellaneous } \\
\text { complications (skin } \\
\text { breakdown, pin loosening, } \\
\text { tendon adhesion etc) }\end{array}$ & 2 & & Risk Ratio (M-H, Fixed, 95\% CI) & Not estimable \\
\hline $\begin{array}{l}5 \text { Patient dissatisfaction with } \\
\text { outcome }\end{array}$ & 1 & & Risk Ratio (M-H, Fixed, 95\% CI) & Totals not selected \\
\hline 6 Anatomical grading: fair or poor & 1 & & Risk Ratio (M-H, Fixed, 95\% CI) & Totals not selected \\
\hline
\end{tabular}




\begin{tabular}{|c|c|c|c|c|}
\hline Outcome or subgroup title & $\begin{array}{l}\text { No. of } \\
\text { studies }\end{array}$ & $\begin{array}{c}\text { No. of } \\
\text { participants }\end{array}$ & Statistical method & Effect size \\
\hline $\begin{array}{l}1 \text { DASH scores ( } 0 \text { to } 100: \text { most } \\
\text { disability) }\end{array}$ & 1 & & Mean Difference (IV, Fixed, 95\% CI) & Totals not selected \\
\hline $\begin{array}{l}2 \text { SF-12 physical domain scores } \\
(0 \text { onwards; higher better: } \\
\text { population mean }=50)\end{array}$ & 1 & & Mean Difference (IV, Fixed, 95\% CI) & Totals not selected \\
\hline 3 Grip strength (kg) & 1 & & Mean Difference (IV, Fixed, 95\% CI) & Totals not selected \\
\hline $\begin{array}{l}4 \text { Mass grip strength (\% of normal } \\
\text { side) }\end{array}$ & 1 & & Mean Difference (IV, Fixed, 95\% CI) & Totals not selected \\
\hline 5 Residual pain & 2 & & Risk Ratio (M-H, Fixed, 95\% CI) & Totals not selected \\
\hline 6 Pain (VAS 0 to 100 : worst) & 1 & & Mean Difference (IV, Fixed, 95\% CI) & Totals not selected \\
\hline 7 Range of motion (degrees) & 1 & & Mean Difference (IV, Fixed, 95\% CI) & Totals not selected \\
\hline 7.1 Flexion & 1 & & Mean Difference (IV, Fixed, 95\% CI) & Not estimable \\
\hline 7.2 Extension & 1 & & Mean Difference (IV, Fixed, 95\% CI) & Not estimable \\
\hline 7.3 Radial deviation & 1 & & Mean Difference (IV, Fixed, 95\% CI) & Not estimable \\
\hline 7.4 Ulnar deviation & 1 & & Mean Difference (IV, Fixed, 95\% CI) & Not estimable \\
\hline 7.5 Pronation & 1 & & Mean Difference (IV, Fixed, 95\% CI) & Not estimable \\
\hline 7.6 Supination & 1 & & Mean Difference (IV, Fixed, 95\% CI) & Not estimable \\
\hline $\begin{array}{l}8 \text { Range of motion (\% of normal } \\
\text { side) }\end{array}$ & 1 & & Mean Difference (IV, Fixed, 95\% CI) & Totals not selected \\
\hline 8.1 Flexion & 1 & & Mean Difference (IV, Fixed, 95\% CI) & Not estimable \\
\hline 8.2 Extension & 1 & & Mean Difference (IV, Fixed, 95\% CI) & Not estimable \\
\hline 8.3 Supination & 1 & & Mean Difference (IV, Fixed, 95\% CI) & Not estimable \\
\hline 8.4 Pronation & 1 & & Mean Difference (IV, Fixed, 95\% CI) & Not estimable \\
\hline 9 Complications & 3 & & Risk Ratio (M-H, Fixed, 95\% CI) & Totals not selected \\
\hline 9.1 Fixation failure & 1 & & Risk Ratio (M-H, Fixed, 95\% CI) & Not estimable \\
\hline 9.2 Pin track infection & 3 & & Risk Ratio (M-H, Fixed, 95\% CI) & Not estimable \\
\hline $\begin{array}{l}9.3 \text { Redisplaced fracture } \\
\text { resulting in re-reduction and } \\
\text { pinning }\end{array}$ & 1 & & Risk Ratio (M-H, Fixed, 95\% CI) & Not estimable \\
\hline 9.4 Iatrogenic fracture & 1 & & Risk Ratio (M-H, Fixed, 95\% CI) & Not estimable \\
\hline $\begin{array}{l}9.5 \text { Transient numbness in } \\
\text { radial sensory nerve }\end{array}$ & 1 & & Risk Ratio (M-H, Fixed, 95\% CI) & Not estimable \\
\hline 9.6 Neurological (not defined) & 1 & & Risk Ratio (M-H, Fixed, 95\% CI) & Not estimable \\
\hline 9.7 Tendon rupture & 3 & & Risk Ratio (M-H, Fixed, 95\% CI) & Not estimable \\
\hline $\begin{array}{l}9.8 \text { Reflex sympathetic } \\
\text { dystrophy }\end{array}$ & 3 & & Risk Ratio (M-H, Fixed, 95\% CI) & Not estimable \\
\hline 9.9 Frozen shoulder & 1 & & Risk Ratio (M-H, Fixed, 95\% CI) & Not estimable \\
\hline 9.10 Scar tethering & 1 & & Risk Ratio (M-H, Fixed, 95\% CI) & Not estimable \\
\hline 9.11 Further surgery & 1 & & Risk Ratio (M-H, Fixed, 95\% CI) & Not estimable \\
\hline 9.12 Other (non-specified) & 1 & & Risk Ratio (M-H, Fixed, 95\% CI) & Not estimable \\
\hline $\begin{array}{l}10 \text { Patient dissatisfaction with } \\
\text { outcome }\end{array}$ & 1 & & Risk Ratio (M-H, Fixed, 95\% CI) & Totals not selected \\
\hline 11 Anatomical displacement & 1 & & Mean Difference (IV, Fixed, 95\% CI) & Totals not selected \\
\hline $\begin{array}{l}11.1 \text { Loss in radial length } \\
\text { (radial shortening) }(\mathrm{mm})\end{array}$ & 1 & & Mean Difference (IV, Fixed, 95\% CI) & Not estimable \\
\hline 12 Anatomical measurements & 2 & & Mean Difference (IV, Fixed, 95\% CI) & Totals not selected \\
\hline
\end{tabular}


12.1 Palmar or volar tilt

(reverse to dorsal angulation)

(degrees)

12.2 Radial inclination $\quad 1$

(degrees)

12.3 Ulnar variance $(\mathrm{mm})$

13 Deformity (structural)

13.1 Carpal malalignment

13.2 Malunion

14 Length of surgery (minutes)
Mean Difference (IV, Fixed, 95\% CI)

Not estimable

Mean Difference (IV, Fixed, 95\% CI)

Not estimable

Mean Difference (IV, Fixed, 95\% CI)

Risk Ratio (M-H, Fixed, 95\% CI)

Risk Ratio (M-H, Fixed, 95\% CI)

Risk Ratio (M-H, Fixed, 95\% CI)

Mean Difference (IV, Fixed, 95\% CI)
Not estimable

Totals not selected

Not estimable

Not estimable

Totals not selected

Comparison 3. Supplementary percutanous pinning of distal radial fracture fragment

\begin{tabular}{|c|c|c|c|c|}
\hline Outcome or subgroup title & $\begin{array}{l}\text { No. of } \\
\text { studies }\end{array}$ & $\begin{array}{c}\text { No. of } \\
\text { participants }\end{array}$ & Statistical method & Effect size \\
\hline 1 Functional gradings & 1 & & Risk Ratio (M-H, Fixed, 95\% CI) & Totals not selected \\
\hline 1.1 Not very good & 1 & & Risk Ratio (M-H, Fixed, 95\% CI) & Not estimable \\
\hline 1.2 Fair or poor & 1 & & Risk Ratio (M-H, Fixed, 95\% CI) & Not estimable \\
\hline 2 Grip strength (\% of normal side) & 1 & & Mean Difference (IV, Fixed, 95\% CI) & Totals not selected \\
\hline $\begin{array}{l}3 \text { Range of motion (\% of normal } \\
\text { side) }\end{array}$ & 1 & & Mean Difference (IV, Fixed, 95\% CI) & Totals not selected \\
\hline 3.1 Flexion & 1 & & Mean Difference (IV, Fixed, 95\% CI) & Not estimable \\
\hline 3.2 Extension & 1 & & Mean Difference (IV, Fixed, 95\% CI) & Not estimable \\
\hline 3.3 Radial deviation & 1 & & Mean Difference (IV, Fixed, 95\% CI) & Not estimable \\
\hline 3.4 Ulnar deviation & 1 & & Mean Difference (IV, Fixed, 95\% CI) & Not estimable \\
\hline 3.5 Pronation & 1 & & Mean Difference (IV, Fixed, 95\% CI) & Not estimable \\
\hline 3.6 Supination & 1 & & Mean Difference (IV, Fixed, 95\% CI) & Not estimable \\
\hline 4 Complications & 1 & & Risk Ratio (M-H, Fixed, 95\% CI) & Totals not selected \\
\hline $\begin{array}{l}\text { 4.1 Fixation failure including } \\
\text { early removal of fixator }\end{array}$ & 1 & & Risk Ratio (M-H, Fixed, 95\% CI) & Not estimable \\
\hline 4.2 Pin site problems & 1 & & Risk Ratio (M-H, Fixed, 95\% CI) & Not estimable \\
\hline 4.3 Pin loosening & 1 & & Risk Ratio (M-H, Fixed, 95\% CI) & Not estimable \\
\hline $\begin{array}{l}\text { 4.4 Persistent pain and } \\
\text { swelling (resolved after } \\
\text { medication) }\end{array}$ & 1 & & Risk Ratio (M-H, Fixed, 95\% CI) & Not estimable \\
\hline 4.5 Osteomyelitis & 1 & & Risk Ratio (M-H, Fixed, 95\% CI) & Not estimable \\
\hline 4.6 Tendon rupture & 1 & & Risk Ratio (M-H, Fixed, 95\% CI) & Not estimable \\
\hline $\begin{array}{l}4.7 \text { Nerve compression } \\
\text { syndrome }\end{array}$ & 1 & & Risk Ratio (M-H, Fixed, 95\% CI) & Not estimable \\
\hline 4.8 RSD & 1 & & Risk Ratio (M-H, Fixed, 95\% CI) & Not estimable \\
\hline 5 Ulnar plus variance & 1 & & Risk Ratio (M-H, Fixed, 95\% CI) & Totals not selected \\
\hline 6 Length of surgery (minutes) & 1 & & Mean Difference (IV, Fixed, 95\% CI) & Totals not selected \\
\hline
\end{tabular}


Comparison 4. Hydroxyapatite coated versus standard pins

\begin{tabular}{|c|c|c|c|c|}
\hline Outcome or subgroup title & $\begin{array}{l}\text { No. of } \\
\text { studies }\end{array}$ & $\begin{array}{c}\text { No. of } \\
\text { participants }\end{array}$ & Statistical method & Effect size \\
\hline 1 Complications & 1 & & Risk Ratio (M-H, Fixed, 95\% CI) & Totals not selected \\
\hline 1.1 Pin track infection & 1 & & Risk Ratio (M-H, Fixed, 95\% CI) & Not estimable \\
\hline $\begin{array}{l}1.2 \text { Reflex sympathetic } \\
\text { dystrophy }\end{array}$ & 1 & & Risk Ratio (M-H, Fixed, 95\% CI) & Not estimable \\
\hline $\begin{array}{l}2 \text { Torque for insertion and removal } \\
\text { of pins }(\mathrm{Nmm})\end{array}$ & 1 & & Mean Difference (IV, Fixed, 95\% CI) & Totals not selected \\
\hline 2.1 Insertion & 1 & & Mean Difference (IV, Fixed, 95\% CI) & Not estimable \\
\hline 2.2 Extraction & 1 & & Mean Difference (IV, Fixed, 95\% CI) & Not estimable \\
\hline
\end{tabular}

Comparison 5. Dynamic versus static fixation

\begin{tabular}{|c|c|c|c|c|}
\hline Outcome or subgroup title & $\begin{array}{l}\text { No. of } \\
\text { studies }\end{array}$ & $\begin{array}{c}\text { No. of } \\
\text { participants }\end{array}$ & Statistical method & Effect size \\
\hline 1 Functional gradings & 1 & & Risk Ratio (M-H, Fixed, 95\% CI) & Totals not selected \\
\hline 1.1 Not excellent & 1 & & Risk Ratio (M-H, Fixed, 95\% CI) & Not estimable \\
\hline 1.2 Fair or poor & 1 & & Risk Ratio (M-H, Fixed, 95\% CI) & Not estimable \\
\hline $\begin{array}{l}\text { 1.3 Fair or poor: best case for } \\
\text { dynamic fixation }\end{array}$ & 1 & & Risk Ratio (M-H, Fixed, 95\% CI) & Not estimable \\
\hline $\begin{array}{l}\text { 1.4 Fair or poor: worst case for } \\
\text { dynamic fixation }\end{array}$ & 1 & & Risk Ratio (M-H, Fixed, 95\% CI) & Not estimable \\
\hline $\begin{array}{l}2 \text { Mass grip strength ( } \% \text { of normal } \\
\text { side) }\end{array}$ & 1 & & Mean Difference (IV, Fixed, 95\% CI) & Totals not selected \\
\hline $\begin{array}{l}3 \text { Range of movement ( } \% \text { of } \\
\text { normal side) }\end{array}$ & 1 & & Mean Difference (IV, Fixed, 95\% CI) & Totals not selected \\
\hline 3.1 Overall & 1 & & Mean Difference (IV, Fixed, 95\% CI) & Not estimable \\
\hline 3.2 Flexion/extension & 1 & & Mean Difference (IV, Fixed, 95\% CI) & Not estimable \\
\hline 4 Complications & 2 & & Risk Ratio (M-H, Fixed, 95\% CI) & Totals not selected \\
\hline 4.1 Recurrent instability & 1 & & Risk Ratio (M-H, Fixed, 95\% CI) & Not estimable \\
\hline $\begin{array}{l}\text { 4.2 Loss of reduction } \\
\text { prompting re-reduction }\end{array}$ & 1 & & Risk Ratio (M-H, Fixed, 95\% CI) & Not estimable \\
\hline $\begin{array}{l}\text { 4.3 Pin track infection or } \\
\text { complications }\end{array}$ & 2 & & Risk Ratio (M-H, Fixed, 95\% CI) & Not estimable \\
\hline 4.4 Wound infection & 1 & & Risk Ratio (M-H, Fixed, 95\% CI) & Not estimable \\
\hline 4.5 Osteomyelitis of radius & 1 & & Risk Ratio (M-H, Fixed, 95\% CI) & Not estimable \\
\hline $\begin{array}{l}\text { 4.6 Pin loosening resulting in } \\
\text { early fixator removal }\end{array}$ & 1 & & Risk Ratio (M-H, Fixed, 95\% CI) & Not estimable \\
\hline 4.7 Unstable or broken fixator & 1 & & Risk Ratio (M-H, Fixed, 95\% CI) & Not estimable \\
\hline 4.8 Tendon rupture & 2 & & Risk Ratio (M-H, Fixed, 95\% CI) & Not estimable \\
\hline $\begin{array}{l}\text { 4.9 Carpal tunnel syndrome } \\
\text { or dysfunction of median nerve }\end{array}$ & 2 & & Risk Ratio (M-H, Fixed, 95\% CI) & Not estimable \\
\hline $\begin{array}{l}\text { 4.10 "Dorsal medial } \\
\text { neuropraxia" }\end{array}$ & 1 & & Risk Ratio (M-H, Fixed, 95\% CI) & Not estimable \\
\hline
\end{tabular}


4.11 Transient neuritis of superficial radial nerve

4.12 Reflex sympathetic dystrophy

4.13 Moderate or severe osteopenia at fixator removal

5 Anatomical displacement

5.1 Loss in radial length

(radial shortening) (mm)

6 Anatomical measurements

6.1 Dorsal angulation (degrees)

7 Deformity (structural)

7.1 Carpal collapse

7.2 Malunion

7.3 Moderate or severe

deformity (Lidstrom grades III

\& IV): at fixator removal

7.4 Articular incongruity (step off $>2 \mathrm{~mm}$ ): at fixator removal

7.5 Radiologically assessed osteoarthrosis (moderate or severe): at 1 year
Risk Ratio (M-H, Fixed, 95\% CI)

Risk Ratio (M-H, Fixed, 95\% CI)

Risk Ratio (M-H, Fixed, 95\% CI)

Mean Difference (IV, Fixed, 95\% CI)

Mean Difference (IV, Fixed, 95\% CI)

Mean Difference (IV, Fixed, 95\% CI)

Mean Difference (IV, Fixed, 95\% CI)

Risk Ratio (M-H, Fixed, 95\% CI)

Risk Ratio (M-H, Fixed, 95\% CI)

Risk Ratio (M-H, Fixed, 95\% CI)

Risk Ratio (M-H, Fixed, 95\% CI)

Risk Ratio (M-H, Fixed, 95\% CI)

Risk Ratio (M-H, Fixed, 95\% CI)
Not estimable

Not estimable

Not estimable

Not estimable

Totals not selected

Not estimable

Totals not selected

Not estimable

Totals not selected

Not estimable

Not estimable

Not estimable

Not estimable

\section{Analysis I.I. Comparison I External fixator versus pins and plaster external fixation, Outcome I Functional grading: fair (or poor).}

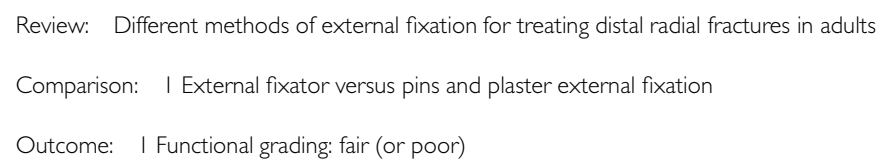

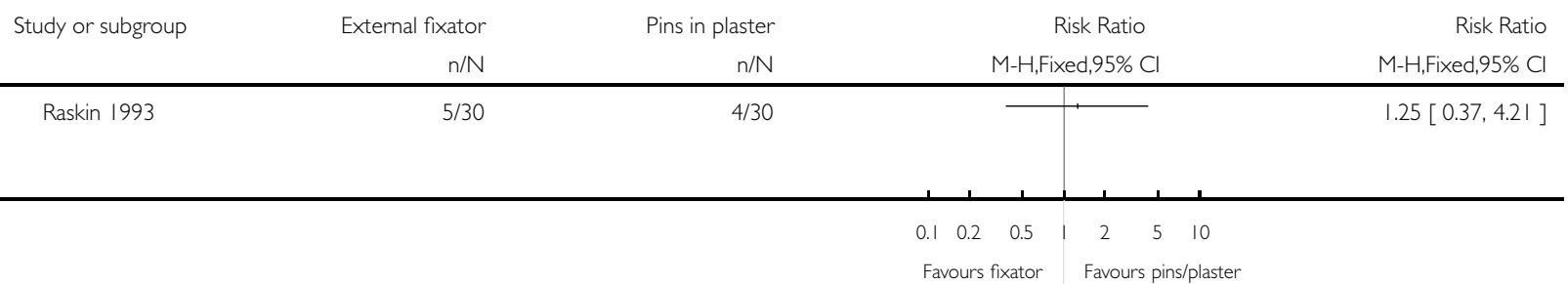


Analysis I.2. Comparison I External fixator versus pins and plaster external fixation, Outcome 2 Subjective assessment of function.

Review: Different methods of external fixation for treating distal radial fractures in adults

Comparison: I External fixator versus pins and plaster external fixation

Outcome: 2 Subjective assessment of function

Study or subgroup $\quad$ External fixator $\quad$ Pins in plaster Risk Ratio Ratio

\begin{tabular}{|c|c|c|c|c|}
\hline & $\mathrm{n} / \mathrm{N}$ & $\mathrm{n} / \mathrm{N}$ & M-H,Fixed,95\% Cl & M-H,Fixed,95\% Cl \\
\hline \multicolumn{5}{|c|}{ I Some pain or discomfort present } \\
\hline Hutchinson 1995 & $6 / 42$ & $12 / 40$ & & $0.48[0.20,1.15]$ \\
\hline \multicolumn{5}{|c|}{2 Some functional difficulty } \\
\hline Hutchinson 1995 & $3 / 42$ & $3 / 40$ & & $0.95[0.20,4.45]$ \\
\hline \multicolumn{5}{|l|}{3 Weakness } \\
\hline Hutchinson 1995 & $26 / 42$ & $26 / 40$ & $\longrightarrow$ & $0.95[0.69,1.32]$ \\
\hline
\end{tabular}

$\begin{array}{lllllll}0.1 & 0.2 & 0.5 & 1 & 2 & 5 & 10\end{array}$

Favours fixator Favours pins/plaster

Analysis 1.3. Comparison I External fixator versus pins and plaster external fixation, Outcome 3 Grip strength (\% or normal side).

Review: Different methods of external fixation for treating distal radial fractures in adults

Comparison: I External fixator versus pins and plaster external fixation

Outcome: 3 Grip strength (\% or normal side)

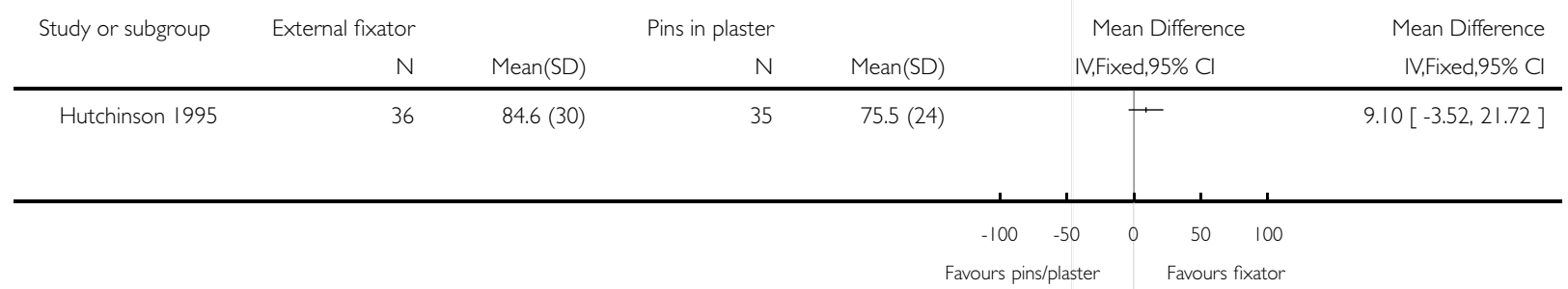




\section{Analysis I.4. Comparison I External fixator versus pins and plaster external fixation, Outcome 4 Complications.}

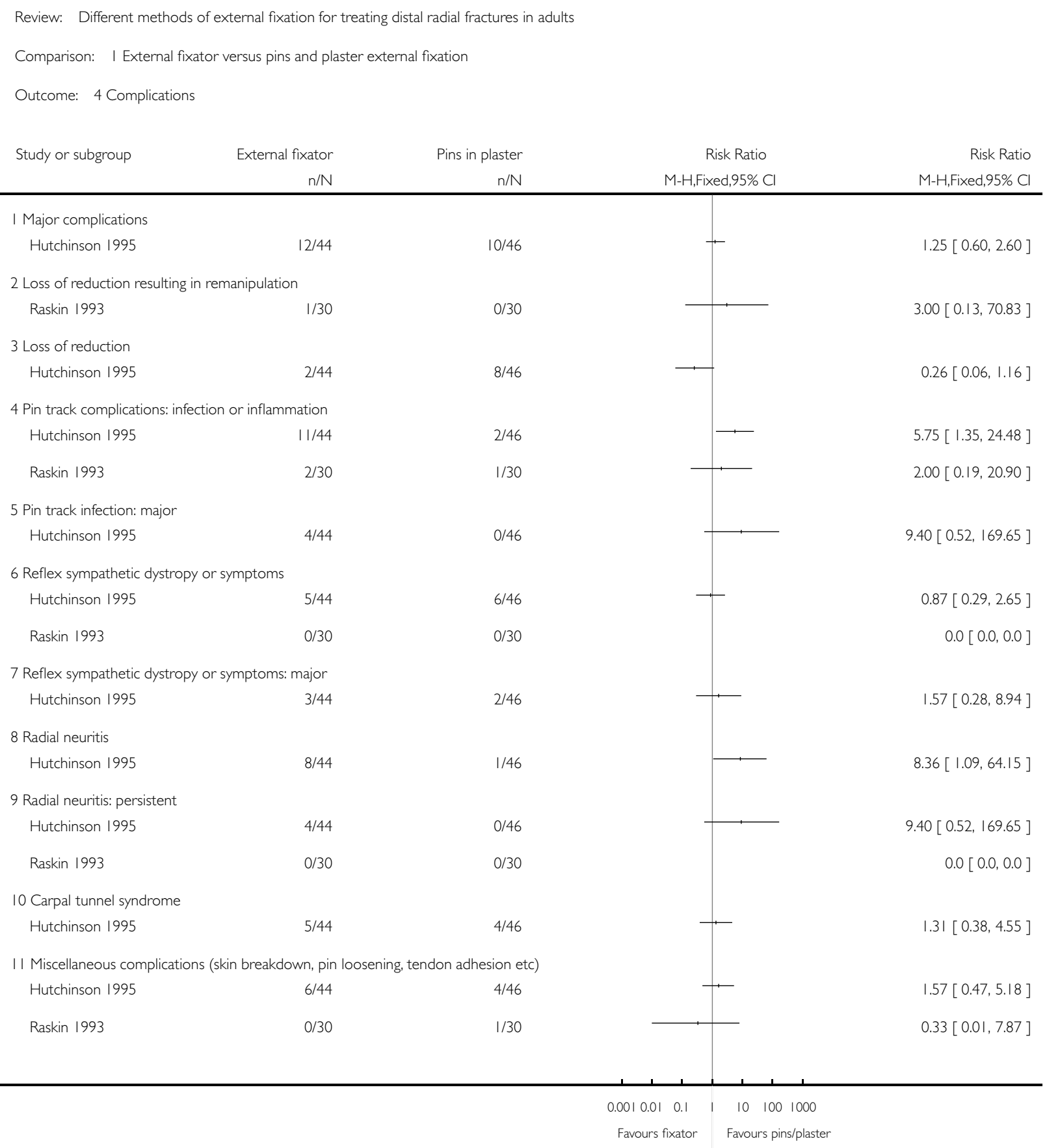


Analysis I.5. Comparison I External fixator versus pins and plaster external fixation, Outcome 5 Patient dissatisfaction with outcome.

Review: Different methods of external fixation for treating distal radial fractures in adults

Comparison: I External fixator versus pins and plaster external fixation

Outcome: 5 Patient dissatisfaction with outcome

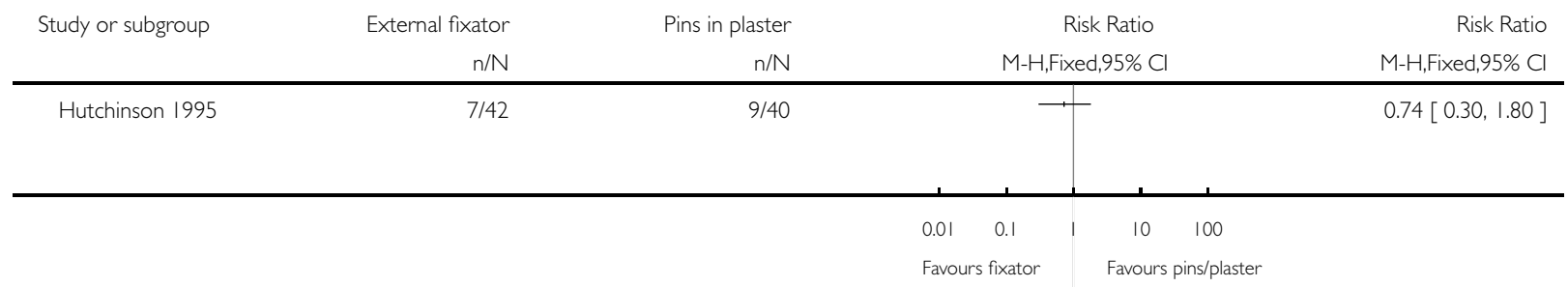

Analysis I.6. Comparison I External fixator versus pins and plaster external fixation, Outcome 6 Anatomical grading: fair or poor.

Review: Different methods of external fixation for treating distal radial fractures in adults

Comparison: I External fixator versus pins and plaster external fixation

Outcome: 6 Anatomical grading: fair or poor

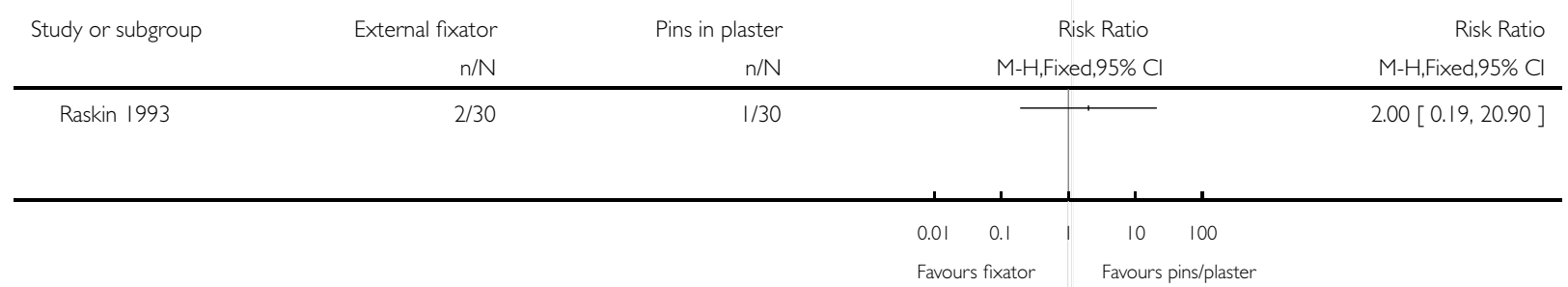


Analysis 2.I. Comparison 2 Non-bridging versus bridging external fixation, Outcome I DASH scores (0 to 100: most disability).

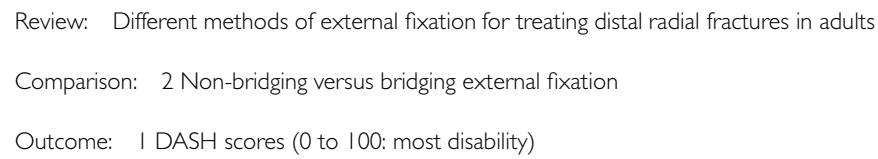

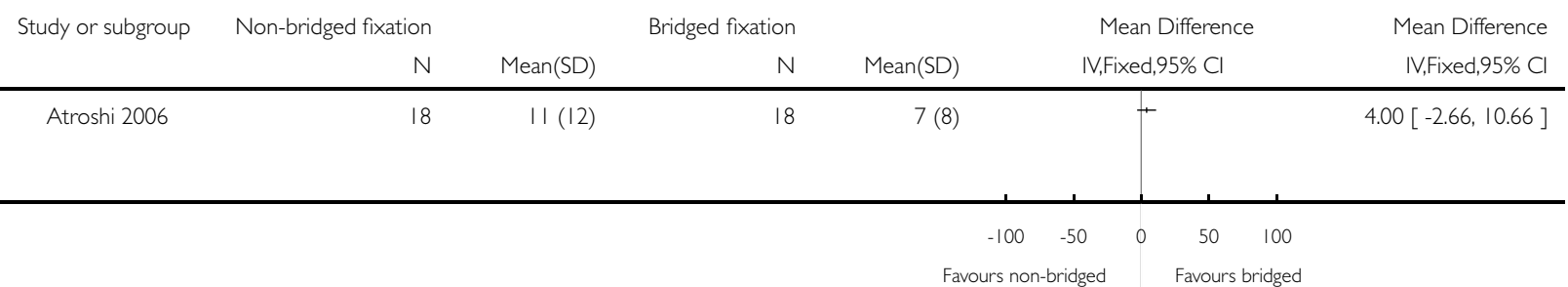

Analysis 2.2. Comparison 2 Non-bridging versus bridging external fixation, Outcome 2 SF- 12 physical domain scores ( 0 onwards; higher better: population mean $=50)$.

Review: Different methods of external fixation for treating distal radial fractures in adults

Comparison: 2 Non-bridging versus bridging external fixation

Outcome: 2 SF-12 physical domain scores ( 0 onwards; higher better: population mean $=50)$

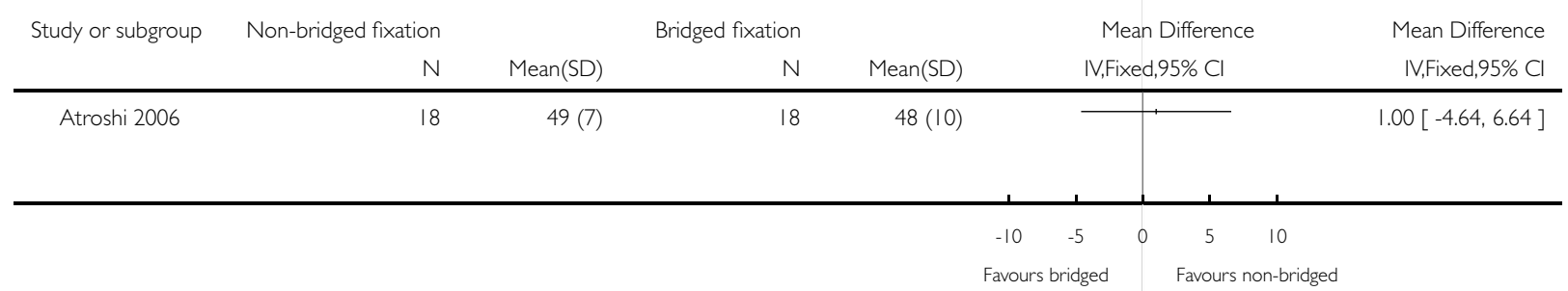




\section{Analysis 2.3. Comparison 2 Non-bridging versus bridging external fixation, Outcome 3 Grip strength (kg).}

Review: Different methods of external fixation for treating distal radial fractures in adults

Comparison: 2 Non-bridging versus bridging external fixation

Outcome: 3 Grip strength $(\mathrm{kg})$

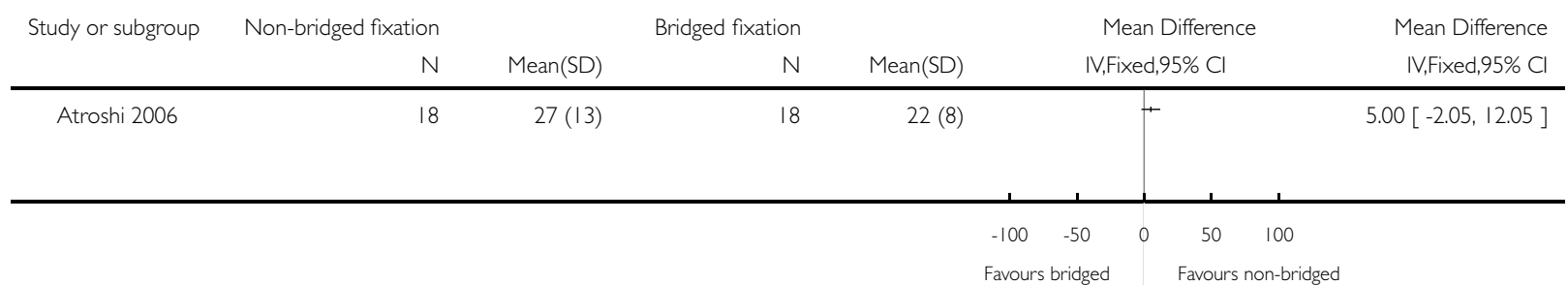

Analysis 2.4. Comparison 2 Non-bridging versus bridging external fixation, Outcome 4 Mass grip strength (\% of normal side).

Review: Different methods of external fixation for treating distal radial fractures in adults

Comparison: 2 Non-bridging versus bridging external fixation

Outcome: 4 Mass grip strength (\% of normal side)

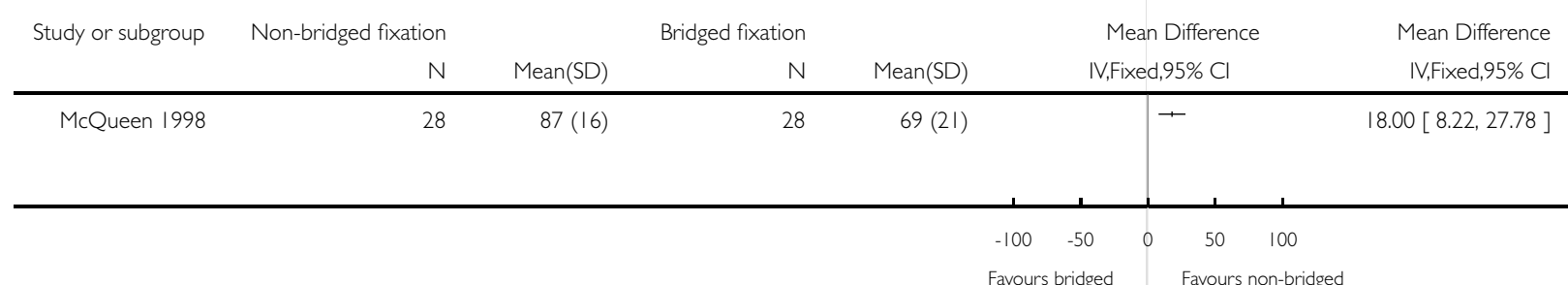


Analysis 2.5. Comparison 2 Non-bridging versus bridging external fixation, Outcome 5 Residual pain. Review: Different methods of external fixation for treating distal radial fractures in adults

Comparison: 2 Non-bridging versus bridging external fixation

Outcome: 5 Residual pain

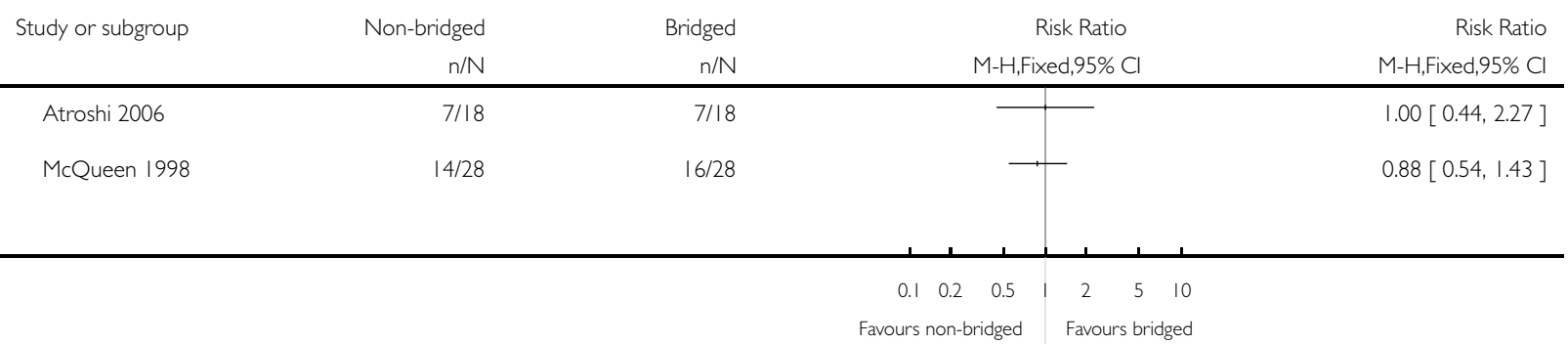

Analysis 2.6. Comparison 2 Non-bridging versus bridging external fixation, Outcome 6 Pain (VAS 0 to 100 : worst).

Review: Different methods of external fixation for treating distal radial fractures in adults

Comparison: 2 Non-bridging versus bridging external fixation

Outcome: 6 Pain (VAS 0 to 100: worst)

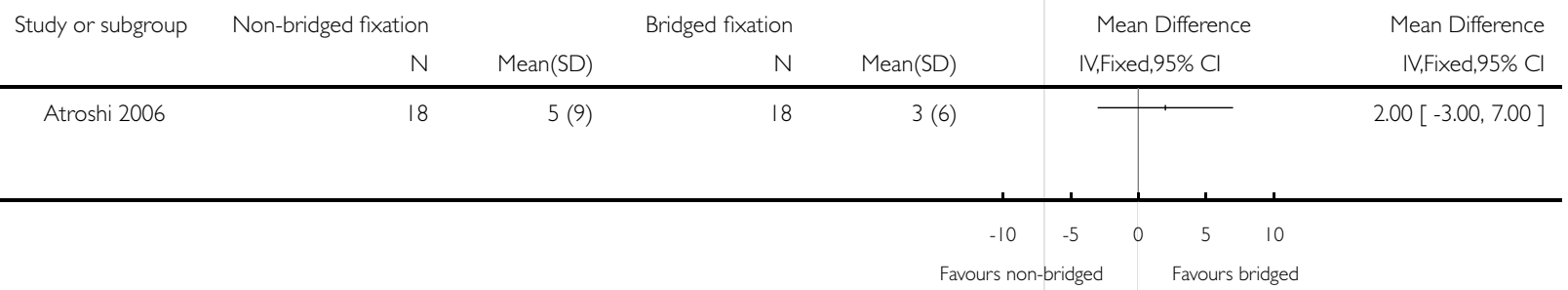


Analysis 2.7. Comparison 2 Non-bridging versus bridging external fixation, Outcome 7 Range of motion (degrees).

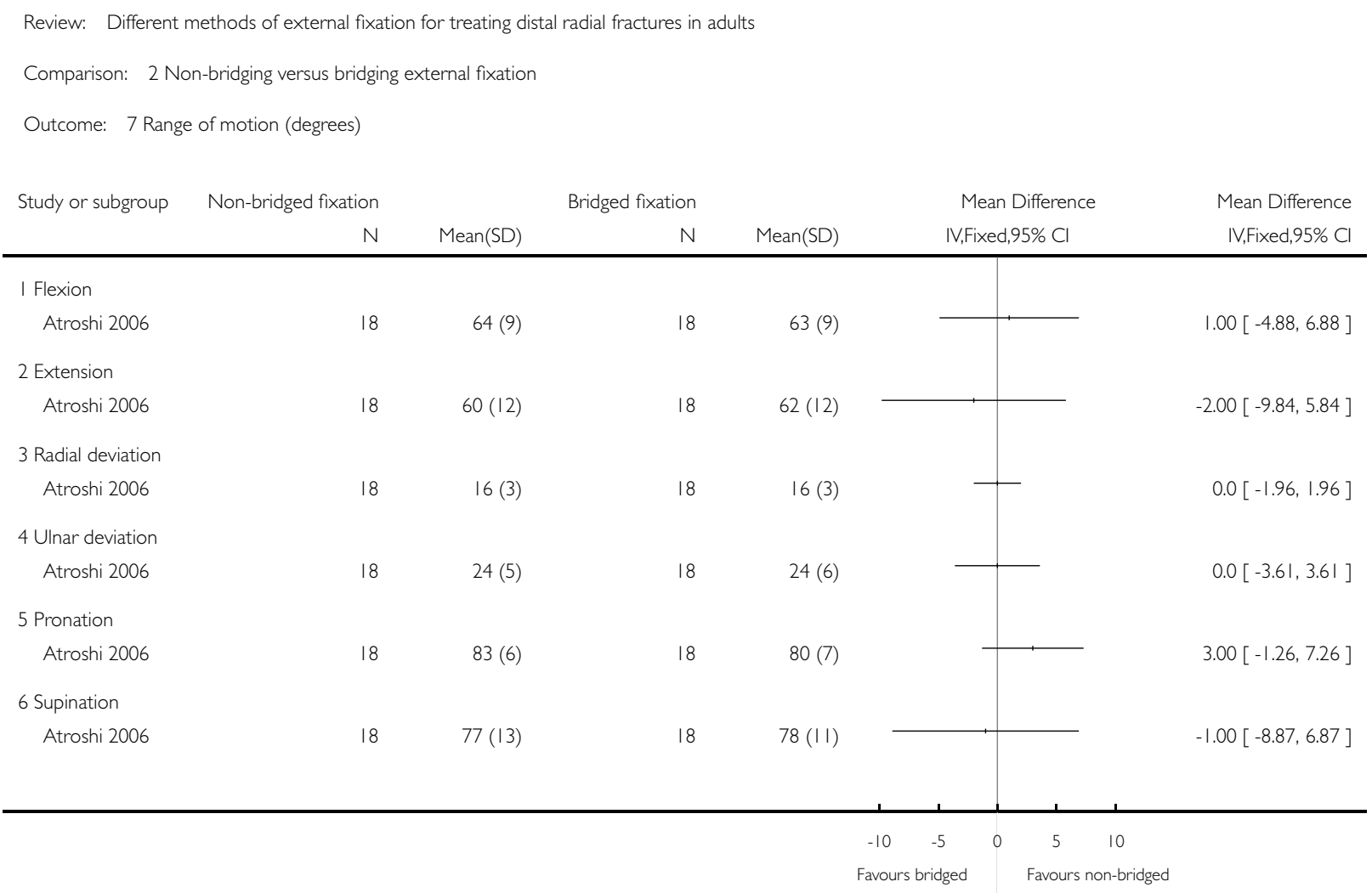


Analysis 2.8. Comparison 2 Non-bridging versus bridging external fixation, Outcome 8 Range of motion (\% of normal side).

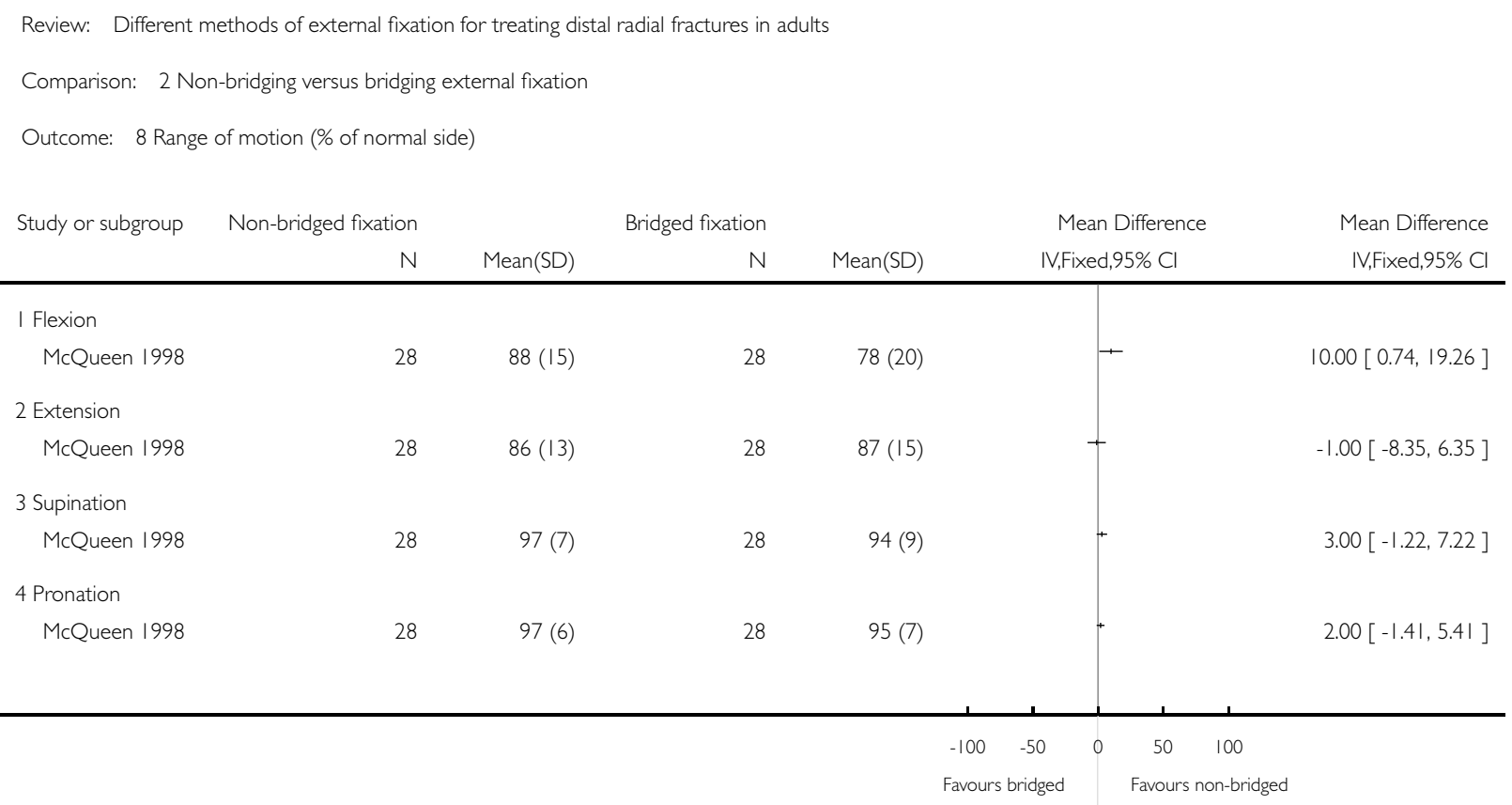


Analysis 2.9. Comparison 2 Non-bridging versus bridging external fixation, Outcome 9 Complications.

Review: Different methods of external fixation for treating distal radial fractures in adults

Comparison: 2 Non-bridging versus bridging external fixation

Outcome: 9 Complications

Study or subgroup

Non-bridged fixation

Bridged fixation

Risk Ratio

Risk Ratio

I Fixation failure

Krishnan 2003

$2 / 30$

$2 / 30$

2 Pin track infection

Atroshi 2006

$9 / 19$

$6 / 19$

Krishnan 2003

9/30

10/30

McQueen 1998

$7 / 30$

$2 / 30$

3 Redisplaced fracture resulting in re-reduction and pinning

Atroshi 2006

$0 / 19$

$1 / 19$

4 latrogenic fracture

Atroshi 2006

$0 / 19$

$2 / 19$

5 Transient numbness in radial sensory nerve

Atroshi 2006

6 Neurological (not defined)

Atroshi 2006

$1 / 19$

$2 / 19$

7 Tendon rupture

Atroshi 2006

Krishnan 2003

McQueen 1998

8 Reflex sympathetic dystrophy

Atroshi 2006

Krishnan 2003

McQueen 1998

9 Frozen shoulder

Krishnan 2003

10 Scar tethering

Krishnan 2003

I I Further surgery

Krishnan 2003

\section{$1.00[0.15,6.64]$}

$1.50[0.66,3.39]$

$0.90[0.43,1.90]$

$3.50[0.79,15.49]$

$0.33[0.01,7.70]$

$0.20[0.01,3.91]$

$0.33[0.01,7.70]$

$0.50[0.05,5.06]$

$0.0[0.0,0.0]$

$7.00[0.38,129.93]$

$5.00[0.25,99.95]$

$0.0[0.0,0.0]$

$2.00[0.19,20.90]$

$0.20[0.01,4.00]$

$1.00[0.07,15.26]$

$5.00[0.25,99.95]$

$1.00[0.15,6.64]$

$0.50[0.05,5.22]$ 
Analysis 2.10. Comparison 2 Non-bridging versus bridging external fixation, Outcome 10 Patient dissatisfaction with outcome.

Review: Different methods of external fixation for treating distal radial fractures in adults

Comparison: 2 Non-bridging versus bridging external fixation

Outcome: 10 Patient dissatisfaction with outcome

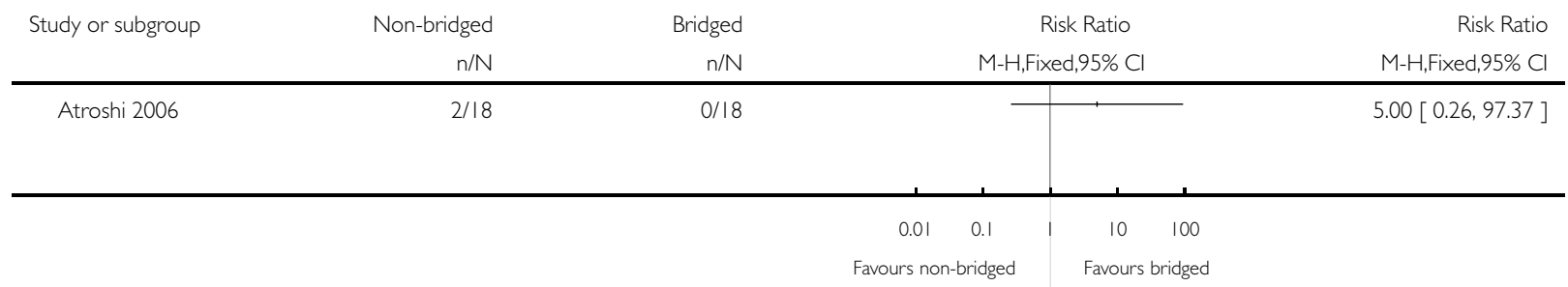

Analysis 2.1 I. Comparison 2 Non-bridging versus bridging external fixation, Outcome II Anatomical displacement.

Review: Different methods of external fixation for treating distal radial fractures in adults

Comparison: 2 Non-bridging versus bridging external fixation

Outcome: II Anatomical displacement

$\begin{array}{rrrrr}\text { Study or subgroup } & \text { Non-bridged fixation } & \text { Bridged fixation } & \text { Mean Difference } & \text { Mean Difference } \\ \text { N } & \text { Mean(SD) } & \mathrm{N} & \text { Mean(SD) } & \mathrm{IV}, \text { Fixed,95\% Cl }\end{array}$

I Loss in radial length (radial shortening) ( $\mathrm{mm}$ )

McQueen 1998

28

$1.4(1.8)$

28

$2.8(3.2)$ 
Analysis 2.12. Comparison 2 Non-bridging versus bridging external fixation, Outcome 12 Anatomical measurements.

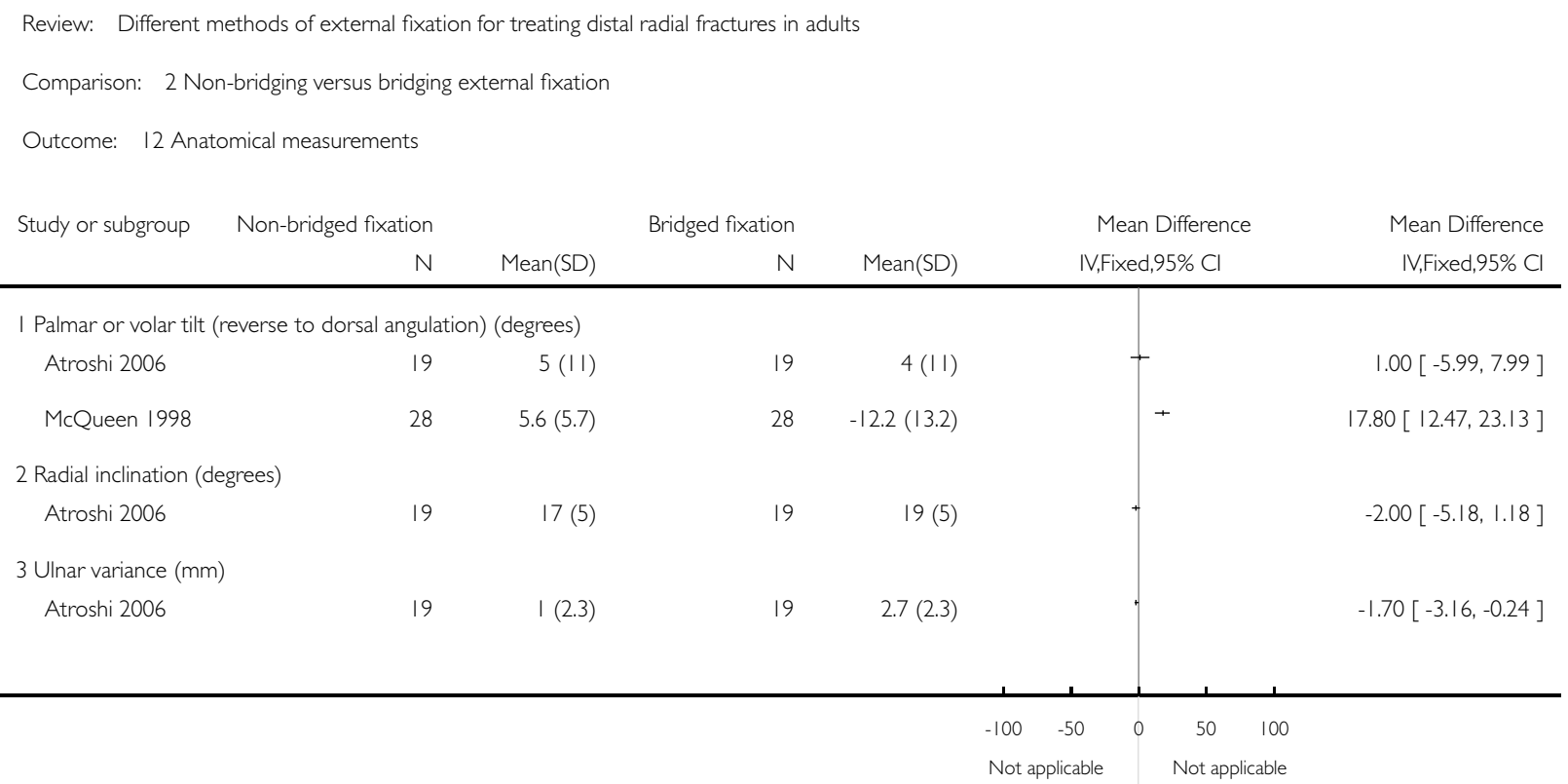

\section{Analysis 2.13. Comparison 2 Non-bridging versus bridging external fixation, Outcome 13 Deformity} (structural).

Review: Different methods of external fixation for treating distal radial fractures in adults

Comparison: 2 Non-bridging versus bridging external fixation

Outcome: 13 Deformity (structural)

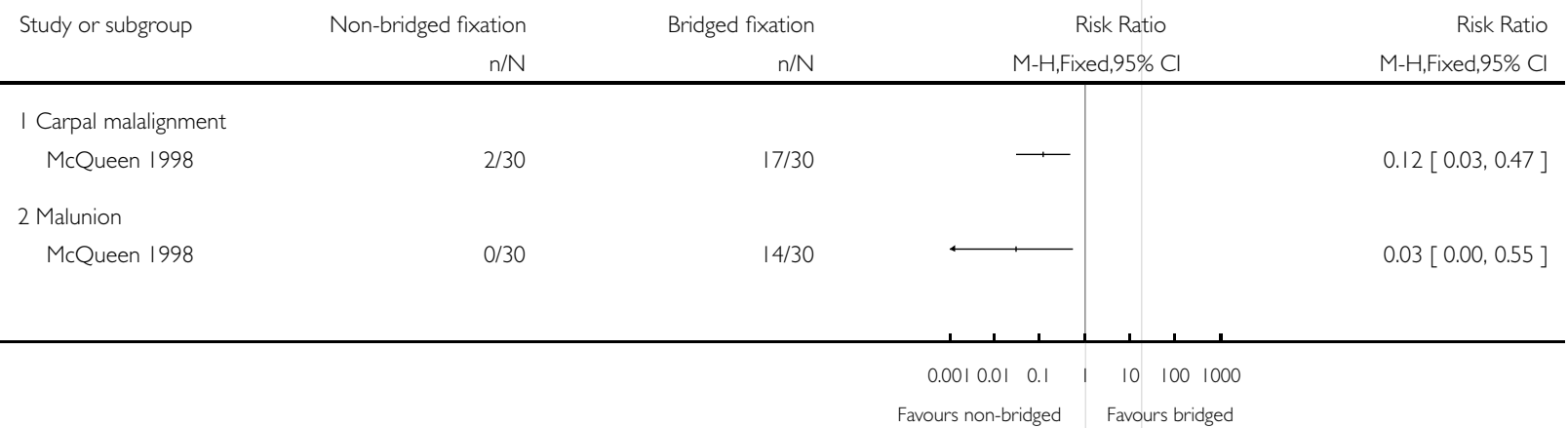


Analysis 2.14. Comparison 2 Non-bridging versus bridging external fixation, Outcome 14 Length of surgery (minutes).

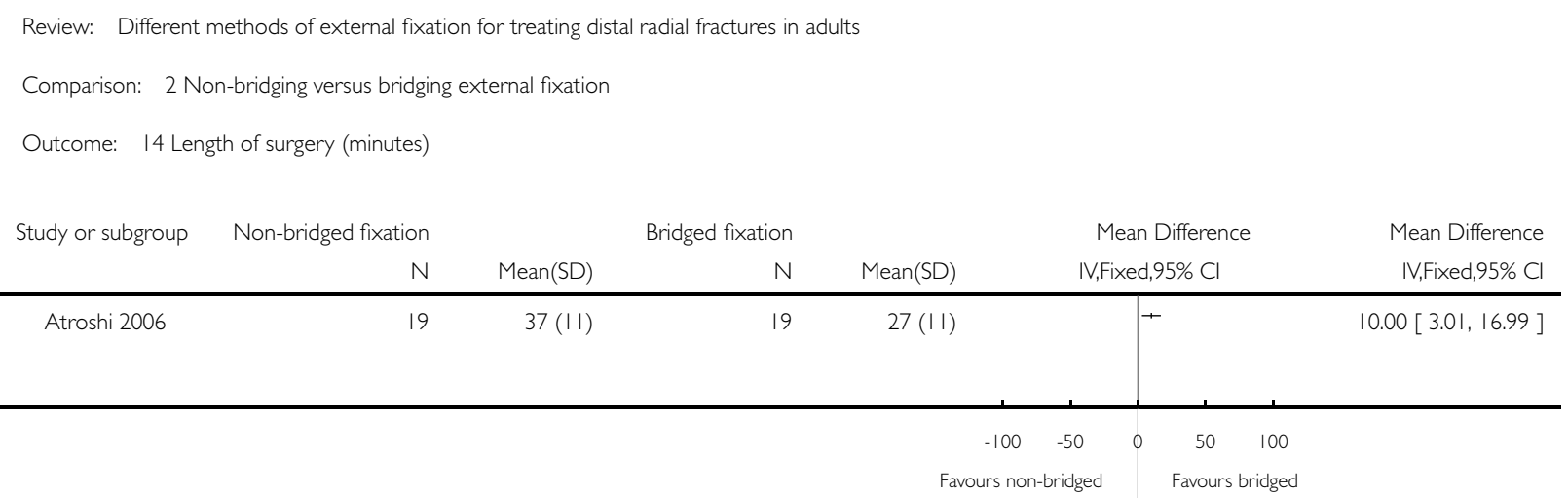

Analysis 3.1. Comparison 3 Supplementary percutanous pinning of distal radial fracture fragment, Outcome I Functional gradings.

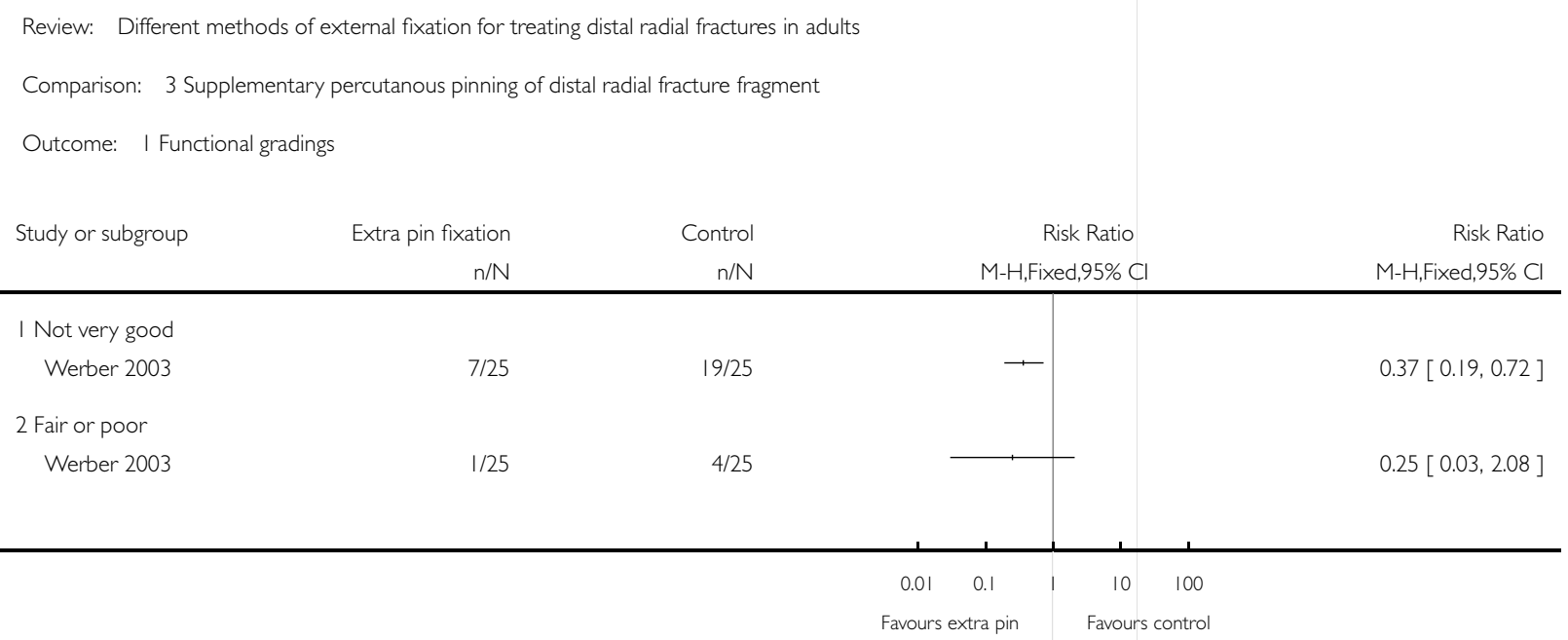


Analysis 3.2. Comparison 3 Supplementary percutanous pinning of distal radial fracture fragment, Outcome 2 Grip strength (\% of normal side).

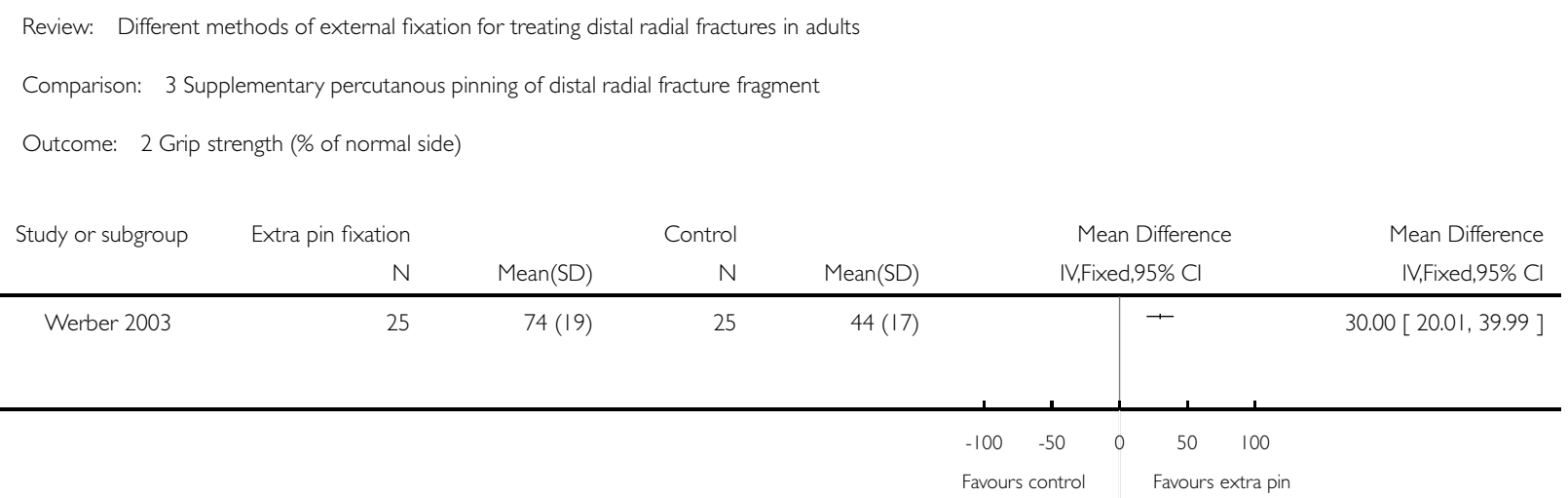

Analysis 3.3. Comparison 3 Supplementary percutanous pinning of distal radial fracture fragment, Outcome 3 Range of motion (\% of normal side).

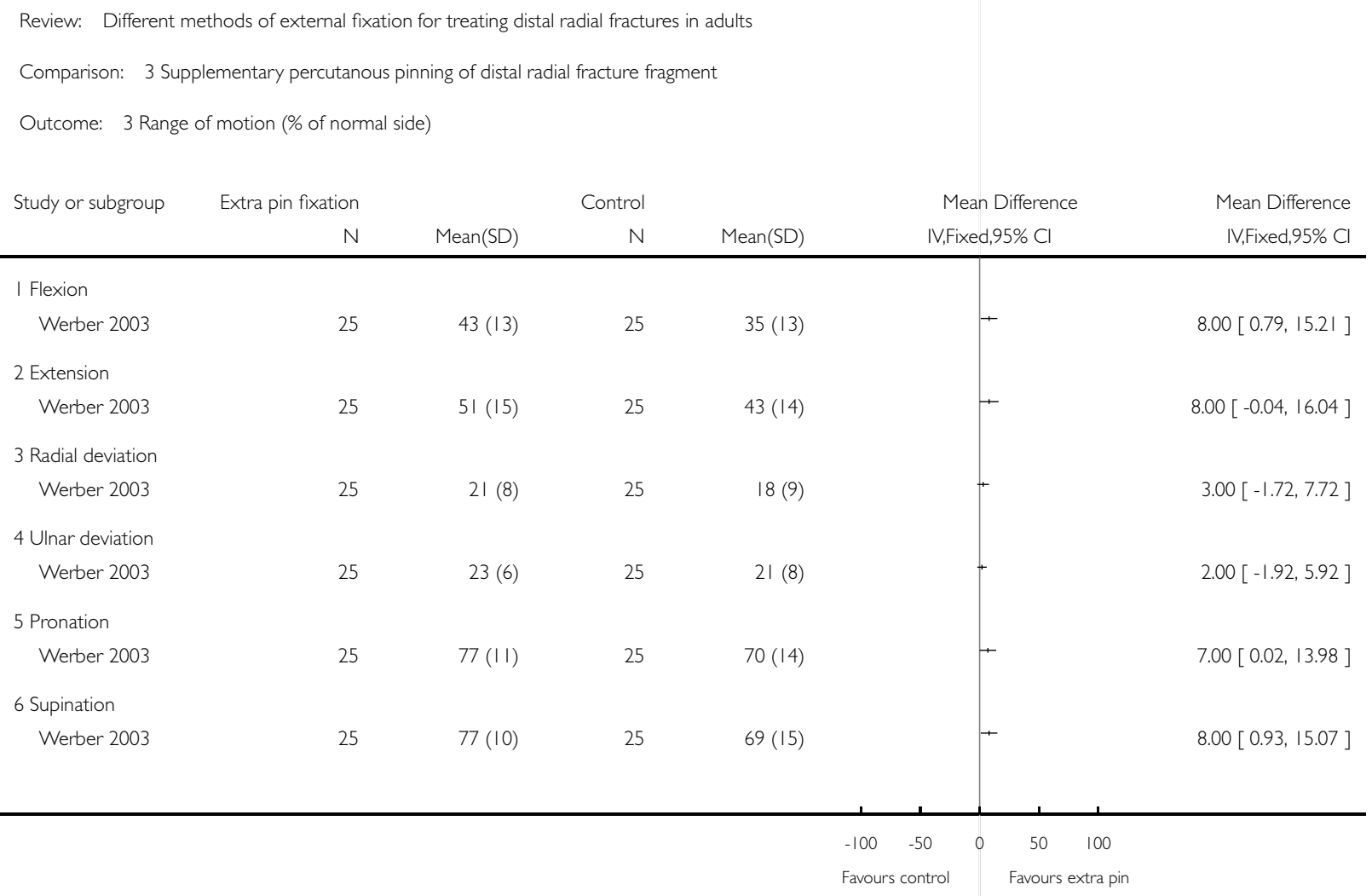


Analysis 3.4. Comparison 3 Supplementary percutanous pinning of distal radial fracture fragment, Outcome 4 Complications.

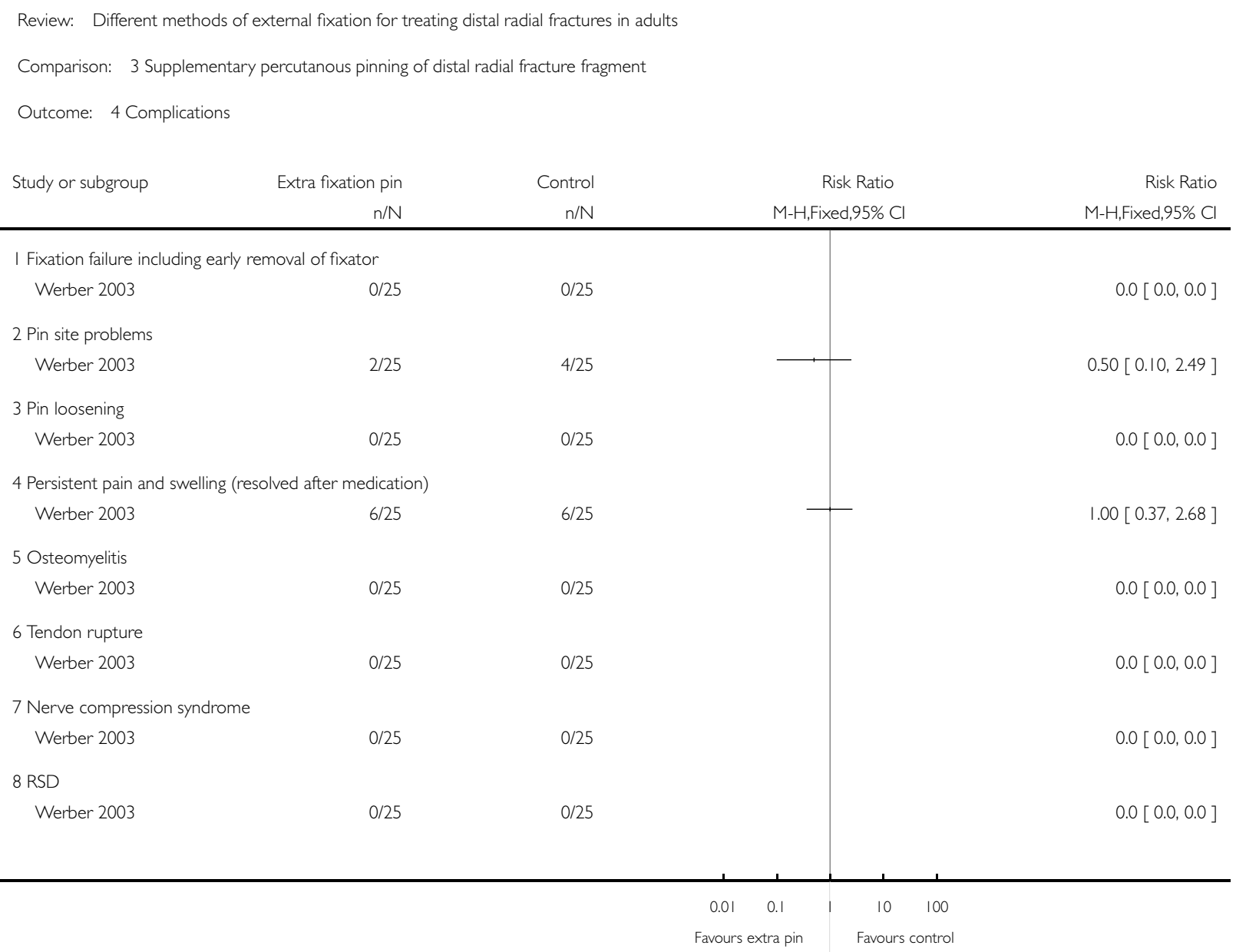


Analysis 3.5. Comparison 3 Supplementary percutanous pinning of distal radial fracture fragment, Outcome 5 Ulnar plus variance.

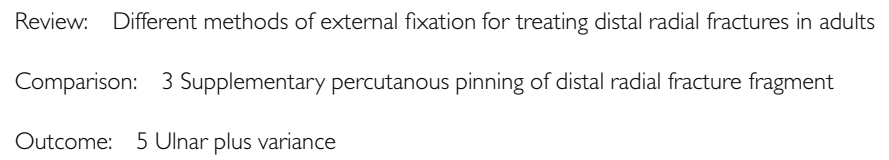

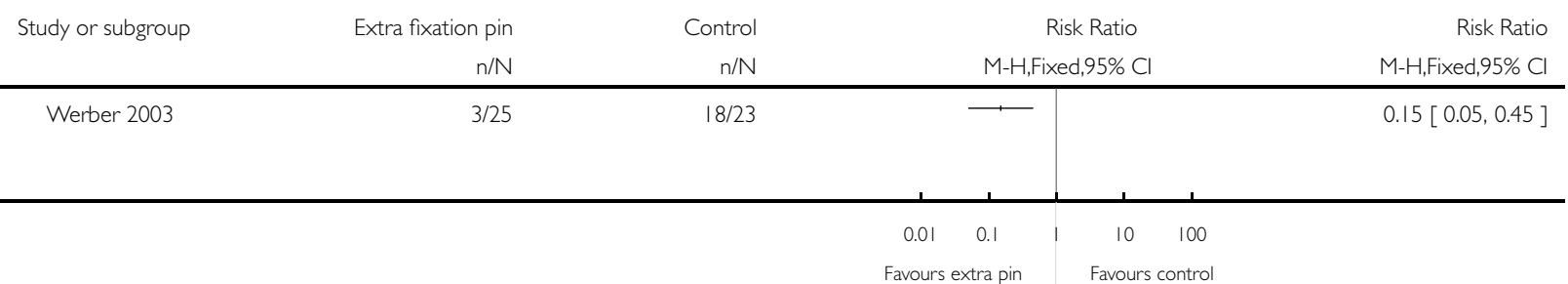

Analysis 3.6. Comparison 3 Supplementary percutanous pinning of distal radial fracture fragment, Outcome 6 Length of surgery (minutes).

Review: Different methods of external fixation for treating distal radial fractures in adults

Comparison: 3 Supplementary percutanous pinning of distal radial fracture fragment

Outcome: 6 Length of surgery (minutes)

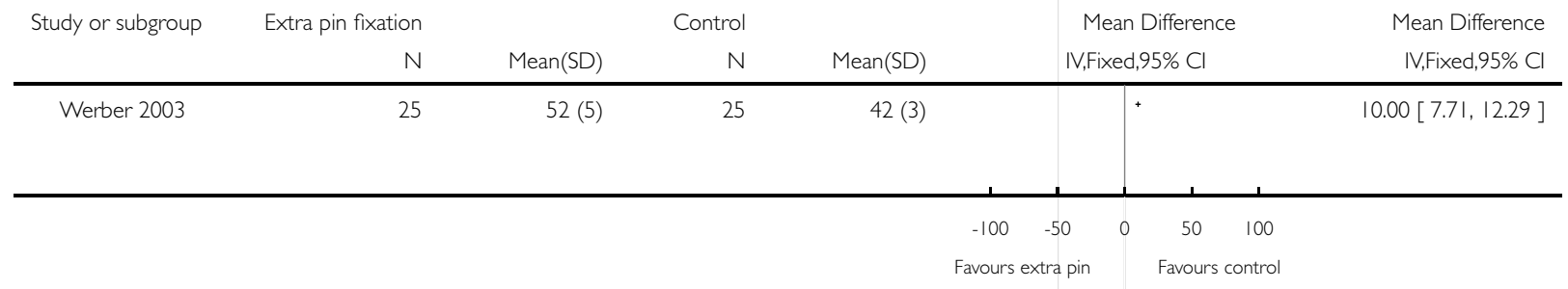


Analysis 4.I. Comparison 4 Hydroxyapatite coated versus standard pins, Outcome I Complications. Review: Different methods of external fixation for treating distal radial fractures in adults

Comparison: 4 Hydroxyapatite coated versus standard pins

Outcome: I Complications

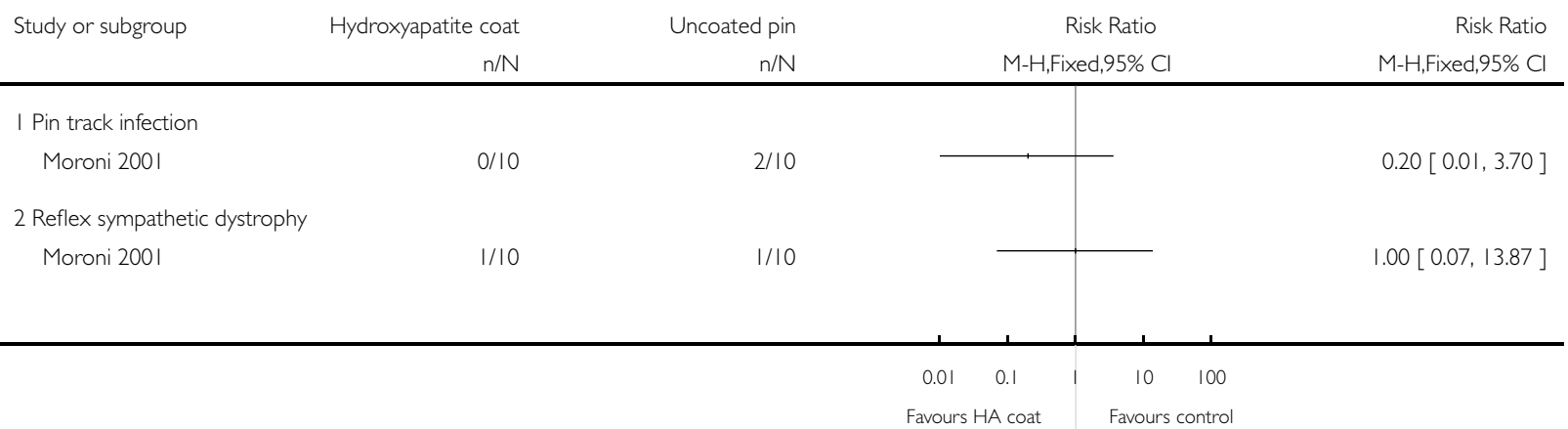

Analysis 4.2. Comparison 4 Hydroxyapatite coated versus standard pins, Outcome 2 Torque for insertion and removal of pins $(\mathbf{N m m})$.

Review: Different methods of external fixation for treating distal radial fractures in adults

Comparison: 4 Hydroxyapatite coated versus standard pins

Outcome: 2 Torque for insertion and removal of pins ( $\mathrm{Nmm}$ )

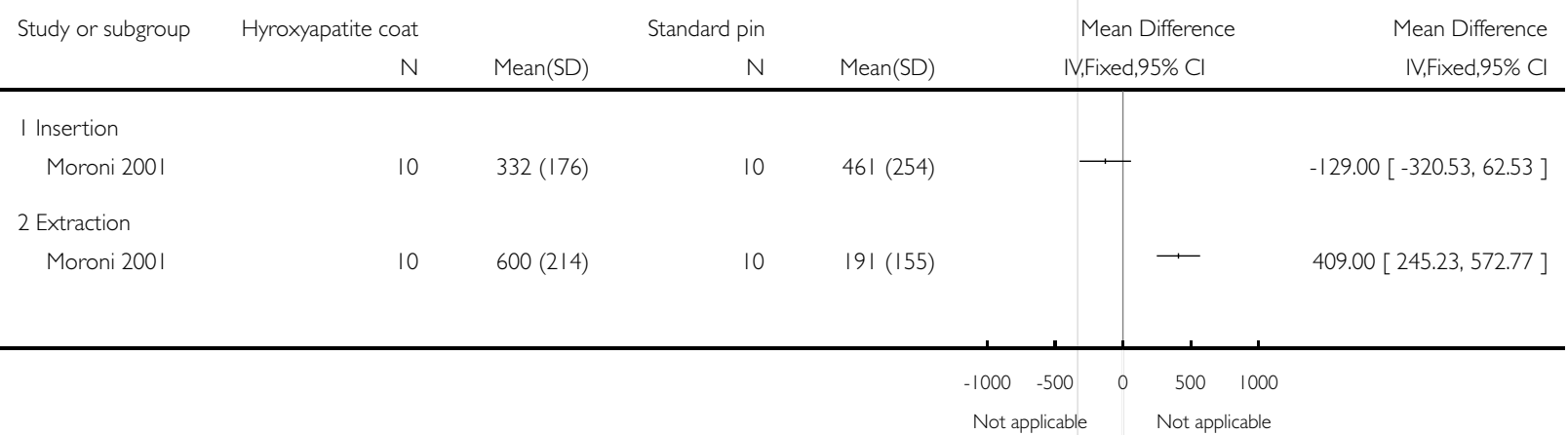




\section{Analysis 5.I. Comparison 5 Dynamic versus static fixation, Outcome I Functional gradings.}

Review: Different methods of external fixation for treating distal radial fractures in adults

Comparison: 5 Dynamic versus static fixation

Outcome: I Functional gradings

Study or subgroup Dynamic fixation $\mathrm{n} / \mathrm{N}$

\section{| Not excellent}

Sommerkamp 1994

2 Fair or poor

Sommerkamp 1994

3 Fair or poor: best case for dynamic fixation

Sommerkamp 1994

4 Fair or poor: worst case for dynamic fixation

Sommerkamp 1994

$17 / 25$

$17 / 25$

$6 / 25$

$6 / 38$

$19 / 38$
Static fixation

$\mathrm{n} / \mathrm{N}$

$10 / 25$

$2 / 25$

14/37

2/37
Risk Ratio M-H,Fixed,95\% Cl

.

$1.70[0.98,2.95]$

$3.00[0.67,13.46]$

$0.42[0.18,0.97]$

\section{Analysis 5.2. Comparison 5 Dynamic versus static fixation, Outcome 2 Mass grip strength (\% of normal} side).

Review: Different methods of external fixation for treating distal radial fractures in adults

Comparison: 5 Dynamic versus static fixation

Outcome: 2 Mass grip strength (\% of normal side)

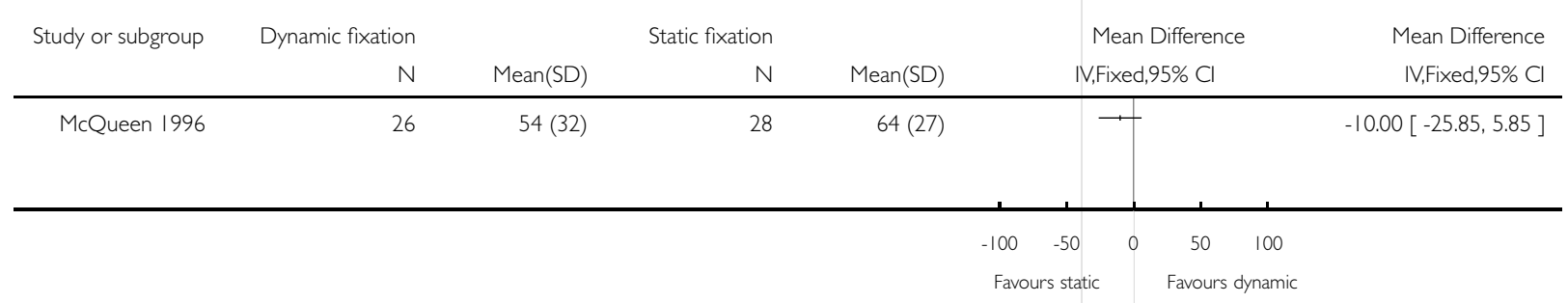


Analysis 5.3. Comparison 5 Dynamic versus static fixation, Outcome 3 Range of movement (\% of normal side).

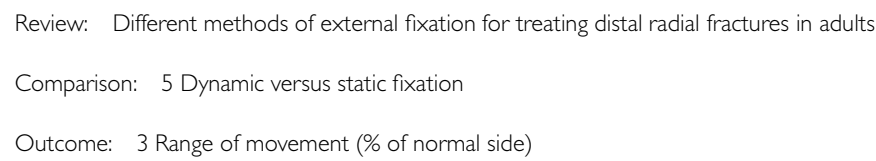

$85(10)$

28

88 (13) IV,Fixed,95\% C

\section{Analysis 5.4. Comparison 5 Dynamic versus static fixation, Outcome 4 Complications.}

Review: Different methods of external fixation for treating distal radial fractures in adults

Comparison: 5 Dynamic versus static fixation

Outcome: 4 Complications

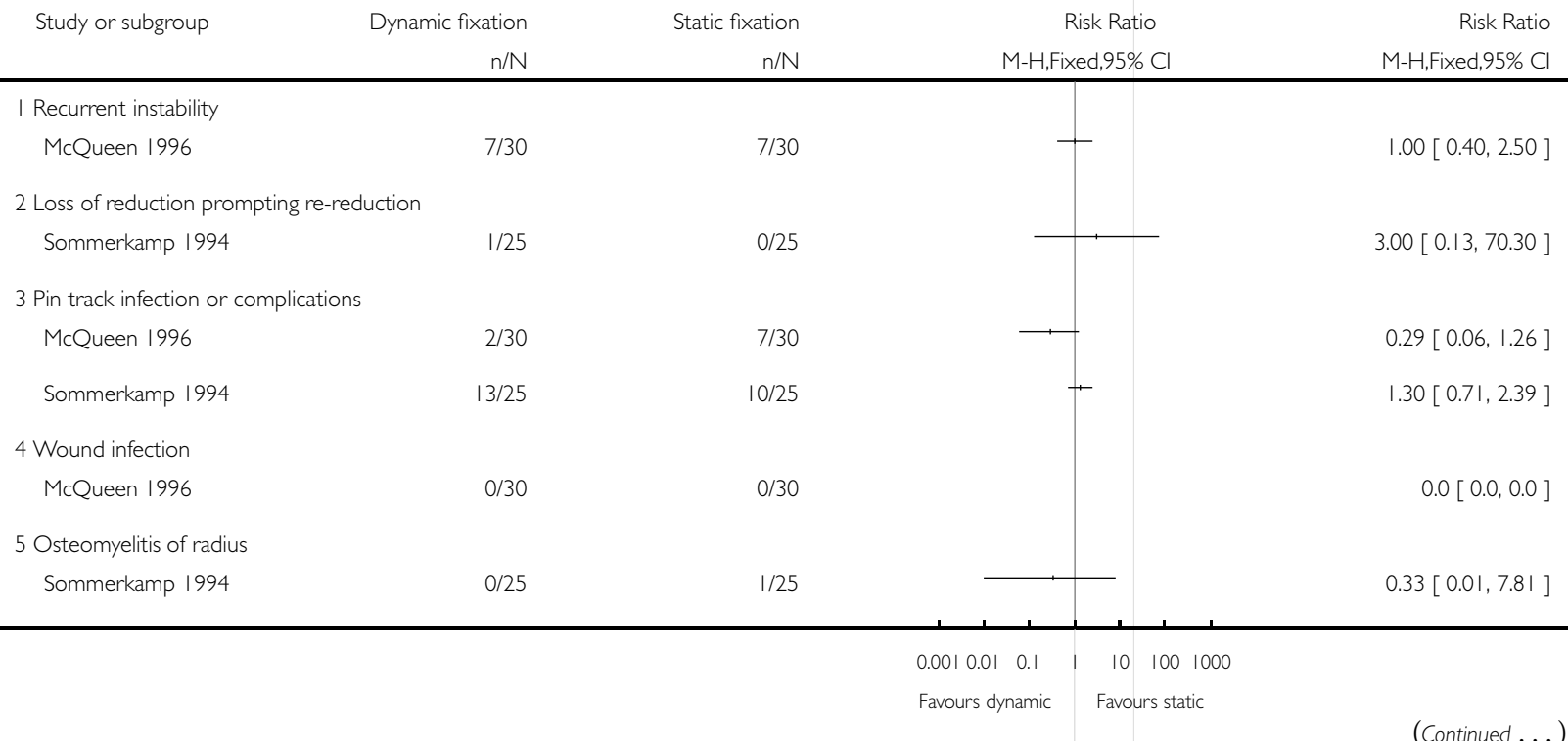




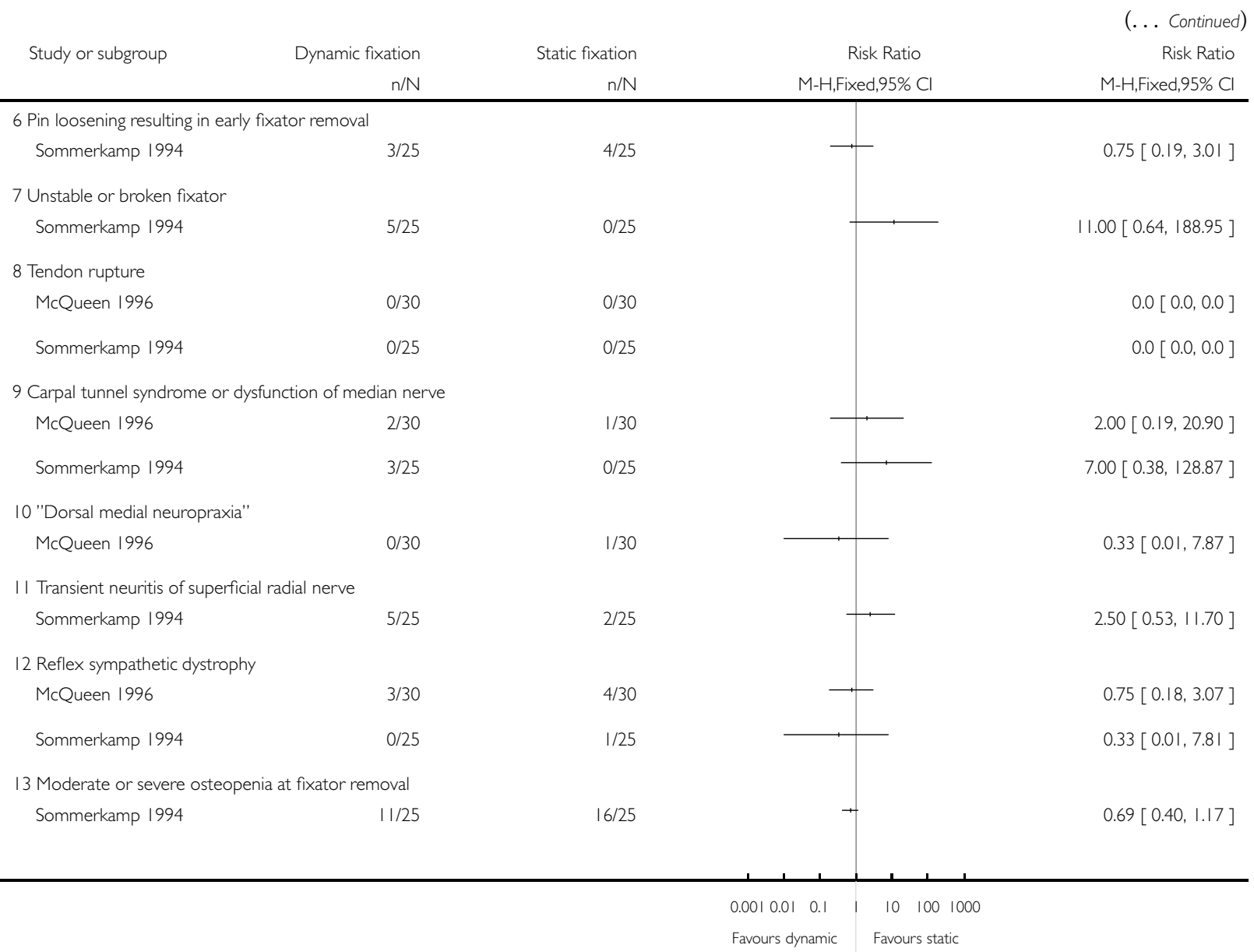

\section{Analysis 5.5. Comparison 5 Dynamic versus static fixation, Outcome 5 Anatomical displacement.}

Review: Different methods of external fixation for treating distal radial fractures in adults

Comparison: 5 Dynamic versus static fixation

Outcome: 5 Anatomical displacement

Study or subgroup Dynamic fixation Static fixation Mean Difference N Mean(SD) N $\quad$ Mean(SD) IV,Fixed,95\% Cl IV,Fixed, $95 \% \mathrm{Cl}$

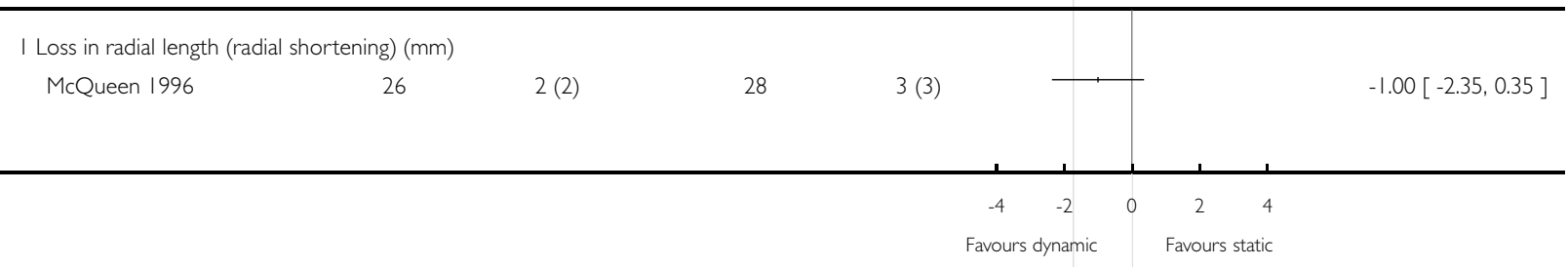




\section{Analysis 5.6. Comparison 5 Dynamic versus static fixation, Outcome 6 Anatomical measurements.}

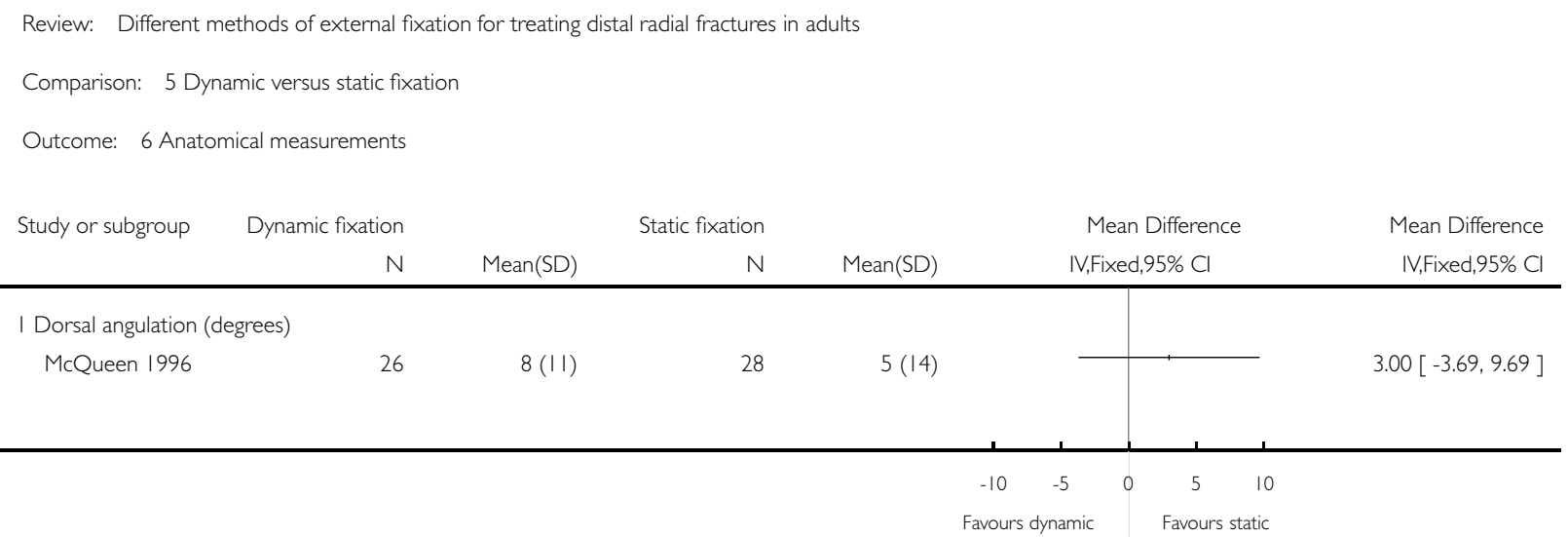

\section{Analysis 5.7. Comparison 5 Dynamic versus static fixation, Outcome 7 Deformity (structural).}

Review: Different methods of external fixation for treating distal radial fractures in adults

Comparison: 5 Dynamic versus static fixation

Outcome: 7 Deformity (structural)

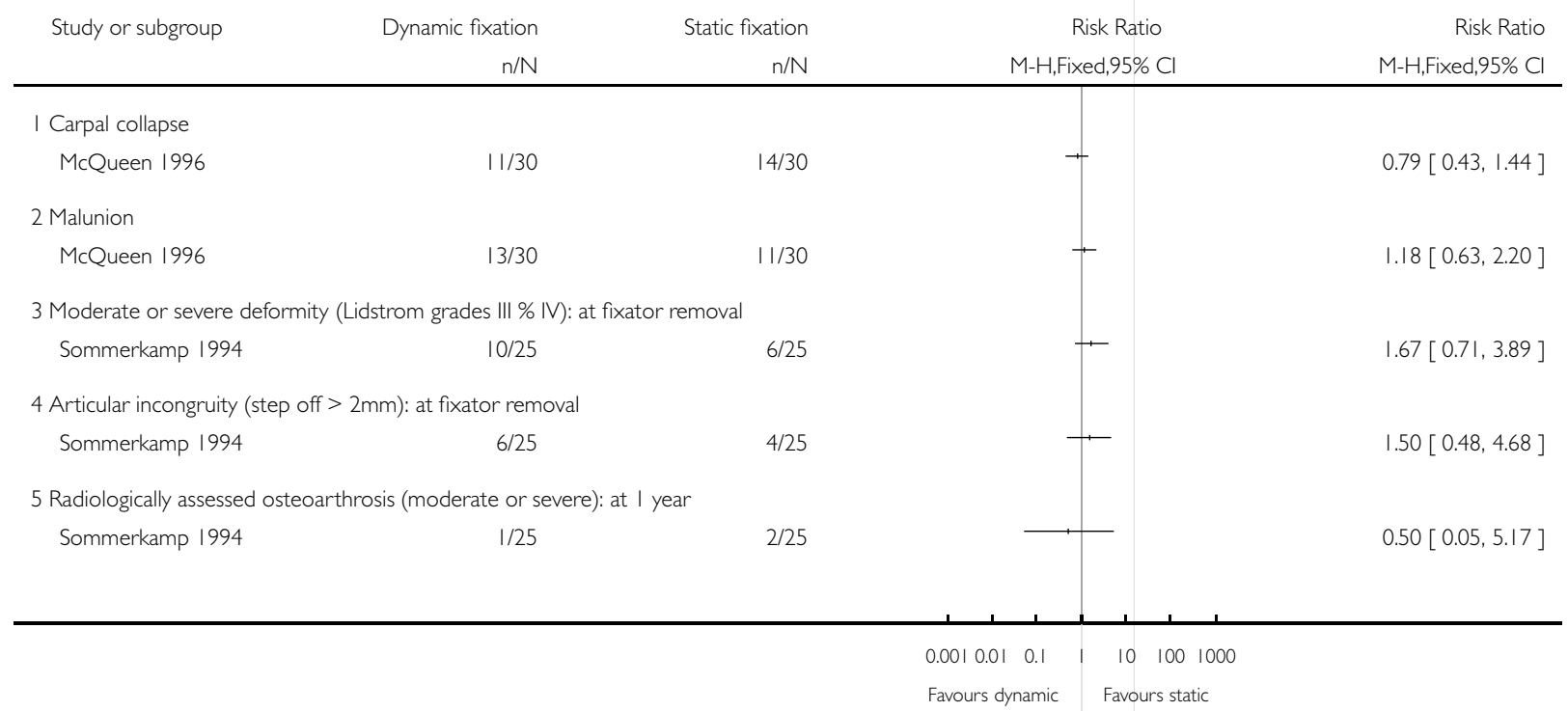




\section{A P P E N D I CES}

\section{Appendix I. Search strategy for The Cochrane Library (Wiley InterScience)}

\#1 MeSH descriptor Radius Fractures explode all trees in MeSH products \#2 MeSH descriptor Wrist Injuries explode all trees in MeSH products \#3 (\#1 OR \#2)

\#4 ((distal near radius) or (distal near radial)) in Title, Abstract or Keywords in all products \#5 (colles or smith or smiths) in Title, Abstract or Keywords in all products \#6 wrist* in Title, Abstract or Keywords in all products \#7 (\#4 OR \#5 OR \#6)

$\# 8$ fractur* in Title, Abstract or Keywords in all products \#9 (\#7 AND \#8)

\#10 (\#3 OR \#9)

\section{Appendix 2. Search strategy for MEDLINE (OVID-WEB)}

1. exp Radius Fractures/

2. Wrist Injuries/

3. (((distal adj3 (radius or radial)) or wrist or colles or smith\$2) adj3 fracture\$).ti,ab.

4. or/1-3

Appendix 3. Search strategies for CINAHL and EMBASE (OVID-WEB)

\section{CINAHL}

1. Radius Fractures/

2. Wrist Injuries/

3. or/ $1-2$

4. (((distal adj3 (radius or radial)) or wrist or colles or smith $\$ 2$ ) adj3 fracture\$).ti,ab.

5. or $/ 3-4$

6. $\exp$ Clinical Trials/

7. exp Evaluation Research/

8. exp Comparative Studies/

9. exp Crossover Design/

10. clinical trial.pt.

11. or/6-10

12. ((clinical or controlled or comparative or placebo or prospective or randomi\#ed)adj3 (trial or study)).tw.

13. (random $\$$ adj7 (allocat $\$$ or allot $\$$ or assign $\$$ or basis $\$$ or divid $\$$ or order $\$))$.tw.

14. ((singl\$ or doubl\$ or trebl\$ or tripl\$) adj7 (blind\$ or mask\$) ) .tw.

15. (cross?over\$ or (cross adj1 over\$)).tw.

16. ((allocat $\$$ or allot $\$$ or assign $\$$ or divid $\$$ ) adj3 (condition $\$$ or experiment $\$$ or intervention $\$$ or treatment $\$$ or therap $\$$ or control\$ or group\$)).tw.

17. or/12-16

18. or/ 11,17

\section{EMBASE}

1. (((distal adj3 (radius or radial)) or wrist or colles $\$ 2$ or smith $\$ 2)$ adj3 fracture $\$) . t w$.

2. Colles Fracture/ or Radius Fracture/ or Wrist Fracture/ or Wrist Injury/

3. or/1-2

4. exp Randomized Controlled trial/

5. exp Double Blind Procedure/

6. exp Single Blind Procedure/

7. $\exp$ Crossover Procedure/

8. or/4-8

9. ((clinical or controlled or comparative or placebo or prospective $\$$ or randomi\#ed)adj3 (trial or study)).tw.

10. (random \$ adj7 (allocat $\$$ or allot $\$$ or assign $\$$ or basis $\$$ or divid $\$$ or order\$)).tw.

11. ((singl\$ or doubl\$ or trebl\$ or tripl\$) adj7 (blind\$ or mask\$) ) .tw.

12. (cross?over\$ or (cross adj1 over\$)).tw.

13. ((allocat\$ or allot\$ or assign\$ or divid\$) adj3 (condition\$ or experiment $\$$ or intervention $\$$ or treatment $\$$ or therap $\$$ or control\$ or group\$)).tw.

14. or/9-13

15. or $/ 8,14$

16. Animal/ not Human/

17. 15 not 16 


\section{WHAT'S NEW}

Last assessed as up-to-date: 1 October 2007.

9 May 2008 Amended Converted to new review format.

\section{H I S T O R Y}

Protocol first published: Issue 2, 2007

Review first published: Issue 1, 2008

\section{CONTRIBUTIONS OFAUTHORS}

This review was initiated by Helen Handoll $(\mathrm{HH})$ who prepared the first draft of the protocol. This was critically reviewed by the other two authors, Jim Huntley (JH) and Rajan Madhok (RM). HH searched for trials and contacted trial authors. All three authors performed study selection. $\mathrm{HH}$ and $\mathrm{JH}$ reviewed those trials that had not been included in a previous review covering all surgical interventions. $\mathrm{HH}$ repeated her review of the other included trials that had been quality assessed previously by $\mathrm{HH}$ and $\mathrm{RM}$. $\mathrm{HH}$ completed the first draft of the review in RevMan. All versions were scrutinised by the other two authors. Helen Handoll is the guarantor of the review.

\section{DECLARATIONS OF INTEREST}

None known.

\section{SOURCES OF SUPPORT}

\section{Internal sources}

- University of Teesside, Middlesbrough, UK.

- University of Manchester, Manchester, UK. 


\section{External sources}

- No sources of support supplied

\section{NOTES}

Some of the wording in each of several sections of this review (in particular: Synopsis, Background, Methods, Discussion and Implications) is taken either entirely or in only a slightly modified form from related reviews on Percutaneous pinning for distal radial fractures in adults and External fixation versus conservative treatment for distal radial fractures in adults. This has been done to make the review self-contained and to ensure consistency between related reviews without requiring unnecessary cross-referrence by readers.

\section{N D X T E R M S}

\section{Medical Subject Headings (MeSH)}

*External Fixators; Bone Nails; Colles' Fracture [surgery]; Fracture Fixation [*methods]; Radius Fractures [classification; *surgery]; Randomized Controlled Trials as Topic; Wrist Injuries [* surgery]

\section{MeSH check words}

Adult; Female; Humans; Male 